UNIVERSIDADE DE SÃO PAULO

FACULDADE DE ECONOMIA, ADMINISTRAÇÃO E CONTABILIDADE DEPARTAMENTO DE ADMINISTRAÇÃO PROGRAMA DE PÓS-GRADUAÇÃO EM ADMINISTRAÇÃo

ALINHAMENTO ENTRE RESPONSABILIDADE SOCIAL CORPORATIVA E ESTRATÉGIA: ESTUDO DO CASO ITAÚ UNIBANCO

Simone Ruchdi Barakat

Orientador: Prof. Dr. Edison Fernandes Polo 
Prof. Dr. João Grandino Rodas

Reitor da Universidade de São Paulo

Prof. Dr. Reinaldo Guerreiro

Diretor da Faculdade de Economia, Administração e Contabilidade

Prof. Dr. Adalberto Américo Fischmann

Chefe do Departamento de Administração

Prof. Dr. Lindolfo Galvão de Albuquerque

Coordenador do Programa de Pós-Graduação em Administração 


\title{
ALINHAMENTO ENTRE RESPONSABILIDADE SOCIAL CORPORATIVA E ESTRATÉGIA: ESTUDO DO CASO ITAÚ UNIBANCO
}

\begin{abstract}
Dissertação apresentada ao Departamento de Administração da Faculdade de Economia, Administração e Ciências Contábeis da Universidade de São Paulo, como requisito para obtenção do título de Mestre em Ciências.
\end{abstract}

Orientador: Prof. Dr. Edison Fernandes Polo 
FICHA CATALOGRÁFICA

Elaborada pela Seção de Processamento Técnico do SBD/FEA/USP

Barakat, Simone Ruchdi

Alinhamento entre responsabilidade social corporativa e estratégia:

estudo do caso Itaú Unibanco / Simone Ruchdi Barakat. -- São Paulo, 2013. $149 \mathrm{p}$.

Dissertação (Mestrado) - Universidade de São Paulo, 2013.

Orientador: Edison Fernandes Polo.

1. Responsabilidade social 2. Responsabilidade social corporativa 3. Estratégia organizacional 4. Sustentabilidade 5. Setor bancário I. Universidade de São Paulo. Faculdade de Economia, Administração e Contabilidade. II. Título.

CDD -658.408 


\section{AGRADECIMENTOS}

Durante o intenso processo de realização do curso de Mestrado, conheci novas pessoas e reconheci as pessoas que estão sempre ao meu lado.

Agradeço aos meus Pais, pelo amor incondicional. Às minhas Irmãs, pelo carinho. À toda minha Família e Amigos, pelo apoio e compreensão.

Ao Prof. Dr. Edison Polo, por ter acreditado no meu potencial, me orientado e me dado liberdade para trabalhar e escolher meu tema de pesquisa.

À Profa. Bernadete de Lourdes Marinho, membro da banca de qualificação, pela ajuda, conselhos e orientações, e pelo exemplo de comprometimento ao seu trabalho.

Ao Prof. Dr. Geraldo Luciano Toledo, membro da banca de qualificação, por suas importantes contribuições para o desenvolvimento desta pesquisa, e pelo exemplo de dedicação à vida acadêmica.

Aos demais Professores da FEA, com os quais tive a oportunidade de cursar disciplinas, desenvolver pesquisas e adquirir conhecimentos.

Às minhas entrevistadas que, apesar do escasso tempo que possuem, se disponibilizaram em contribuir com esta pesquisa, fornecendo informações com inteligência e transparência. Sem a boa vontade dessas gestoras, o trabalho não teria se concretizado.

A todos os colaboradores do PPGA-FEA, da secretaria, da coordenação e da biblioteca, pelo apoio e auxílio.

À Darcy, pela revisão e contribuições ao meu trabalho.

A todos os amigos que conheci ao longo dessa jornada, com os quais pude compartilhar desafios, experiências e bons momentos, em especial, Mariana, Silvye, Patrícia, Cecília, Taiguara, Bassiro e José Guilherme.

Finalmente, agradeço a todos os professores que tive ao longo da minha vida, por contribuírem com minha formação, por meio da difícil tarefa de ensinar. 
"Não somos responsáveis apenas pelo que fazemos, mas também pelo que deixamos de fazer." Molière 


\section{RESUMO}

A Responsabilidade Social Corporativa vem ganhando destaque nas empresas, no governo, na sociedade e no campo acadêmico. Apesar disso, ainda não é possível identificar uma definição comum ou um conjunto de princípios centrais sobre o assunto. Pesquisadores ainda discutem o que significa ser socialmente responsável ou mesmo se as empresas devem ter responsabilidades sociais. Outra discussão se refere aos impactos financeiros da Responsabilidade Social Corporativa. Enquanto alguns autores afirmam que a adoção de práticas socioambientais melhora o desempenho financeiro, outros defendem que as práticas são geradoras de custos que as empresas nunca vão recuperar. Diante dessa discussão, diversos autores argumentam que o simples engajamento, em atividades consideradas socialmente responsáveis, não garante a geração de benefícios às empresas, mas, sim, se as práticas estiverem alinhadas com a Estratégia. Diante disso, o presente trabalho tem por objetivo estudar como é feito o alinhamento entre Responsabilidade Social Corporativa e Estratégia. Para atingir o objetivo proposto, foi feita a fundamentação teórica sobre o tema e a pesquisa de campo, em empresa do setor bancário, reconhecida por boas práticas de Responsabilidade Social Corporativa. O estudo é exploratório, com abordagem qualitativa, e realizado por meio da estratégia de Estudo de Caso. Os dados primários foram coletados por meio de entrevistas semiestruturadas e, os dados secundários, por meio dos relatórios de Sustentabilidade da empresa estudada e de relatórios de outras instituições que atuam com o tema no setor bancário. Os resultados mostraram que, atualmente, a empresa lida com a Responsabilidade Social Corporativa por meio do conceito de Sustentabilidade e adota uma postura proativa. Os responsáveis pelo pensamento estratégico da empresa reconhecem a importância do tema e promovem mudanças em suas estratégias, alterando visões de longo prazo, estruturas organizacionais e práticas de negócios. O processo de alinhamento do tema com a Estratégia da empresa vem sendo feito, principalmente, por meio do diálogo com stakeholders; da escolha de questões consideradas estratégicas; do envolvimento da alta gestão e das diversas áreas de negócios e do monitoramento de resultados. O estudo contribui com a formação do constructo de Responsabilidade Social Corporativa e com a distinção entre esse conceito e o de Sustentabilidade. Além disso, contribui para ampliar o conhecimento sobre as implicações estratégicas da Responsabilidade Social Corporativa e da complexa relação entre Desempenho Financeiro e Desempenho Social. A pesquisa também aponta algumas barreiras para gestão das questões socioambientais. A principal delas é a falta de conhecimento e de ferramentas práticas para lidar com o tema. 


\begin{abstract}
Corporate Social Responsibility is gaining prominence in business, in government, in society and in the academic field. Nevertheless, it is still not possible to identify a common definition or a set of core principles about the subject. Researchers still debate the means of being socially responsible or even whether companies should have social responsibilities. Another discussion refers to the financial impacts of Corporate Social Responsibility. While some authors claim that the adoption of social and environmental practices improve financial performance, others argue that the practices generates costs that businesses will never recover. Given this discussion, several authors argue that the mere engagement in activities considered socially responsible, does not guarantee the generation of benefits to businesses, but rather whether the practices are aligned with the Strategy. Thus, the present work aims to study how the alignment between Corporate Social Responsibility and Strategy is designed. To reach that goal, the theoretical foundation was made on the subject, followed by a field research in a bank company, recognized for best practices in Corporate Social Responsibility. The study is exploratory, qualitative approached and conducted by Case Study. Primary data were collected through semi-structured interviews and secondary data through the Sustainability Reports of the investigated company and through reports from other institutions that work with the theme in the banking sector. The results showed that, currently, the company deals with the Corporate Social Responsibility through the concept of Sustainability and adopts a proactive posture. Those responsible for the strategic thinking of the company recognize the importance of the issue and promote changes in their strategies, changing long-term visions, organizational structures and business practices. The process of aligning the subject with the Strategy of the company is done primarily through dialogue with stakeholders, the choice of issues considered strategic, the involvement of senior management and the various business areas and monitoring results. The study contributes to the formation of the construct of Corporate Social Responsibility and the distinction between this concept and Sustainability. Moreover, contribute to increase the knowledge about the strategic implications of Corporate Social Responsibility and the complex relationship between Financial Performance and Social Performance. The survey also indicates some barriers to the management of social and environmental issues. The main one is the lack of knowledge and practical tools to deal with the issue.
\end{abstract}




\section{SUMÁRIO}

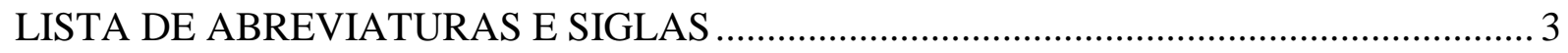

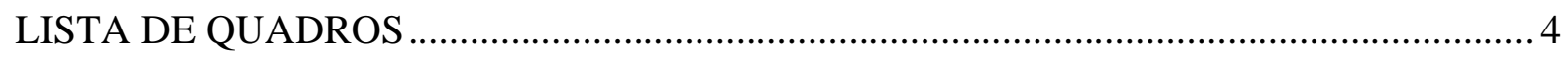

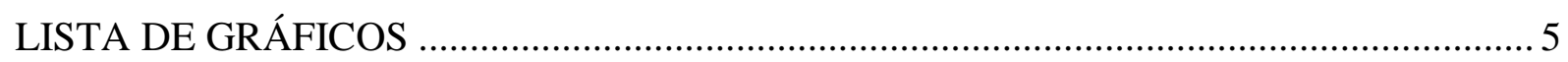

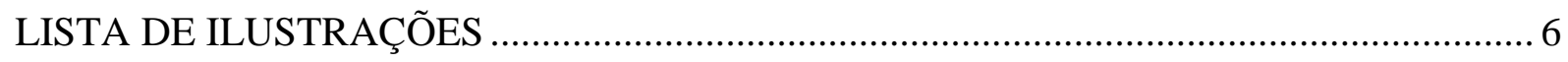

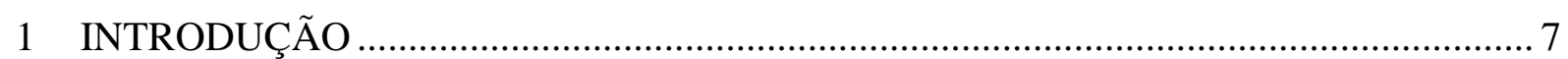

1.1 Definição da Situação Problema ............................................................................. 9

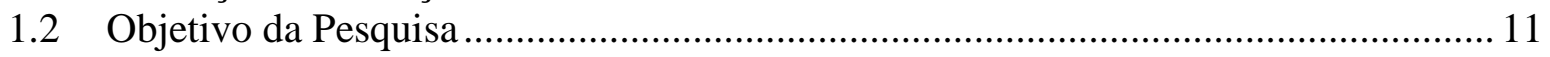

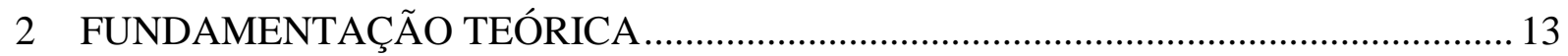

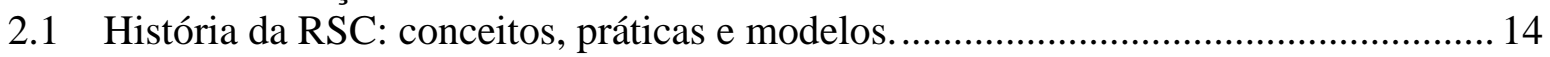

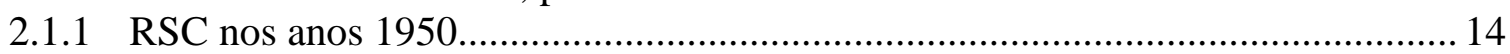

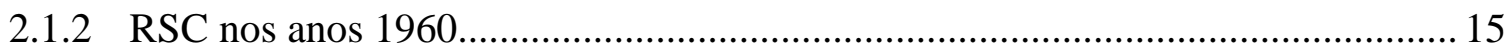

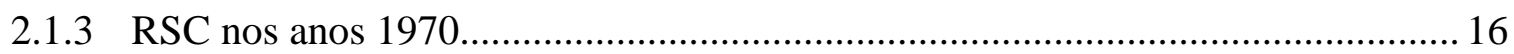

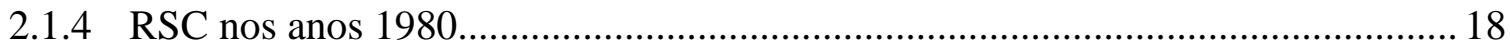

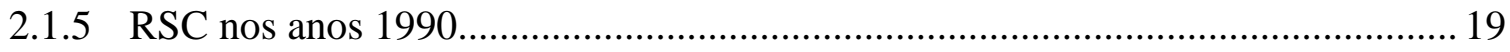

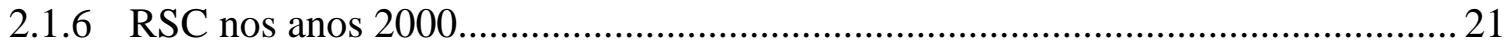

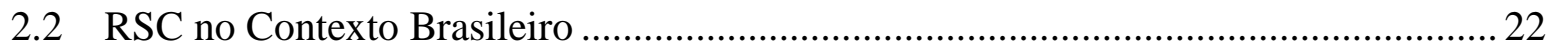

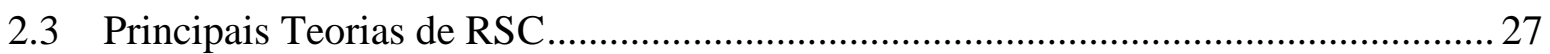

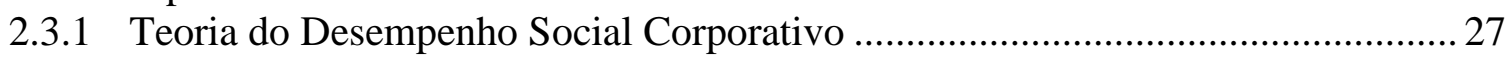

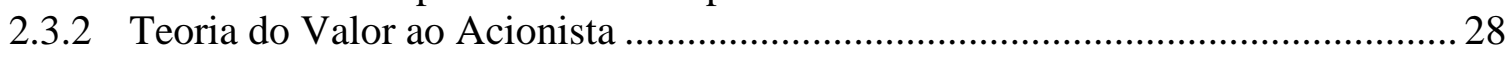

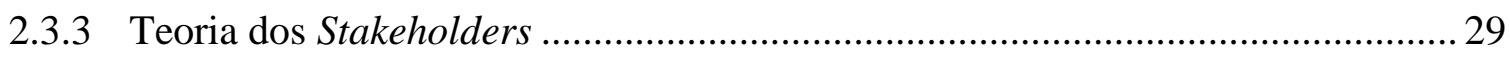

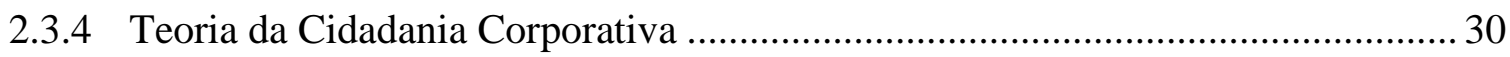

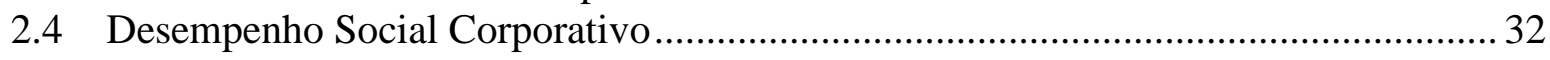

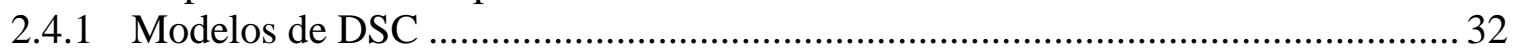

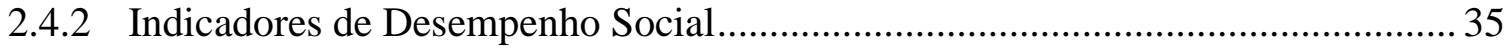

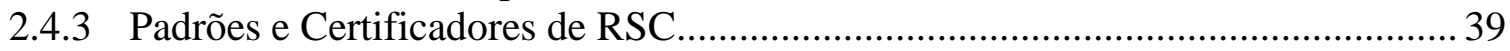

2.4.4 Desempenho Social Corporativo (DSC) versus Desempenho Financeiro

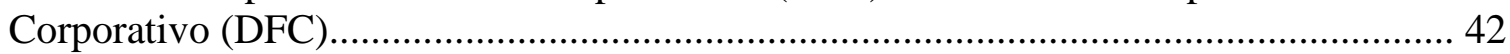

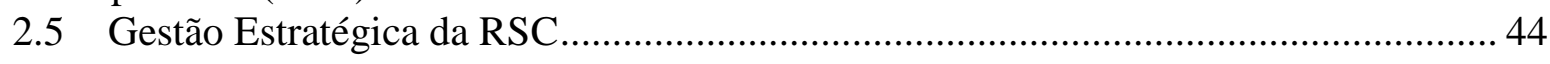

2.5.1 Responsabilidade Social Corporativa Estratégica............................................... 44

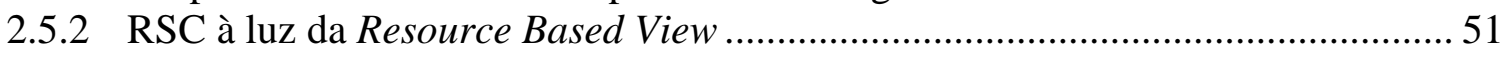

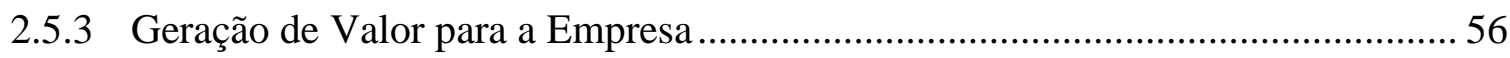

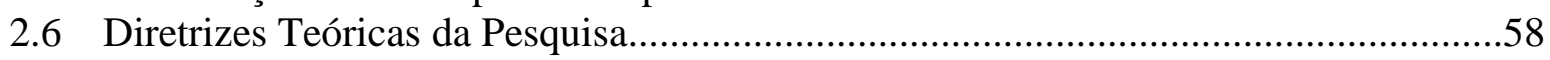

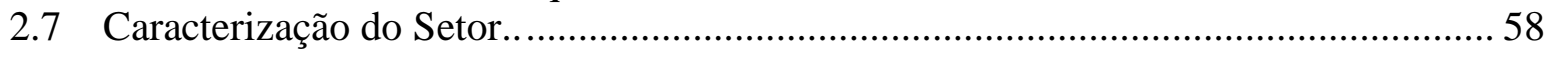

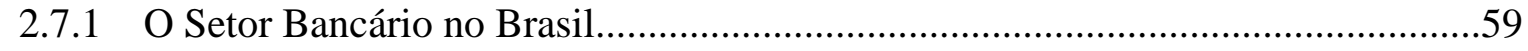

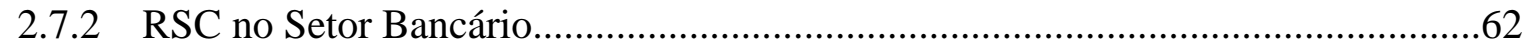

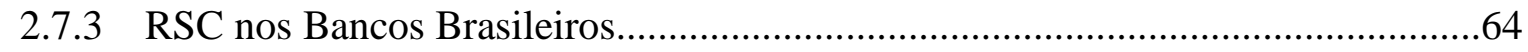

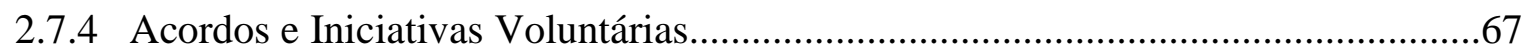

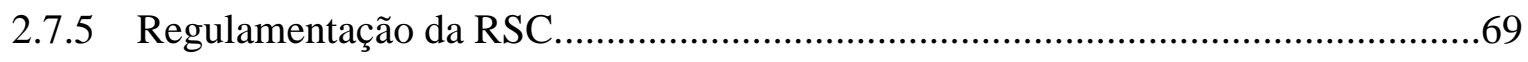

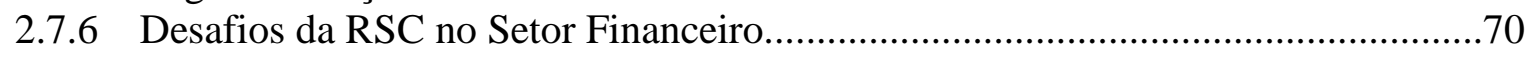

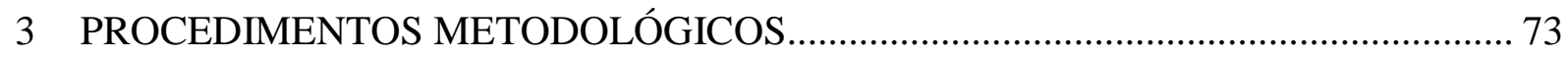

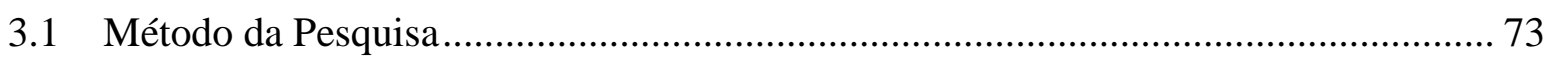

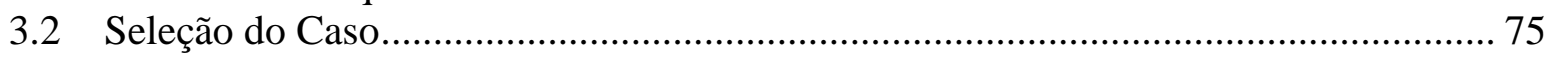

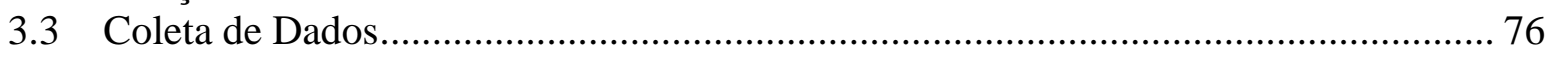

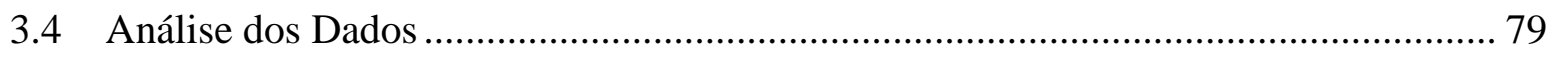




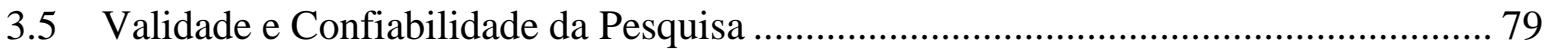

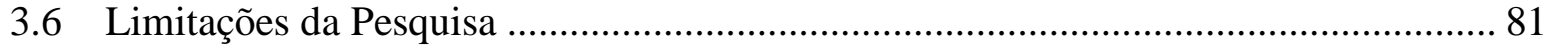

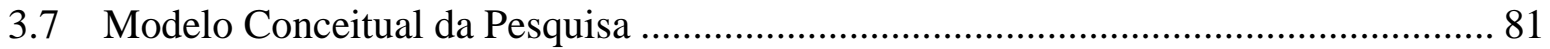

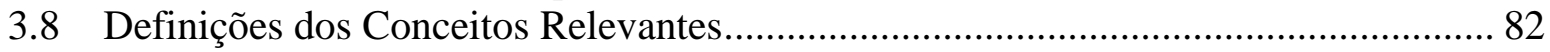

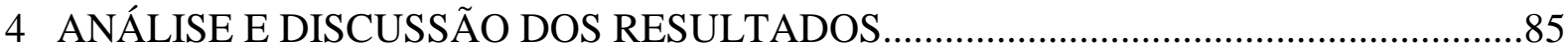

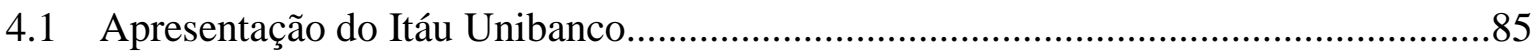

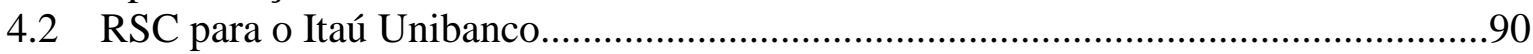

4.3 Alinhamento entre RSC e Estratégia Organizacional................................................92

4.3.1 Processo de Elaboração da Nova Visão e Cultura ................................................92

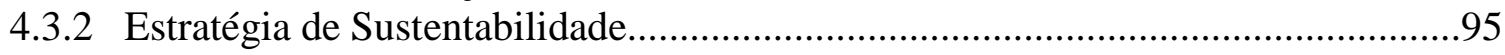

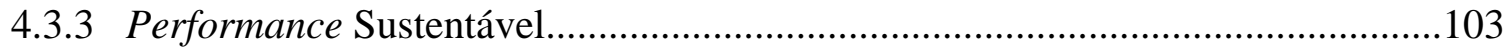

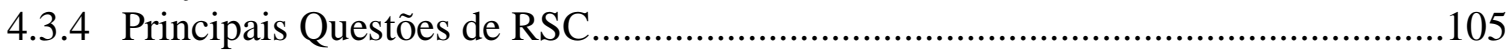

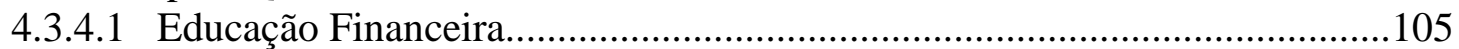

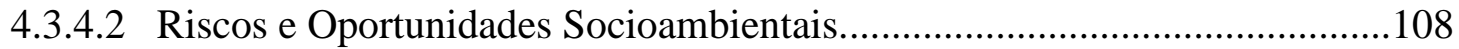

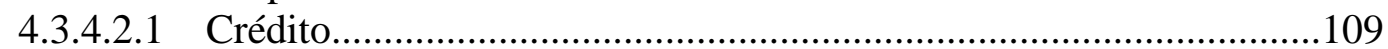

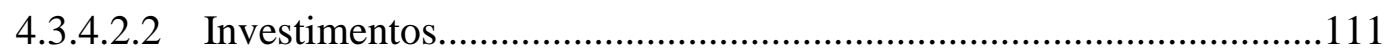

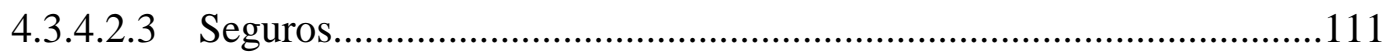

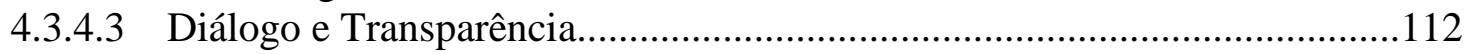

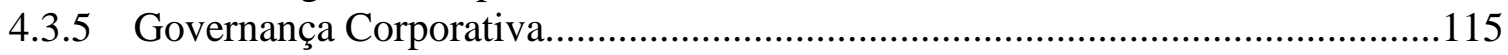

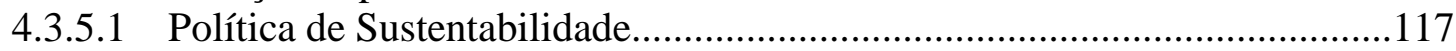

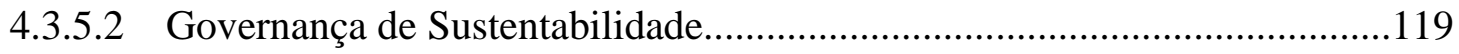

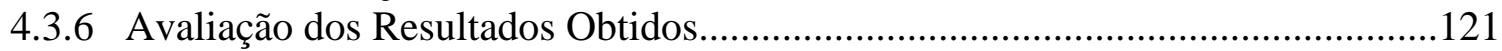

4.3.7 Compromissos e Pactos Voluntários....................................................................122

4.3.8 Prêmios e Reconhecimentos Recebidos.............................................................124

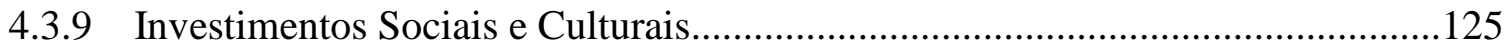

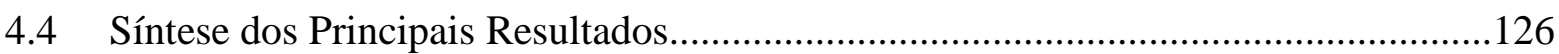

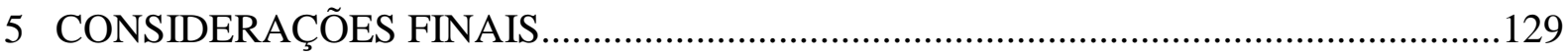

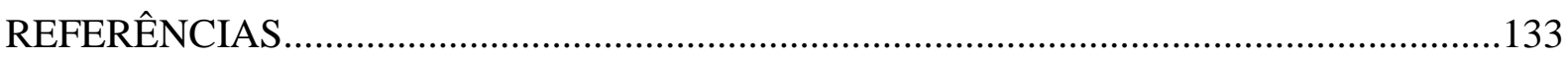

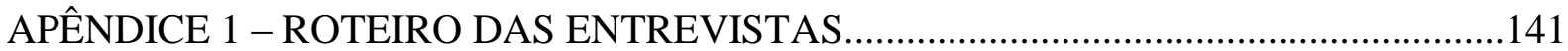




\section{LISTA DE ABREVIATURAS E SIGLAS}

ABRASCA: Associação Brasileira de Companhias Abertas

ABNT: Associação Brasileira de Normas Técnicas

APIMEC: Associação dos Analistas e Profissionais de Investimento do Mercado de Capitais BCB: Banco Central do Brasil

BM\&FBOVESPA: Bolsa de Valores de São Paulo

BNDES: Banco Nacional de Desenvolvimento Econômico e Social

CERES: Coalition for Environmentally Responsible Economies

CDP: Carbon Disclosure Project

CONAR: Conselho Nacional de Autorregulamentação Publicitária

DSC: Desempenho Social Corporativo

DFC: Desempenho Financeiro Corporativo

DJSI: Dow Jones Sustainability Index

FBDS: Federação Brasileira de Desenvolvimento Sustentável

FEBRABAN: Federação Brasileira de Bancos

GHG: Greenhouse Gas

GIFE: Grupo de Institutos, Fundações e Empresas

GEE: Gases de Efeito Estufa

GRI: Global Reporting Initiative

GVCes: Centro de Estudos em Sustentabilidade da Fundação Getúlio Vargas

IBASE: Instituto Brasileiro de Análises Sociais e Econômicas

IBOVESPA: Índice da Bolsa de Valores de São Paulo

IFC: Internacional Finance Corporation

IPEA: Instituto de Pesquisas Econômicas Aplicadas

ISE: Índice de Sustentabilidade Empresarial

ISO: International Organization for Standardization

NRBV: Natural Resource Based View

OECD: Organisation for Economic Co-operation and Development

ONGs: Organizações não governamentais

ONU: Organização das Nações Unidas

PRI: Principles for Responsible Investments

PNBE: Pensamento Nacional das Bases Empresariais

RBV: Resource Based View

ROE: Return on Equity

RSC: Responsabilidade Social Corporativa

SFN: Sistema Financeiro Nacional

SRI: Socially Responsible Investments

SUMOC: Superintendência da Moeda e do Crédito

TBL: Triple Bottom Line

UNEP: Programa das Nações Unidas para o Meio Ambiente

UNEP-FI: Programa das Nações Unidas para o Meio Ambiente em Instituições Financeiras

WCED: World Commission on Environment and Development 


\section{LISTA DE QUADROS}

Quadro 1 - Atividades de RSC adotadas pelas maiores empresas na década de 1970............17

Quadro 2 - Principais teorias de RSC.....................................................................................

Quadro 3 - Orientação da empresa para seus stakeholders....................................................33

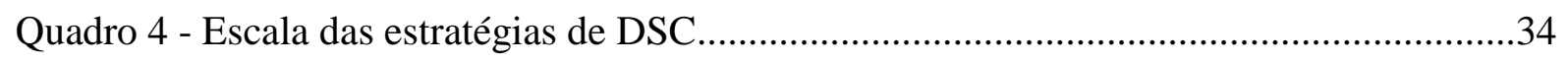

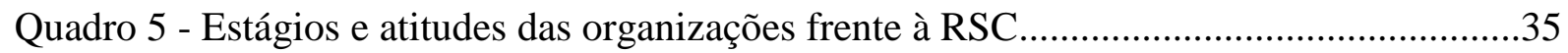

Quadro 6 - Envolvimento da empresa na sociedade: abordagem estratégica..........................48

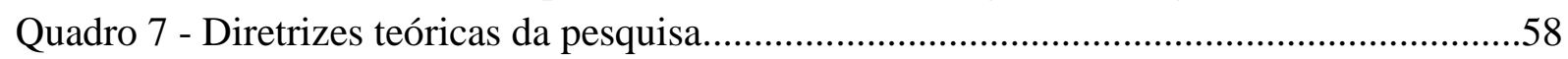

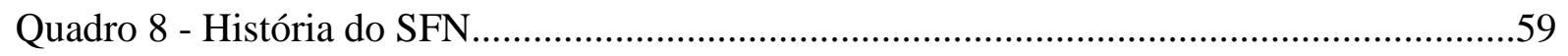

Quadro 9 - Número de bancos públicos e privados no país, de 1997 a 2011 ...........................60

Quadro 10 - Sustentabilidade nas instituições financeiras atuantes no Brasil...........................65

Quadro 11 - Gestoras entrevistadas na pesquisa de campo...................................................78

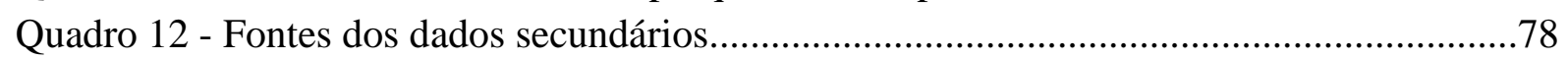

Quadro 13 - Testes que garantem a qualidade da pesquisa social empírica.............................80

Quadro 14 - Principais indicadores financeiros da instituição em 2012 .................................88

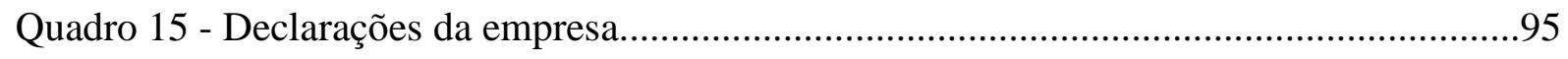

Quadro 16 - Categorização da análise socioambiental........................................................110

Quadro 17 - Histórico das práticas de governança............................................................118

Quadro 18 - Adesão do Itaú Unibanco às principais iniciativas voluntárias..........................123

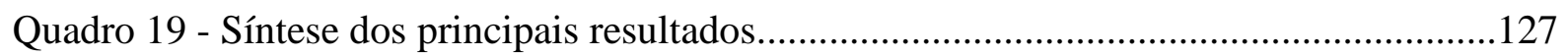




\section{LISTA DE GRÁFICOS}

Gráfico 1 - Percepção dos empresários sobre sua atuação na área social..............................26

Gráfico 2 - Motivos pelos quais as empresas realizam ações sociais, em 2000 e 2004..........26

Gráfico 3 - Participação dos dez maiores bancos atuantes no Brasil em 2011........................61

Gráfico 4 - Motivações para bancos incorporarem a sustentabilidade...................................63

Gráfico 5 - Benefícios da incorporação da sustentabilidade..................................................63

Gráfico 6 - Barreiras para implementar sistemas de gestão socioambiental.............................71

Gráfico 7 - Composição do lucro líquido recorrente do Itaú Unibanco em 2012 ....................90 


\section{LISTA DE ILUSTRAÇÕES}

Ilustração 1 - Pirâmide da responsabilidade social..................................................................18

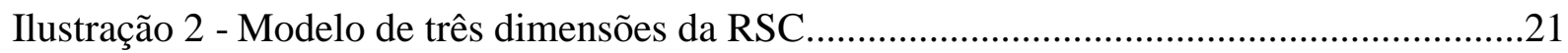

Ilustração 3 - Princípios para elaboração do relatório de sustentabilidade/RSC de acordo com

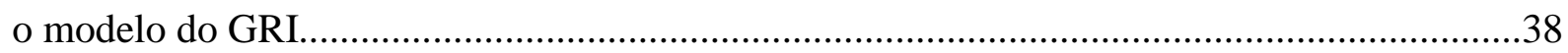

Ilustração 4 - Convergência de interesse comercial e social.................................................47

Ilustração 5 - Visão integrada da estratégia corporativa e social............................................50

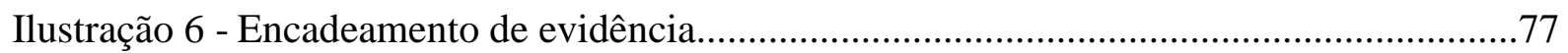

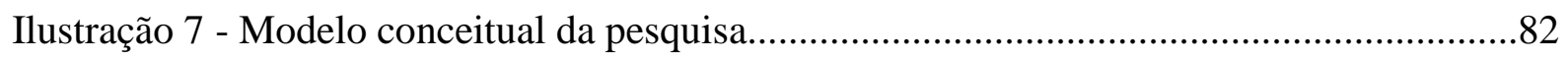

Ilustração 8 - Mudança da visão do Itaú Unibanco..............................................................94

Ilustração 9 - Processo de construção do Mapa de Sustentabilidade........................................99

Ilustração 10 - Mudança no posicionamento da empresa com relação à sustentabilidade......100

Ilustração 11 - Mapa de Sustentabilidade do Itaú Unibanco..................................................102

Ilustração 12 - Figura representativa da performance sustentável.........................................103

Ilustração 13 - Governança de Sustentabilidade em 2011 e 2012 ..........................................120 


\section{INTRODUÇÃO}

No início do século XX, a gestão das empresas estava direcionada, basicamente, para a produção, devido à pouca concorrência existente na época. Com a queda de barreiras comerciais e a integração dos mercados, a competição entre as empresas se acirrou. Foi preciso mudar as estratégias de negócio e incorporar questões como qualidade, marca, inovação e outros atributos que pudessem diferenciar as empresas e seus produtos. Entretanto, questões relativas ao comportamento socialmente responsável das empresas ainda não estavam em pauta.

Somente a partir da segunda metade do século passado, cresceu a percepção entre os consumidores dos efeitos negativos sobre o meio ambiente e a qualidade de vida das pessoas que certas atividades empresariais podem causar. Nos anos 1960, grupos pacifistas que protestavam contra o envolvimento dos Estados Unidos na Guerra do Vietnã repudiaram as empresas fabricantes do "napalm" e do desfolhante conhecido como "agente laranja", armas químicas utilizadas pelo exército norte-americano, que provocavam grandes danos em populações civis. Nos anos 70, o ativismo pela atuação responsável das empresas ganhou ímpeto com as críticas mundiais ao regime do Apartheid na África do Sul e com os riscos da energia nuclear. (MARCONDES; BACARJI, 2010)

Com a expansão do ambiente de negócios, que se intensificou nos anos 80, criaram-se, junto de um novo universo de oportunidades, muitas distorções. Empresas que operavam nos mercados mais desenvolvidos dos Estados Unidos e da Europa passaram a distribuir sua produção pelo chamado Terceiro Mundo, onde trabalhadores pobres, com pouca segurança e com menos direitos, produziam por salários menores. Além disso, países com legislação e controle menos rígidos atraíram empresas que desejavam se afastar dos rigores da lei e da pressão da sociedade (MARCONDES; BACARJI, 2010). Em 1984, sob esse pano de fundo de pouca regulamentação, aconteceu a tragédia da cidade indiana de Bhopal, onde o vazamento de gás tóxico de uma unidade da empresa Union Carbide matou quatro mil pessoas e deixou sequelas em 200 mil (CARROLL, 2008).

Diante dos impactos, cada vez mais evidentes, de certas atividades empresariais, os consumidores passaram a exigir das empresas a adoção de condutas mais éticas, transparentes 
e socialmente responsáveis. Consequentemente, as mesmas passaram a se preocupar, cada dia mais, com a responsabilidade em suas atividades. Esse novo cenário está profundamente relacionado com o princípio que norteia o chamado "desenvolvimento sustentável", que ganhou notoriedade após a publicação do relatório Brundtland, realizado pela World Commission on Environment and Development (WCED), da Organização das Nações Unidas (ONU), em 1987. O relatório destaca que desenvolvimento sustentável é atender às necessidades da geração atual sem comprometer a possibilidade das gerações futuras suprirem suas próprias necessidades.

Desde então, é notável a crescente atenção dada à Responsabilidade Social Corporativa (RSC). Houve uma proliferação de consultorias e serviços dedicados ao tema, bem como um número crescente de padrões e certificadores que visam à institucionalização das práticas de RSC, como a ISO14000 - certificado que atesta a gestão ambiental das empresas - e o SA8000 - que visa aprimorar as condições de trabalho. Organizações foram fundadas para estabelecer padrões e comparar o comportamento das empresas, como a Global Reporting Initiative (GRI), em 1997, que criou padrões mundiais para elaboração de relatórios de responsabilidade social e sustentabilidade e tem seu modelo utilizado por mais de 1000 empresas, sendo 60 delas brasileiras.

De acordo com pesquisa realizada pela empresa de consultoria KPMG (2011), 95\% das 250 maiores empresas mundiais emitem relatórios sobre suas atividades de responsabilidade corporativa. As organizações europeias, tradicionalmente, são as que mais reportam suas atividades e, ainda de acordo com os dados da pesquisa, $71 \%$ das empresas europeias investigadas reportam suas práticas de responsabilidade social. Na América Latina e América do Norte, essa proporção é de 69\%, na África e Oriente Médio é de 61\%, e na região da Ásia-Pacífico, 49\%. Destacam-se ainda os números evidenciados no Brasil, onde $88 \%$ das empresas estudadas divulgam dados sobre responsabilidade corporativa para os mercados.

Outro indicador da institucionalização da RSC é o surgimento dos chamados investimentos socialmente responsáveis ou Socially Responsible Investments (SRI), a fim de atender a um crescente número de investidores que desejam aplicar seus recursos em empresas consideradas socialmente responsáveis. Em fevereiro de 2012, o valor dos ativos de SRI, no Brasil, correspondia a $\mathrm{R} \$ 742$ milhões, representando um crescimento de 55,34\% em relação a 2006. Nos Estados Unidos, em 1995, o valor dos ativos de SRI correspondia a US\$639 
bilhões e, em 2010, passou para US\$ 3,07 trilhões, representando um aumento de 380\% (BM\&FBOVESPA, 2012). Diante da crescente demanda pelos SRI, foram criados índices de ações com o objetivo de mostrar o desempenho de mercado de carteiras formadas por empresas que adotam os princípios de responsabilidade social e gestão sustentável. O primeiro grande grupo a incorporar esse conceito em seus produtos foi o Dow Jones, nos EUA, com a criação do Dow Jones Sustainability Index (DJSI), em 1999. Em países emergentes, o primeiro índice de sustentabilidade empresarial foi criado, em 2003, pela Johannesburg Stock Exchange, na África do Sul. E, no Brasil, essa tendência teve início em 2005 com a criação do Índice de Sustentabilidade Empresarial (ISE), pela Bolsa de Valores de São Paulo (BM\&FBOVESPA).

$\mathrm{O}$ crescente destaque dado à RSC também se reflete no campo acadêmico. Um número considerável de contribuições tem sido publicado nos chamados periódicos da "corrente principal", como Academy of Management Journal, Academy of Management Review, California Management Review e Harvard Business Review. Da mesma forma, houve um número considerável de edições especiais dedicadas à RSC, como no Journal of International Business Studies ou Journal of Management Studies. Além disso, a aceitação pela "corrente principal" da RSC como um campo do conhecimento acadêmico não se aplica somente aos periódicos americanos, mas também a algumas das revistas de teoria das organizações mais críticas da Europa, como Organization Studies e Organization, que começaram a publicar mais pesquisas relacionadas ao tema (LOCKETT et al., 2006). Destaca-se, também, o surgimento de conferências e sociedades científicas interessadas no assunto. Entre as mais antigas, pode-se citar a Social Issues in Management Division da Academy of Management, formada em 1976, e a Society for Business Ethics, criada em 1980, que possuem encontros anuais e reúnem cientistas de todo o mundo (CRANE et al., 2008).

\subsection{Definição da Situação Problema}

Apesar da crescente evidência do tema da RSC, não é possível identificar uma definição comum ou um conjunto de princípios centrais sobre o assunto. Pesquisadores ainda discutem o que significa ser socialmente responsável ou mesmo se as empresas devem ter responsabilidades sociais (CARROLL, 2008; CRANE et al., 2008). Há tantas definições para o termo que até agora não existe um consenso para o seu significado (McWILLIAMS et al., 
2006, NASCIMENTO et al., 2008). Carrol (2008) fornece uma extensa visão de algumas dessas definições, as quais mostram uma grande variedade de pressupostos sobre o que deve abranger a responsabilidade das empresas. Enquanto Friedman (1970) afirmava que "a única responsabilidade social da empresa é aumentar seus lucros”, Davis (1973) argumentou que RSC requer considerações sobre questões que vão além dos requisitos econômicos, técnicos e legais da firma.

Outro debate se refere aos impactos econômicos da RSC. Por um lado, alguns autores afirmam que a adoção de práticas socialmente responsáveis melhora o desempenho econômico e, por outro lado, há a visão de que as práticas são geradoras de custos que as empresas nunca vão recuperar, representando desvios financeiros (RUSSO; FOUTS, 1997). Essa questão tem dominado a pesquisa em RSC nos últimos trinta anos (CRANE et al., 2008). Diversos estudos foram feitos com o objetivo de encontrar uma relação positiva entre Desempenho Social e Desempenho Financeiro, o que demonstraria benefícios para as empresas ao se engajarem neste tipo de atividade (McWILLIAMS; SIEGEL, 2011), porém, os resultados obtidos são ambíguos. Enquanto algumas pesquisas encontraram uma relação positiva entre RSC e Desempenho Financeiro, outras não observaram nenhuma relação e, ainda, outras mostraram uma relação negativa (McWILLIAMS et al., 2006; CRANE et al., 2008). A inconsistência desses achados pode estar relacionada à inconsistência na própria definição de RSC e nas diferentes formas usadas para medir o desempenho empresarial (McWILLIAMS et al., 2006; MADARIAGA; CREMADES, 2010).

A expectativa de encontrar uma relação positiva entre Desempenho Social e Desempenho Financeiro baseia-se no argumento que conecta as práticas empresariais "responsáveis" à criação de valor para o acionista a longo prazo. Espera-se que as empresas consideradas responsáveis desfrutem de acesso mais rápido e barato ao crédito, de menores custos de seguro, de bom clima organizacional, e também atraiam e retenham os melhores talentos. Espera-se também que conquistem maior lealdade do consumidor e, com isso, valorizem a imagem institucional e, ainda, reduzam riscos e passivos socioambientais, diminuam as chances de conflitos e garantam a licença social para operar. (MARCONDES; BACARJI, 2010; BRANCO; RODRIGUES, 2006; BACKHAUS et al., 2002; FOMBRUN et al., 2000)

Porém, diversos autores (HART, 1995, 1997; PORTER; KRAMER, 2002, 2006; McWILLIAMS; SIEGEL, 2000; McWILLIAMS et al., 2006, 2011; HUSTED; SALAZAR, 
2006) argumentam que o simples engajamento das empresas em atividades consideradas socialmente responsáveis não garante a geração de benefícios às empresas. Para esses autores, a RSC somente leva à criação de valor para a empresa, se estiver alinhada com a Estratégia Organizacional.

Diante dessa discussão, o presente estudo busca responder a seguinte questão de pesquisa: Como é feito o alinhamento entre RSC e a Estratégia Organizacional?

\subsection{Objetivo da Pesquisa}

De forma a responder a questão proposta, estabeleceu-se como objetivo da pesquisa: Entender o processo de alinhamento entre a RSC e a Estratégia Organizacional.

Para atingir o objetivo proposto, primeiramente, foi feita a revisão da literatura existente sobre o tema. O levantamento, que alicerça o estudo, baseou-se nos seguintes tópicos principais: a) História da RSC: conceitos, práticas e modelos; b) Principais Teorias de RSC; c) Desempenho Social Corporativo; d) Gestão Estratégica da RSC.

Após a realização da fundamentação teórica, partiu-se para a pesquisa de campo em empresa brasileira do setor bancário, mundialmente reconhecida por boas práticas de RSC, com os objetivos de: a) Identificar qual o entendimento sobre RSC adotado pela empresa estudada; b) Identificar que práticas de RSC são realizadas pela empresa e como são escolhidas; c) Descrever como é feito o alinhamento entre a RSC e a Estratégia da empresa. 


\section{FUNDAMENTAÇÃO TEÓRICA}

O campo do conhecimento que a RSC representa é amplo e diverso, abrangendo debates a partir de muitas perspectivas, disciplinas e posições ideológicas. Mesmo em Administração de Empresas, a RSC é abordada a partir de muitas subdisciplinas como Estratégia, Marketing, Contabilidade, Operações, Comportamento Organizacional e outras. Os trabalhos em RSC têm, também, cada vez mais, se originado de outras fontes, como Direito, Economia, Ciências Políticas, Geografia, Sociologia, História, entre outras. Isso traz à literatura uma diversidade de perspectivas teóricas, abordagens conceituais e tradições empíricas que não levam a um consenso sobre conceitos críticos, porém, enriquecem e inspiram o debate. (CRANE et al., 2008)

A RSC é ainda considerada um campo de pesquisa em desenvolvimento. DeBakker et al. (2005) realizaram uma análise bibliométrica de mais de 500 artigos sobre RSC publicados nos últimos 35 anos e concluíram que não é possível evidenciar uma operacionalização dos conceitos gerais centrais. De acordo com DeBakker et al. (2005), o desenvolvimento do constructo de RSC aconteceu de uma incerteza conceitual que teve três fases distintas: progressão, variedade e normativismo. A progressão é expressa pelo desenvolvimento a partir da teoria empiricamente testada. A variedade explica que o conceito alterna seu significado de acordo com o contexto ou com a relação que estabelece com temas complementares. E o normativismo se refere ao caráter prescritivo encontrado nos trabalhos do campo da RSC. Além disso, esses autores consideram que a evolução da literatura sobre RSC é dificultada pela introdução contínua de novos constructos e que o campo da RSC se tornou firmemente ligado às Ciências da Administração. (DeBAKKER et al., 2005)

Da mesma forma, Lockett et al. (2006, p. 113) concluíram, a partir de um estudo sobre a literatura de RSC, em um período de dez anos, que o conhecimento sobre o tema pode melhor ser descrito como "em estado contínuo de emergência". Segundo esses autores, o campo não é caracterizado pelo domínio de uma abordagem teórica, método e pressupostos particulares, é um campo sem um "paradigma".

De acordo com Kuhn (1975, p.13), paradigmas são “as realizações científicas universalmente reconhecidas que, durante algum tempo, fornecem problemas e soluções modelares para uma 
comunidade de praticantes de uma ciência". Na ausência de um paradigma ou de algum candidato a paradigma, todos os fatos que possivelmente sejam pertinentes ao desenvolvimento de determinada ciência têm a probabilidade de parecerem igualmente relevantes (KUHN, 1975).

Diante de diversas perspectivas e teorias que abordam a RSC, o presente estudo buscou fundamentação nos trabalhos realizados na Área de Administração de Empresas, com abordagem da linha de Estratégia. Primeiramente, são apresentados os principais conceitos, práticas e modelos, abordados na história da RSC. Depois, apresentam-se as principais teorias de RSC existentes na literatura e adota-se a Teoria do Desempenho Social Corporativo, como fundamentação para o trabalho. E, finalmente, apresenta-se a gestão estratégica da RSC.

\subsection{História da RSC: conceitos, práticas e modelos.}

\subsubsection{RSC nos anos 1950}

As discussões acerca da RSC cresceram nas últimas duas décadas, porém a literatura sobre o tema data, pelo menos, da década de 1950. As questões centrais da RSC, tais como: para que serve um negócio e qual a contribuição deste para a sociedade, são tão antigas quanto os negócios em si.

A publicação do livro Social Responsibilities of the Businessman, de Howard R. Bowen, em 1953, é considerada o marco da literatura moderna sobre o assunto. O autor acreditava que as maiores empresas de sua época eram centros de poder e decisões e que suas ações impactavam as vidas dos cidadãos de diversas formas. Ele questionou: Quais responsabilidades se espera que os homens de negócios tenham com a sociedade? Além disso, estabeleceu a definição inicial da responsabilidade social do empresário, afirmando que esta se refere às obrigações dos homens de negócios em adotar políticas, tomar decisões ou seguir linhas de ações que são desejáveis em termos de objetivos e valores da nossa sociedade. O autor estava preocupado, principalmente, com a doutrina da responsabilidade social, porém pode-se identificar como ele iniciou a discussão moderna sobre o assunto. $\mathrm{O}$ autor afirma, por exemplo, que a responsabilidade social não é uma panaceia para todos os problemas sociais, 
porém ela contém uma verdade importante que pode guiar os negócios no futuro. (CARROLL, 2008)

Em 1958, Theodore Levitt escreveu The Dangers of Social Responsibility, artigo publicado na Harvard Business Review, em que afirma que o trabalho do governo não são os negócios e o trabalho dos negócios não é o governo. Milton Friedman (1970) expressou o mesmo sentimento e adicionou que a simples existência da RSC mostra um problema de agência nas organizações. O relacionamento de agência é um contrato no qual uma ou mais pessoas (principal) engajam outra pessoa (agente) para desempenhar alguma tarefa em seu favor, envolvendo a delegação de autoridade para a tomada de decisão. Dessa forma, se ambas as partes agem tendo em vista a maximização de suas utilidades pessoais, a Teoria de Agência afirma que existe uma boa razão para acreditar que o agente não agirá sempre no melhor interesse do principal. O problema de agência ocorre quando os gestores tomam decisões com o intuito de maximizar sua utilidade pessoal e não a riqueza dos acionistas. Os custos de agência são custos em que os acionistas incorrem para alinhar os interesses dos tomadores de decisão (gestores) aos seus e representam a soma dos: a) custos de criação e estruturação de contratos entre o principal e o agente; b) gastos de monitoramento das atividades dos gestores pelo principal; c) gastos promovidos pelo próprio agente para mostrar ao principal que seus atos não lhe serão prejudiciais; d) perdas residuais, decorrentes da diminuição da riqueza do principal por divergências entre as decisões do agente e as decisões que iriam maximizar a riqueza do principal (JENSEN; MECKLING, 1976). Para Friedman (1970), o engajamento dos gestores em atividades de responsabilidade social pode violar suas atribuições de defesa dos interesses dos acionistas, pois implica em um desvio de recursos da organização que seriam mais bem empregados em projetos internos que agregassem valor ou retornassem aos acionistas.

\subsubsection{RSC nos anos 1960}

Na década de 1960, iniciaram-se tentativas de formalizar o significado de RSC. Um dos primeiros e mais proeminentes escritores nesse período foi Keith Davis, que argumentou que RSC se refere a "decisões e ações dos homens de negócios baseadas, pelo menos em parte, além dos interesses diretamente econômicos e técnicos da empresa” (DAVIS, 1960, p.70). Para esse autor, a responsabilidade social é uma ideia nebulosa, porém deve ser enxergada no 
contexto empresarial. Além disso, argumentou que algumas decisões socialmente responsáveis podem, no longo prazo e mediante um processo complexo, trazer ganhos econômicos para a empresa e, assim, recompensá-la por sua visão socialmente responsável.

Outro autor influente na contribuição da definição inicial de RSC foi William C. Frederick, que afirmou que a responsabilidade social implica em uma postura pública em relação aos recursos econômicos e humanos da sociedade, e uma disposição em ver esses recursos utilizados para fins sociais mais amplos e não somente para interesses de poucos. (FREDERICK, 1960)

No contexto empresarial, o período entre a década de 1950 e a década de 1980 foi caracterizado pelo crescimento e expansão de contribuições. As ações de responsabilidade social concentravam-se na preocupação com a filantropia e obras de caridade centrada no dirigente da organização. Esse comportamento era baseado, sobretudo, na obrigação moral e princípios religiosos compatíveis com os valores da sociedade daquela época. (CARROLL, 1999)

\subsubsection{RSC nos anos 1970}

Eilbert e Parket (1973) realizaram uma pesquisa que revelou quais eram as atividades de RSC adotadas pelas maiores empresas daquela época. O Quadro 1 mostra a lista dessas atividades e o percentual de empresas engajadas em cada uma delas. A lista traz uma ideia do que era considerada a RSC naquele tempo. Outros aspectos, além dos apresentados no quadro, que apareceram na pesquisa foram: relatórios contábeis claros, propagandas não enganosas, produtos sem defeitos, atendimento a reclamações de consumidores e garantias. 
Quadro 1 - Atividades de RSC adotadas pelas maiores empresas na década de 1970.

\begin{tabular}{|c|c|}
\hline Atividade de RSC & Porcentagem de empresas engajadas \\
\hline Contratação de minorias & 100 \\
\hline Preocupação com o meio ambiente & 95 \\
\hline Treinamento de minorias & 91 \\
\hline Contribuiç̃̃es com educação & 91 \\
\hline Contribuição com artes & 83 \\
\hline Revitalização urbana & 62 \\
\hline Direitos civis & 58 \\
\hline
\end{tabular}

FONTE: EILBERT; PARKET, 1973, p. 11.

Na década de 1970, novas direções surgiram em um contexto de protesto contra o capitalismo e crescimento de preocupações sociais, o que levou a uma maior regulamentação governamental e maiores exigências formais (GARRIDA; MELÉ, 2004). Havia mais discussões, principalmente entre acadêmicos, do que ações por parte das empresas, porém, iniciativas legislativas começaram a obrigar os gestores a criar mecanismos organizacionais para cumprir leis sobre meio ambiente, segurança dos produtos, discriminação de funcionários e segurança no trabalho (CARROLL, 2008).

Na parte conceitual, Carroll $(1979,1991)$ propôs um modelo em forma de pirâmide que abrange quatro categorias para RSC: econômica, legal, ética e filantrópica, mostrado na Ilustração 1. A dimensão econômica é a base para todas as outras e reflete a necessidade da empresa manter sua saúde financeira, garantindo sua sobrevivência e crescimento. Esta seria, em tese, a primeira e mais importante responsabilidade social da atividade de negócios, visto que sem ela a empresa não tem como realizar as demais responsabilidades. O segundo nível, a responsabilidade legal, corresponde à adequação das ações da empresa à legislação vigente. $\mathrm{O}$ terceiro nível, a responsabilidade ética, refere-se a um comportamento apropriado, de acordo com as expectativas existentes entre os agentes da sociedade. Por último, o quarto nível, a responsabilidade filantrópica, abriga as iniciativas da empresa em se envolver em soluções para problemas sociais de maneira voluntária. Nesta categoria, o envolvimento não é exigido e nem esperado, porém desejado pela sociedade. 


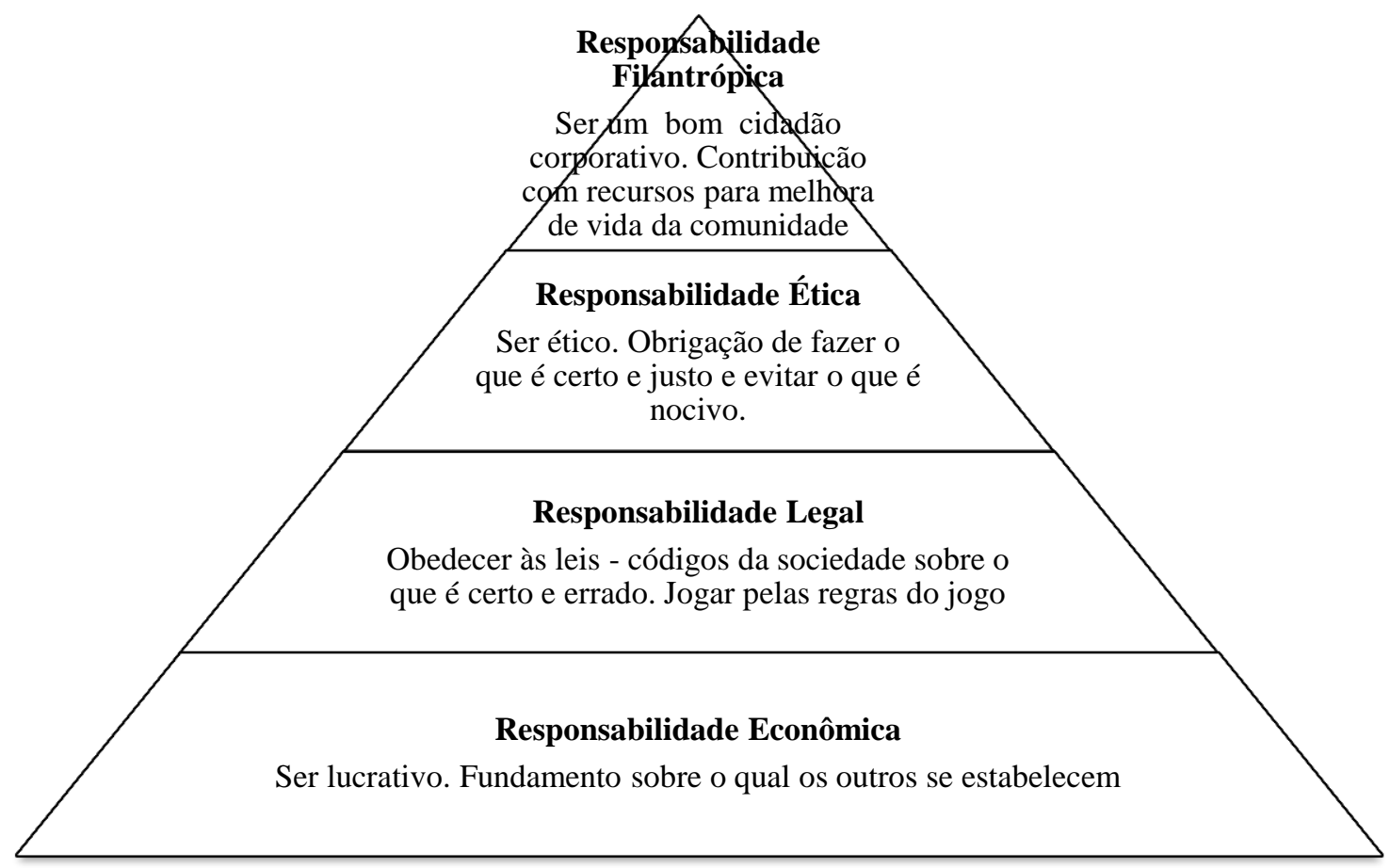

Ilustração 1 - Pirâmide da responsabilidade social. FONTE: CARROLL, 1991, p.42.

Carroll (1979) argumenta que, para os gestores se engajarem na RSC, devem ter: a) uma definição básica do conceito e dos tipos de RSC; b) um entendimento/enumeração das questões existentes sobre RSC; 3) uma especificação da filosofia (ou estratégia) para responder a essas questões.

\subsubsection{RSC nos anos 1980}

Jones (1980) afirma que RSC engloba a noção de que as empresas têm obrigações com outros grupos da sociedade, além dos acionistas, e vão além daquelas prescritas pela lei e por contratos. Nessa definição, a responsabilidade social só existe se for adotada voluntariamente pela empresa e se estende a grupos como consumidores, funcionários, fornecedores e comunidades locais. Uma das maiores contribuições de Jones (1980) foi a ênfase que ele atribuiu a RSC como um processo, argumentando que é muito difícil atingir um consenso sobre o que constitui o comportamento socialmente responsável e, por isso, a RSC não deve ser vista como um conjunto de resultados, mas, sim como um processo. 
Na década de 1980, muitos escândalos éticos empresariais foram divulgados e atraíram a atenção do público para práticas possivelmente prejudiciais das empresas. Alguns exemplos foram: a explosão da Union Carbide Bhopal, na Índia, que matou milhares de pessoas; a controvérsia sobre empresas que faziam negócios na África do Sul e eram acusadas de apoiar o Apartheid; o escândalo sobre informações privilegiadas envolvendo o corretor de ações, Ivan Boesky. As discussões sobre as práticas das empresas estavam relacionadas, principalmente, à poluição do meio ambiente, discriminação de funcionários, saúde e segurança dos funcionários, qualidade de vida no trabalho, deterioração da vida urbana e questionamento das atividades de companhias multinacionais. (CARROLL, 2008)

\subsubsection{RSC nos anos 1990}

$\mathrm{Na}$ década de 1990, os trabalhos acadêmicos começaram a investigar a relação entre Desempenho Social e Desempenho Financeiro. Na arena dos negócios, a filantropia se expandiu, consideravelmente, e as atividades de RSC passaram a se caracterizar por diversificação e globalização. Os beneficiários das ações incluíam educação, cultura e arte, serviços de saúde, organizações não governamentais (ONGs) e doações internacionais. Além disso, algumas empresas começaram a desenvolver reputação por boas práticas sociais, como Coca-Cola, IBM, Johnson \& Johnson e McDonald's, apesar de já haver certo ceticismo sobre a sinceridade e a natureza de suas práticas (CARROLL, 2008).

Jones (1996) faz uma abordagem crítica à RSC, concluindo que o conceito e o discurso da RSC carecem de coerência teórica, validade empírica e viabilidade normativa. O autor considera que os argumentos a favor da RSC se enquadram em duas linhas básicas, as quais podem ser classificadas como linhas ética e instrumental. A linha ética deriva dos princípios religiosos e das normas sociais prevalecentes e considera que as empresas e as pessoas devem se comportar de maneira socialmente responsável, mesmo que envolva despesas improdutivas para a empresa, pois essa é a ação moralmente correta. Já a linha instrumental considera que há uma relação positiva entre comportamento socialmente responsável e desempenho financeiro da empresa, pois, a ação proativa em relação à RSC traz oportunidades geradas pela antecipação de regulações restritivas do governo à ação empresarial e pela diferenciação de produtos diante de competidores menos responsáveis socialmente. 
Michalos (1997) afirma que as empresas são responsáveis pelas implicações de suas atividades na sociedade e devem prestar contas de seus impactos diretos, assim como de impactos indiretos, considerando toda a cadeia produtiva e todo o ciclo de vida de seus produtos. Para esse autor, a RSC engloba parcerias entre clientes e fornecedores, qualidade dos produtos, satisfação de clientes, contribuições para o desenvolvimento de comunidades, investimentos em pesquisas, preservação ambiental, participação dos trabalhadores nos resultados e nas decisões da empresa, diversidade, segurança no trabalho e desenvolvimento profissional.

Diante de tantos conceitos e diversas premissas sobre o que deve abranger a responsabilidade social da empresa, o Triple Bottom Line (TBL), emergiu como uma forma de interpretação da RSC comumente adotada pelas empresas. O modelo foi criado por Elkington (1997), que argumentou que as organizações podem exercer o desenvolvimento sustentável se avaliarem os aspectos econômicos, sociais e ambientais de suas atividades. $\mathrm{O}$ autor defende que a empresa deve atribuir pesos equivalentes para cada uma destas três dimensões.

O modelo do TBL está baseado no conceito de desenvolvimento sustentável, que ganhou notoriedade após a publicação do relatório Brundtland, realizado pela WCED, da ONU, em 1987. O relatório destaca que, para atingir o desenvolvimento sustentável, as empresas devem atender às necessidades da geração atual sem comprometer a possibilidade das gerações futuras suprirem suas próprias necessidades.

A ideia base do TBL é que o sucesso e saúde da empresa não devem ser avaliados somente por medidas financeiras tradicionais, mas também por sua responsabilidade social e seu desempenho ambiental (NORMAN; MACDONALD, 2004). Apesar de cada uma dessas dimensões representar um grande desafio para os gestores, o segmento corporativo vem atendendo às demandas cada vez maiores da sociedade frente a essas questões, e seu papel na economia, sociedade e meio ambiente vem sendo cada vez mais discutido (SILVA; QUELHAS, 2006). 


\subsection{6}

RSC nos anos 2000

Nos anos 2000, novas pesquisas empíricas foram realizadas tentando relacionar Desempenho Social com Desempenho Financeiro e com outras variáveis relevantes. Zyglidopolous (2001) estudou o impacto de acidentes na reputação da empresa no Desempenho Social. O autor descobriu que acidentes e suas complicações possuem um papel importante na percepção de reputação. Backhaus et al. (2002) exploraram a relação entre Desempenho Social e atratividade de funcionários. Os pesquisadores chegaram à conclusão de que pessoas que procuram emprego consideram fatores como meio ambiente, relação com a comunidade e trabalhadores, diversidade e questões relativas a produtos para escolherem as empresas nas quais trabalhar.

Na parte conceitual, Schwartz e Carroll (2003) sugeriram um novo modelo de RSC, mostrado na Ilustração 2, com base no modelo anterior de Carroll (1979, 1991). A dimensão filantrópica foi retirada do antigo modelo e incluída na dimensão ética, reduzindo-o a três dimensões. O novo modelo foi chamado de "Three Domain Approach" e é representado por um diagrama de Venn. Neste modelo, nenhuma das três dimensões centrais (econômica, legal, ou ética) é considerada mais importante ou significante comparada às outras.

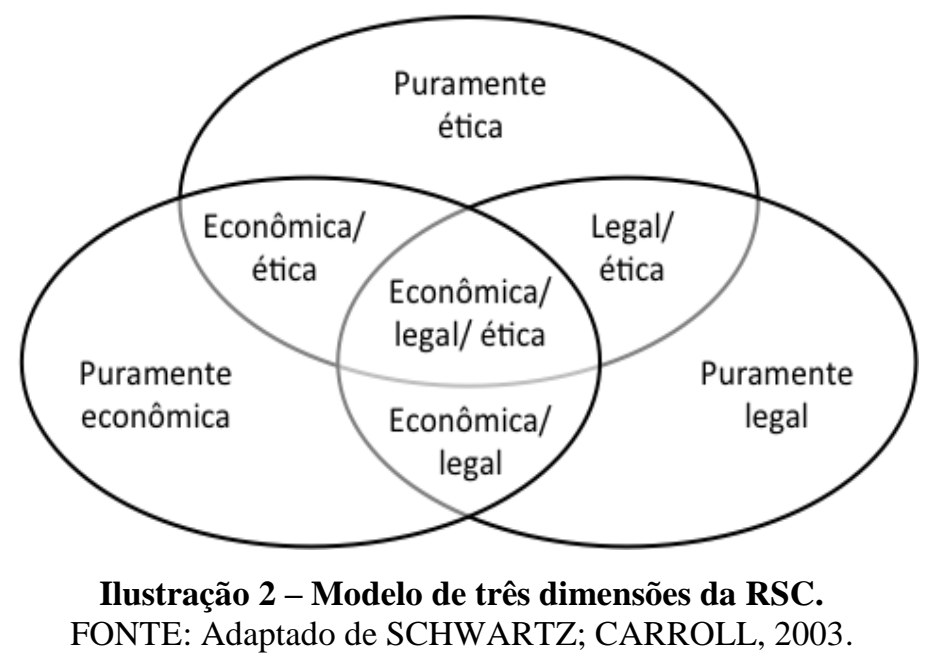

Por meio da intersecção das categorias, pode-se identificar o surgimento de outras dimensões, fazendo que a estrutura se amplie para sete categorias, intituladas: puramente econômica, puramente legal, puramente ética, econômico-ética, econômico-legal, legal-ética e econômico-legal-ética, que resultam da sobreposição das três dimensões principais. Os autores ressaltam que as ações socialmente responsáveis praticadas pelas empresas raramente 
são classificadas em apenas uma das dimensões, uma vez que existe um entrelaçamento das dimensões puramente econômica, legal e ética. Alterando o tamanho e a dominância de cada elemento do modelo, pode-se visualizar diferentes retratos de RSC que podem servir para comparar as companhias. (SCHWARTZ; CARROLL, 2003)

Conciliar esses três níveis pode se tornar um desafio para os gestores, pois, muitas vezes, parte-se do pressuposto de que atender exigências legais e éticas sacrifica resultados econômicos. Entretanto, é justamente nesta interface que parece residir um potencial competitivo para as organizações. Empresas que transitam com consistência pelos três níveis de responsabilidade podem se beneficiar economicamente de ações éticas, uma vez que esses níveis não são estanques e ações em um nível acarretam consequências nos demais. (BUCHHOLTZ; CARROLL, 2009)

Na medida em que uma sociedade reforça sua base civil, composta pelo conjunto de normas, costumes e leis, práticas como respeito a direitos do consumidor e preservação do meio ambiente passam a ser obrigações legais. A base civil de uma sociedade e, consequentemente, a demanda pela RSC tendem a crescer conforme aumenta o desenvolvimento econômico do país. (MARTIN, 2002)

Neste contexto, as organizações estão sendo desafiadas a participar cada vez mais desta discussão e a adotar atividades socialmente responsáveis. Da mesma forma, as organizações brasileiras estão inseridas neste novo cenário e vêm implementando ações no sentido de incorporar os conceitos de RSC.

\subsection{RSC no Contexto Brasileiro}

No Brasil, entidades do terceiro setor, como Pensamento Nacional das Bases Empresariais (PNBE), Grupo de Institutos, Fundações e Empresas (GIFE), Instituto Ethos e Instituto Brasileiro de Análises Sociais e Econômicas (IBASE), têm tido um importante papel para a evolução do entendimento e da prática da RSC. Algumas delas, como o GIFE e o Instituto Ethos são inspiradas na organização americana Business for Social Responsibility. 
O PNBE é uma entidade não governamental brasileira formada por empresários de diversos ramos da atividade econômica, de todas as regiões do país e de todos os portes de empresas, cuja missão é "articular empresários e associações para tornar o país economicamente mais desenvolvido, socialmente mais justo e politicamente mais democrático”. O PNBE foi criado em 1987 e foi a primeira entidade no país a associar empresários para desenvolver atividades voltadas à RSC. (PNBE, 2012)

O GIFE busca orientar empresas e fundações na realização de projetos sociais por meio do Investimento Social Privado, que é considerado como "o repasse voluntário de recursos privados de forma planejada, monitorada e sistemática para projetos sociais, ambientais e culturais de interesse público". Incluem-se neste universo as ações sociais protagonizadas por empresas, fundações e institutos de origem empresarial ou familiar, comunidades ou indivíduos. De acordo com a organização, os elementos fundamentais que diferenciam essa prática das ações assistencialistas são: preocupação com planejamento, monitoramento e avaliação dos projetos; estratégia voltada para resultados sustentáveis de impacto e transformação social; envolvimento da comunidade no desenvolvimento da ação. (GIFE, 2012)

O Instituto Ethos é uma organização não governamental criada em 1998 e se propõe a disseminar a prática da RSC por meio, principalmente, do estabelecimento de parâmetros para as empresas interessadas no assunto. $\mathrm{O}$ instituto criou os Indicadores Ethos de Responsabilidade Social, por meio dos quais as empresas podem avaliar sua gestão na perspectiva de sete temas: valores, transparência e governança; público interno; meio ambiente; fornecedores; consumidores e clientes; comunidade; governo e sociedade. (INSTITUTO ETHOS, 2012)

De acordo com o Instituto Ethos (2012), RSC é:

A forma de gestão que se define pela relação ética e transparente da empresa com todos os públicos com os quais ela se relaciona e pelo estabelecimento de metas empresariais que impulsionem o desenvolvimento sustentável da sociedade, preservando recursos ambientais e culturais para as gerações futuras, respeitando a diversidade e promovendo a redução das desigualdades sociais. 
Uma das formas de divulgar as ações das organizações brasileiras com relação à RSC é a publicação do Balanço Social. O IBASE é o responsável pela criação do Balanço Social, o qual é definido por:

\footnotetext{
Um demonstrativo publicado anualmente pela empresa reunindo um conjunto de informações sobre os projetos, benefícios e ações sociais dirigidas aos empregados, investidores, analistas de mercado, acionistas e à comunidade. (IBASE, 2012)
}

O Balanço Social começou a ser discutido no Brasil na década de 70. Porém, apenas nos anos 80, surgiram os primeiros balanços sociais de empresas e, a partir da década de 90, corporações de diferentes setores passaram a publicar o balanço social, anualmente. A proposta ganhou visibilidade nacional, quando o sociólogo Herbert de Souza, o Betinho, lançou, em junho de 1997, uma campanha pela divulgação voluntária do balanço social. (IBASE, 2012)

A ideia do balanço é que as informações sejam apresentadas conforme um padrão mínimo, para a avaliação da função social da empresa. Apesar da dificuldade em se correlacionar fatores financeiros com fatos sociais, a predominância de dados que possam ser expressos em valores financeiros ou de forma quantitativa é útil para ajudar as análises comparativas da própria empresa ao longo do tempo ou entre outras do mesmo setor (IBASE, 2012). O desenvolvimento do balanço social por parte das organizações demonstra a mudança da visão tradicional para uma visão mais moderna, com a incorporação da responsabilidade social juntamente com os lucros (NASCIMENTO et al., 2008).

Em 1998, para estimular a participação de um maior número de corporações, o IBASE lançou o Selo Balanço Social IBASE/Betinho. O selo é conferido anualmente a todas as empresas que publicam o Balanço Social no modelo sugerido pelo instituto, dentro da metodologia e dos critérios propostos. Com esse selo as empresas podem mostrar em seus anúncios, embalagens, sites e campanhas publicitárias que investem em educação, saúde, cultura, esportes e meio ambiente. (IBASE, 2012)

A criação de entidades com objetivos de disseminar e incentivar práticas de RSC já demonstra que o assunto está inserido nas preocupações empresariais. Somente para confirmar tal contexto, as empresas associadas ao Instituto Ethos representam 1/3 do PIB Brasileiro. (GOMES; MORETTI, 2007) 
Vale ressaltar que as organizações, apesar de neutras, pois não asseguram que tais ou quais empresas sejam de fato socialmente responsáveis, visam a "instituir", isto é, regulamentar, regrar, estabelecer uma conduta. Portanto, mais uma vez a ideia de criar modelos para, a partir deles, ditar o "certo" e o "errado" parece ser uma tônica quando se dialoga com a RSC. (GOMES; MORETTI, 2007)

A Pesquisa sobre Ação Social das Empresas Brasileiras, realizada pelo Instituto de Pesquisas Econômicas Aplicadas (IPEA), indica que houve um crescimento, entre 2000 e 2004, na proporção de empresas privadas que realizaram ações sociais em benefício das comunidades. Neste período, a participação empresarial, na área social, aumentou de 59\% para 69\%, o que corresponde a 600 mil empresas. (IPEA, 2006)

Ainda de acordo com essa pesquisa, o montante do investimento em ações sociais é pouco influenciado pela política de benefícios tributários, uma vez que apenas $2 \%$ das empresas que atuaram no social fizeram uso de incentivos fiscais. Dentre os motivos da não utilização desses benefícios, cerca de $40 \%$ dos empresários alegaram que o valor do incentivo era muito pequeno e que, portanto, não compensava seu uso. Para 16\%, as isenções permitidas não se aplicavam às atividades desenvolvidas e outros $15 \%$ não sabiam da existência de tais benefícios. (IPEA, 2006)

Com relação ao que dificulta ou impede o desenvolvimento de ações sociais comunitárias, $62 \%$ das empresas apontam como principal motivo a falta de dinheiro. Uma parcela bem menor destacou a ausência de incentivos governamentais (11\%). Também é pequena a proporção de empresas que não atua porque nunca pensou nessa possibilidade (5\%) ou porque acredita que este não seja seu papel (5\%). (IPEA, 2006)

A pesquisa também procurou investigar a percepção dos empresários sobre o seu papel na realização de ações voluntárias em benefício das comunidades. A grande maioria (78\%) acredita que é obrigação do Estado cuidar do social e que a necessidade de atuar para as comunidades é maior hoje do que há alguns anos (65\%). O Gráfico 1 traz informações sobre a percepção dos empresários sobre sua atuação na área social e o Gráfico 2 sobre os motivos que levam as empresas a realizar ações sociais, de acordo com a pesquisa do IPEA (2006). 
É obrigação do Estado cuidar do social; as empresas atuam porque os governos não cumprem seu papel

Para as empresas, a necessidade de realizar atividades sociais para comunidades é maior agora do que há alguns anos

O Estado sozinho não é capaz de resolver os problemas sociais; portanto, as empresas têm que dar sua contribuição

É papel das empresas realizar atividades sociais para comunidades carentes

As empresas devem realizar atividades sociais para fortalecer ou ampliar o alcance de políticas públicas e programas governamentais

Para as empresas contribuírem para a comunidade basta pagar impostos, gerar empregos e garantir qualidade de seus produtos ou serviços

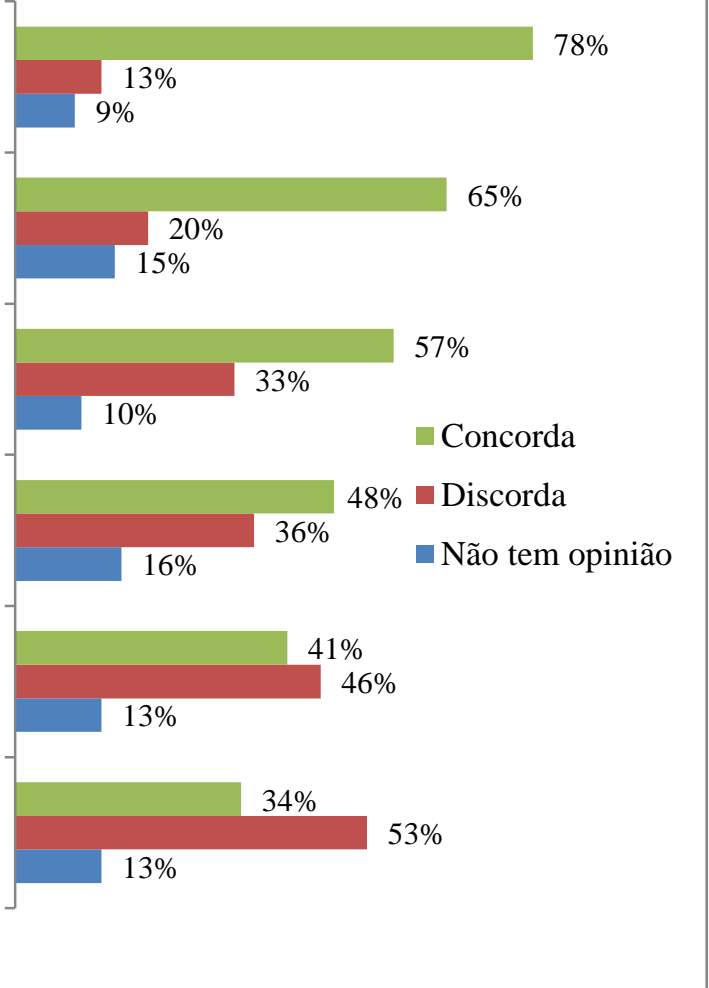

Gráfico 1 - Percepção dos empresários sobre sua atuação na área social. FONTE: IPEA, 2006.

Atender a motivos humanitários

Atender a pedidos de outras entidades (governamentais ou comunitárias) Atender a comunidades próximas ao local da empresa

Atender a apelos de campanhas públicas (enchentes, secas, fome, etc.)

Atender motivos religiosos

Aumentar a satisfação dos empregados da empresa

Melhorar a imagem da empresa

Atender solicitação de amigos/políticos

Complementar a ação do governo

Aumentar a produtividade e melhorar a qualidade do trabalho

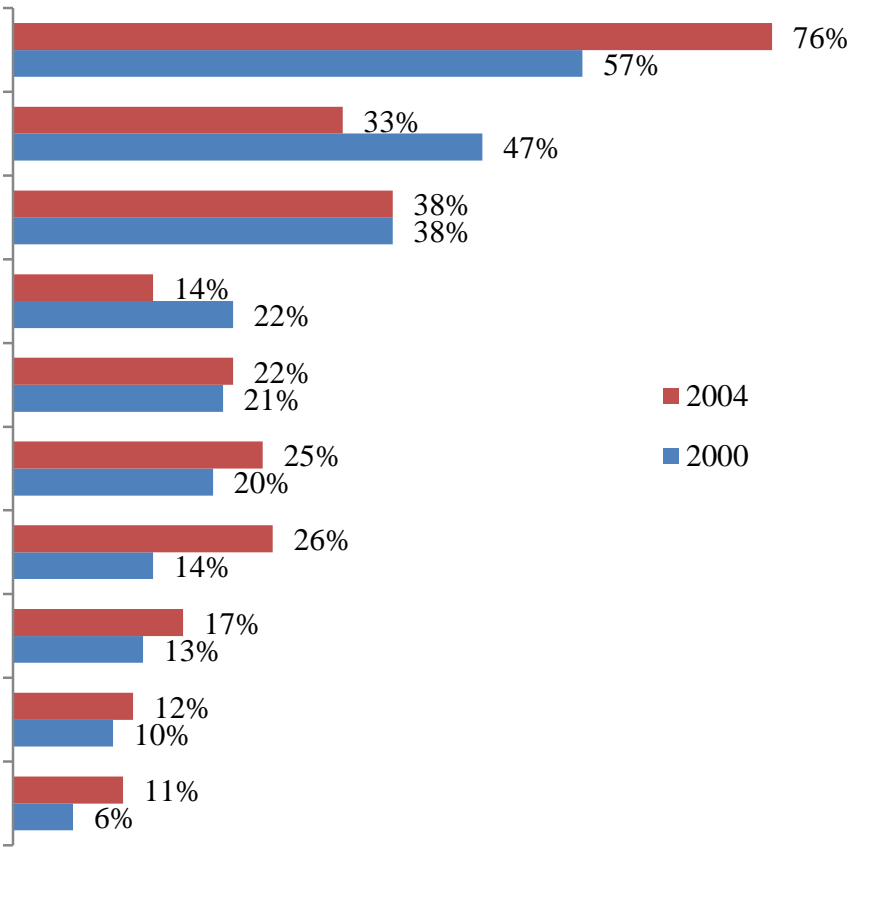

Gráfico 2 - Motivos pelos quais as empresas realizam ações sociais, em 2000 e 2004. FONTE: IPEA, 2006. 
Nota-se que, na pesquisa, a ação social das empresas é tratada apenas como ações voltadas para as comunidades, ou seja, tem caráter puramente filantrópico, o que está muito distante da visão da RSC como meio de geração de valor compartilhado, tanto para a empresa como para a sociedade. As abordagens de RSC feitas pelas entidades do terceiro setor também parecem estar voltadas, principalmente, para a realização de projetos sociais e para o estabelecimento de condutas consideradas "éticas", o que torna a RSC muito distante do objetivo e das atividades principais das empresas.

\subsection{Principais Teorias de RSC}

$\mathrm{Na}$ literatura, podem-se distinguir quatro grupos principais de teorias de RSC, considerando seus respectivos focos em quatro diferentes aspectos da realidade social: 1) Teoria do Desempenho Social Corporativo, baseada na Sociologia; 2) Teoria do Valor ao Acionista, que surgiu de uma teoria particular da Economia chamada por alguns autores de Fundamentalismo; 3) Teoria dos Stakeholders, baseada em perspectivas éticas; 4) Cidadania Corporativa, cujas raízes estão em Estudos Políticos. O primeiro grupo destaca o poder social da corporação e sua responsabilidade na arena politica associada ao seu poder. Para o segundo grupo a corporação é vista como um mero instrumento para criação de riqueza. O terceiro grupo foca em ética, incluindo teorias que consideram que a relação entre empresas e sociedade deve ser permeada por valores éticos. Finalmente, o quarto grupo foca na integração social, incluindo teorias que consideram que os negócios deveriam integrar demandas sociais. (GARRIDA; MELÉ, 2004)

\subsubsection{Teoria do Desempenho Social Corporativo}

Desempenho Social Corporativo (DSC) ou Corporate Social Performance (CSP) é conceituado como o amplo conjunto de estratégias e práticas operacionais que a empresa desenvolve para lidar e criar relacionamentos com os seus inúmeros stakeholders e com o meio ambiente (WADDOCK, 2004). A Teoria do DSC é entendida como a configuração, na organização empresarial, de princípios de responsabilidade social, processos de respostas a exigências sociais e políticas, programas e resultados tangíveis, que refletem a relação da empresa com a sociedade (WOOD, 1991). Essa teoria sustenta que as empresas, além das 
responsabilidades econômicas e legais, também possuem responsabilidades com os problemas sociais causados pelos negócios ou por outros motivos. Isso inclui exigências éticas e ações discricionárias ou filantrópicas realizadas pelas empresas em favor da sociedade. Em outras palavras, melhorar o Desempenho Social significa alterar o comportamento organizacional para produzir menos danos e resultados mais benéficos para a sociedade (WOOD, 1991)

A fim de determinar responsabilidades específicas, autores dessa teoria dão ênfase à importância de prestar atenção às expectativas da sociedade em relação à empresa e às necessidades sociais. Entre outros argumentos do DSC, é enfatizado que os negócios possuem poder, e poder requer responsabilidade. É enfatizado também que a empresa ficaria vulnerável caso seu desempenho fosse contrário às expectativas das pessoas que constituem o ambiente social da empresa (DAVIS, 1975). A reputação da empresa é relacionada também à aceitação da comunidade na qual ela opera. Não obstante, as consequências econômicas em longo prazo para a empresa, as quais nem sempre são fáceis de medir, não são a principal consideração para muitos autores, que apontam que assumir responsabilidades sociais não é considerada, primeiramente, uma questão econômica, mas uma questão social e ética: ser responsável é fazer a coisa certa. (GARRIDA; MELÉ, 2004)

O modelo do DSC é uma síntese relevante do desenvolvimento da RSC até a década de 1980, porém, sua principal limitação pode ser considerada a falta de integração entre aspectos normativos éticos e a atividade das empresas. Essa teoria parece apenas dar uma face mais humana ao capitalismo, porém separa completamente ética e economia. (GARRIDA; MELÉ, 2004)

\subsubsection{Teoria do Valor ao Acionista}

A teoria do Valor ao Acionista afirma que a única responsabilidade social dos negócios é gerar lucros e seu principal objetivo é aumentar o valor econômico da empresa para seus acionistas. A empresa somente poderia se engajar em outras atividades sociais, caso fossem exigidas por lei ou se contribuíssem para maximização do valor ao acionista. Essa teoria está fundamentada na Teoria Econômica Neoclássica, a qual está primeiramente preocupada com maximização da utilidade do acionista. O principal representante dessa visão é Milton Friedman que, em seu famoso artigo publicado na New York Times Magazine em 1970, 
afirmou que a única responsabilidade da empresa perante a sociedade é a maximização dos lucros aos acionistas, dentro do quadro legal e dos costumes éticos do país. (FRIEDMAN, 1970)

$\mathrm{O}$ argumento principal dos que defendem essa corrente é enfatizar a eficiência desse modelo para criar valor. Para eles, administrar uma empresa pela maximização do valor ao acionista não consiste somente em aumentar a riqueza dos acionistas, mas também atingir um melhor desempenho econômico de todo o sistema. Essas condições promovem o incentivo à inovação, redução de custos e preços, produtos com valor econômico agregado e capital para futuros investimentos. Além disso, argumentam que o sistema de impostos permite que parte da riqueza gerada seja dividida com a sociedade por intermédio do governo, que, com ações e leis apropriadas, poderia resolver os problemas de desigualdades e outros problemas gerados pelo mercado. (LAZONICK; O’SULLIVAN, 2000)

Na prática, a maximização do valor ao acionista frequentemente reflete lucros de curto prazo, como redução em despesas com pessoal. Há evidências que o sucesso econômico em longo prazo não pode ser atingido a menos que os gestores considerem não apenas os interesses dos acionistas, mas também os interesses dos funcionários, clientes, fornecedores, comunidades locais e outros grupos ligados às atividades da empresa - os chamados stakeholders (CLARKSON, 1995). Dessa forma, as principais críticas a essa teoria se referem à estreita visão que é dada aos seres humanos, limitada a liberdade de escolha e interesse próprio, à visão atomizada da sociedade e à concepção das atividades da empresa como independentes da sociedade. (GARRIDA; MELÉ, 2004)

\subsubsection{Teoria dos Stakeholders}

Ao contrário da Teoria dos Acionistas, a Teoria dos Stakeholders leva em consideração os indivíduos ou grupos que possuem ligação com a empresa. A definição de stakeholder mais conhecida e utilizada foi criada por Freeman (1984, p. 46), que afirma que stakeholder significa "qualquer grupo ou indivíduo que pode afetar ou é afetado pelo alcance dos objetivos da empresa". Nessa visão a empresa é gerida com a finalidade de gerar benefícios para seus clientes, fornecedores, proprietários, funcionários e comunidades locais, além de manter a sobrevivência da empresa (JONES, 1980). Pode ser classificada como uma teoria de 
RSC, uma vez que fornece um framework normativo para responsabilidade da empresa perante a sociedade.

Essa teoria pode ser considerada eticamente superior à teoria do valor ao acionista por apontar os diretos e interesses legítimos dos stakeholders, e não apenas o que é requerido por lei. Além disso, contribui para um conceito menos vago de RSC, ao abordar interesses e práticas concretas e ao visualizar responsabilidades a grupos específicos afetados pelas atividades das empresas (CLARKSON, 1995). Outro ponto forte dessa abordagem é que não é somente uma teoria ética, desconectada da administração dos negócios, mas também relacionada ao sucesso dos negócios.

Alguns críticos dessa teoria afirmam que ela não fornece funções específicas e objetivas para as empresas, uma vez que balancear os interesses dos stakeholders abandona uma base objetiva para avaliar as ações dos negócios. Além disso, a teoria permite várias interpretações e cada interpretação nos fornece um diferente grupo de stakeholders e salienta a importância de diferentes valores, direitos e interesses. Assim, interpretações de diferentes stakeholders levariam a diferentes distribuições de benefícios e deveres. (GARRIDA; MELÉ, 2004)

\subsubsection{Teoria da Cidadania Corporativa}

O termo cidadania vem da Ciência Política e contém a ideia geral de fazer parte de uma comunidade. Dessa forma, a teoria da cidadania corporativa considera que a empresa seja parte da sociedade e, por essa razão, deve contribuir com o bem comum, principalmente, na comunidade onde atua, como "boa cidadã". O conceito central de cidadania é participação ao invés de direitos individuais. Essa teoria está mais focada em deveres, responsabilidades e possíveis parcerias das empresas com grupos da sociedade e instituições. (MATTEN; CRANE, 2005)

Na década de 1990, o conceito de cidadania corporativa ganhou força e atraiu a atenção de empresas devido, principalmente, ao processo de globalização e ao grande poder das empresas multinacionais, uma vez que o conceito de cidadania corporativa possui um apelo global. Porém, não existe ainda uma teoria completa sobre Cidadania Corporativa, apesar dos 
trabalhos de alguns pesquisadores (WOOD; LOGSDON, 2002; MATTEN; CRANE, 2005) que tentam desenvolver conceitos e teorias normativas.

As principais críticas a essa teoria se referem principalmente ao conceito em si, que é muito difuso e pode incluir diversos tópicos, como parceria público-privada, práticas corporativas éticas, contribuições corporativas, voluntariado corporativo e gestão corporativa de marca, imagem e reputação. Outra crítica a essa abordagem é que não agrega nada novo para o entendimento da relação entre empresa e a sociedade. (GARRIDA; MELÉ, 2004)

O Quadro 2 traz um resumo das principais teorias mapeadas de RSC, destacando suas origens, principais ideias e principais autores.

Quadro 2 - Principais teorias de RSC.

\begin{tabular}{|c|c|c|c|}
\hline Teoria de RSC & Origem & Ideia Principal & Principais Autores \\
\hline $\begin{array}{c}\text { Desempenho Social } \\
\text { Corporativo }\end{array}$ & Sociologia & $\begin{array}{c}\text { "Assumir responsabilidades } \\
\text { sociais não é uma questão } \\
\text { primeiramente econômica, mas } \\
\text { sim uma questão social e } \\
\text { ética". }\end{array}$ & $\begin{array}{c}\text { Davis (1975); Wood } \\
(1991) .\end{array}$ \\
\hline Teoria do Valor ao Acionista & Economia & $\begin{array}{c}\text { "A única responsabilidade dos } \\
\text { negócios é gerar lucros aos } \\
\text { seus acionistas". }\end{array}$ & $\begin{array}{c}\text { Friedman (1970), } \\
\text { Lazonick e O'Sullivan } \\
\text { (2000). }\end{array}$ \\
\hline Teoria dos Stakeholders & Ética & $\begin{array}{c}\text { "A empresa é gerida com a } \\
\text { finalidade de gerar benefícios } \\
\text { para seus clientes, } \\
\text { fornecedores, proprietários, } \\
\text { funcionários e comunidades } \\
\text { locais, além de manter sua } \\
\text { sobrevivência". }\end{array}$ & $\begin{array}{c}\text { Jones (1980); Freeman } \\
\text { (1984); Clarkson } \\
\text { (1995). }\end{array}$ \\
\hline Cidadania Corporativa & Ciências Políticas & $\begin{array}{c}\text { "A empresa, como parte da } \\
\text { sociedade, deve agir como boa } \\
\text { cidadã". }\end{array}$ & $\begin{array}{c}\text { Wood e Logsdon, } \\
\text { (2002); Matten e Crane } \\
\text { (2005). }\end{array}$ \\
\hline
\end{tabular}

FONTE: Baseado em GARRIDA; MELÉ, 2004.

A classificação apresentada é útil para a contextualização dos diversos estudos existentes sobre RSC, os quais utilizam diversos conceitos e fontes para tratar da mesma questão. Essa classificação considera o foco principal de cada uma delas, porém, na maioria dos casos, abordam mais de um aspecto e há muitas conexões entre elas. O presente trabalho busca fundamentação na Teoria do DSC, a qual está profundamente ligada à Teoria dos Stakeholders na literatura. Além disso, busca-se conciliar essas duas teorias com a Teoria do Valor ao Acionista, evidenciando que o Desempenho Social pode gerar Desempenho Financeiro. 


\subsection{Desempenho Social Corporativo}

\subsubsection{Modelos de DSC}

O DSC é uma função do ajuste entre a natureza da questão social e sua estratégia e estrutura correspondente. Esse ajuste leva a uma integração de elementos como responsividade social corporativa, gestão de questões sociais e gestão de stakeholders (HUSTED, 2000). O DSC reflete a ideia de que as responsabilidades são parte integrante das ações, decisões, comportamentos e impactos corporativos (SURROCA et al., 2010).

Wood (1991) criou um modelo de DSC, cujas dimensões abrangem: princípios de responsabilidade social corporativa; processos de responsividade social; resultados de desempenho social corporativo. A dimensão de "princípios de responsabilidade social corporativa" está subdividida em três níveis: a) nível institucional, que se refere à legitimidade; b) nível organizacional, que se preocupa com a responsabilidade pública; c) nível individual, que abrange o arbítrio dos executivos. Nos "processos de responsividade social" estão incluídas a percepção sobre o meio ambiente, a gestão de stakeholders e a administração de questões sociais. Finalmente, a dimensão "resultados de desempenho social corporativo" estuda os impactos sociais; programas sociais envolvendo o meio ambiente; comunidade e fornecedores; políticas sociais e os efeitos institucionais externos.

Clarkson (1995) propõe um modelo para avaliação do desempenho da empresa fundamentado na gestão de seus relacionamentos com os diversos grupos de stakeholders. Para o autor, stakeholders são pessoas ou grupos de pessoas que reivindicam ou dispõem de propriedade, direitos ou interesses na empresa e em suas atividades, no passado, presente e futuro. Direitos ou interesses reivindicados são resultado de ações tomadas pela empresa, podendo ser de ordem legal ou moral e individual ou coletiva. Pode-se dividir os stakeholders em dois grandes grupos: externos e internos. Stakeholder externo é qualquer indivíduo ou grupo de indivíduos que tenha um interesse real ou potencial, ou que interfira de alguma forma na capacidade da organização de alcançar seus objetivos, mas que está fora da organização. Podem ser clientes, fornecedores, comunidade na qual a empresa opera, sindicatos, parceiros, terceiros que prestam serviço à organização, mídia e formadores de opinião, poder público municipal, estadual e federal, e outros. Os stakeholders internos são os públicos de interesse 
que estão dentro da organização, como sócios, acionistas, diretores, empregados, voluntários, e outros.

Após a identificação dos principais grupos de interesse da organização, surgem questões como: O que eles esperam da organização? Quais são, de fato, seus verdadeiros interesses? Seus interesses são legítimos? Seus interesses poderão ser atendidos? Caso sim, total ou parcialmente? Esses interesses são compatíveis com o propósito da organização? Existe alguma forma de compensação por algum interesse que não possa ser atendido? O que está sendo feito para atendê-los? O que deveria ser incluído no plano estratégico da instituição para atender aos interesses legítimos e legais dos grupos de interesse? (NASCIMENTO et al., 2008)

O Quadro 3 apresenta as orientações que a empresa pode adotar com focos em cada grupo de stakeholder, e seus respectivos objetivos e tipos de visão predominante. Ressalta-se que essas orientações podem ser combinadas entre si.

Quadro 3 - Orientação da empresa para seus stakeholders.

\begin{tabular}{|c|c|c|}
\hline Orientação & Objetivo & Visão \\
\hline Acionistas & Maximização do Lucro & Econômica \\
\hline Estado/Governo & $\begin{array}{c}\text { Cumprimento das Obrigações } \\
\text { Legais }\end{array}$ & Juríca \\
\hline Empregados & $\begin{array}{c}\text { Reter e Atrair Funcionários } \\
\text { Qualificados }\end{array}$ & Recursos Humanos \\
\hline Comunidade & $\begin{array}{c}\text { Relacionamento Socialmente } \\
\text { Responsável com a Comunidade } \\
\text { na qual de insere }\end{array}$ & Assistencialista \\
\hline Fornecedores e Compradores & Relações Comerciais Éticas & Cadeia de Produção e Consumo \\
\hline Ambiente Natural & Desenvolvimento Sustentável & Ambiental \\
\hline
\end{tabular}

FONTE: ASHLEY, 2003, p. 37

As organizações são sistemas abertos, isto é, realizam trocas em suas fronteiras, tanto internas quanto externas. Sistema é qualquer conjunto de elementos dinamicamente relacionados entre si, formando uma atividade para atingir um objetivo, operando sobre entradas (informação, energia, matéria) e fornecendo saídas (informação, energia e matéria) processadas (NASCIMENTO et al., 2008). A continuidade da empresa depende de sua habilidade em cumprir com seus objetivos econômicos e sociais, gerando valor para que cada grupo de interesses permaneça nesse sistema. $\mathrm{O}$ equilíbrio nas relações com os diferentes grupos é essencial e evita que relações desses grupos com a empresa sejam cortadas (CLARKSON, 1995). 
A fim de avaliar a posição da organização em relação às questões socioambientais, deve-se analisar: a) ramo de atividade da organização; b) produto desenvolvido; c) tipo de processo de industrialização; d) nível de conscientização ambiental; e) cumprimento da legislação ambiental; f) comprometimento da alta direção; g) capacitação de pessoal; h) capacidade de desenvolver pesquisa e desenvolvimento; i) retorno do investimento na questão socioambiental (NASCIMENTO et al., 2008).

Clarkson (1995) propõe um modelo de avaliação do DSC baseado em dois estágios: no primeiro caracterizam-se as posturas e estratégias de relacionamento por parte da organização com seus stakeholders e, no segundo, mensura-se o desempenho organizacional pela satisfação destes stakeholders, ou seja, avalia-se até que ponto as ações organizacionais estão atendendo as reivindicações destes grupos em questão. O Quadro 4 mostra os tipos de postura que as empresas podem adotar e seus respectivos desempenhos esperados.

Quadro 4 - Escala das estratégias de DSC.

\begin{tabular}{|c|c|c|}
\hline Escala & Postura/Estratégia & Desempenho \\
\hline Reativa & Nega responsabilidade & Faz menos que o requerido \\
\hline Defensiva & $\begin{array}{c}\text { Admite, mas luta contra a } \\
\text { responsabilidade }\end{array}$ & Faz o mínimo requerido \\
\hline Acomodada & Aceita a responsabilidade & Faz tudo que é requerido \\
\hline Proativa & Antecipa a responsabilidade & Faz mais do que é requerido \\
\hline
\end{tabular}

FONTE: Adaptado de CLARKSON, 1995, p.109.

No contexto brasileiro, Tachizawa (2002) descreve cinco estágios, apresentados no Quadro 5, em que as organizações podem se enquadrar, de acordo com suas atitudes frente às questões de RSC. 
Quadro 5 - Estágios e atitudes das organizações frente à RSC.

\begin{tabular}{|c|c|}
\hline Estágio & Atitude Organizacional \\
\hline 1 & $\begin{array}{r}\text { A organização não assume responsabilidades perante a sociedade e não toma ações em relação ao } \\
\text { exercício da cidadania. Não há promoção do comportamento ético. }\end{array}$ \\
\hline 2 & $\begin{array}{c}\text { A organização reconhece os impactos causados por suas atividades, apresentando algumas ações } \\
\text { isoladas no sentido de minimizá-las. Eventualmente busca promover o comportamento ético. }\end{array}$ \\
\hline 3 & $\begin{array}{c}\text { A organização está iniciando a sistematização de um processo de avaliação dos impactos de suas } \\
\text { atividades e exerce alguma liderança em questões de interesse da comunidade. Existe envolvimento } \\
\text { de pessoas em esforços de desenvolvimento social. }\end{array}$ \\
\hline 4 & $\begin{array}{c}\text { O processo de avaliação dos impactos das atividades da organização está em fase de sistematização. } \\
\text { A organização exerce liderança em questões de interesse da comunidade de diversas formas. O } \\
\text { envolvimento das pessoas em esforços do desenvolvimento social é frequente. A organização } \\
\text { promove o comportamento ético. }\end{array}$ \\
\hline 5 & $\begin{array}{c}\text { O processo de avaliação dos impactos das atividades da empresa está sistematizado, buscando } \\
\text { antecipar as questões públicas. A organização lidera questões de interesse da comunidade e do setor. } \\
\text { O estímulo à participação das pessoas em esforços de desenvolvimento social é sistemático. Existem } \\
\text { formas implementadas de avaliação e melhoria da atuação da organização no exercício da cidadania } \\
\text { e no tratamento de suas responsabilidades públicas. É o estágio mais avançado e deve ser } \\
\text { considerado como meta da organização. }\end{array}$ \\
\hline
\end{tabular}

FONTE: TACHIZAWA, 2002, p. 85.

\subsubsection{Indicadores de Desempenho Social}

Clarkson (1995) destaca que a principal questão na avaliação do desempenho da organização está relacionada à obtenção de dados para mensuração. Dados e indicadores de desempenho descrevem o que a empresa faz em relação a assuntos específicos. $O$ fato da empresa não dispor de determinadas informações indica sua postura em relação aos respectivos assuntos. Se os dados não estão disponíveis, os assuntos não podem ser gerenciados. Os dados passam a ser monitorados e gerenciados na medida em que a empresa atribui importância e relevância que justifique o acompanhamento. Além disso, quanto mais alto o nível de gestão ao qual os dados são reportados, maior o indício da importância atribuída pela organização ao assunto.

Hammond et al. (1995) apontam que os indicadores quantificam a informação para seu significado ser prontamente evidente e simplificam informações de fenômenos complexos para melhorar a comunicação. Os indicadores possuem as funções de reduzir o número de medidas e parâmetros que, normalmente, seriam requeridos para apresentar uma situação e de simplificar o processo de comunicação pelo qual os resultados da mensuração são oferecidos aos usuários.

A GRI define indicadores de desempenho como "informações qualitativas ou quantitativas sobre consequências ou resultados associados à organização que sejam comparáveis e possam 
mostrar mudanças ao longo do tempo" (GRI, 2012). De acordo com a Organisation for Economic Co-operation and Development (OECD), um indicador é "uma medida qualitativa ou quantitativa derivada de uma série de fatos observáveis que pode revelar posições relativas em uma determinada área". Quando avaliado em intervalos regulares, um indicador pode apontar direções de mudanças em diferentes unidades e ao longo do tempo (OECD, 2012).

O modelo de relatório de comunicação do desempenho social, ambiental e econômico mais difundido, atualmente, é o GRI, criado, em 1997, pela organização não governamental de mesmo nome. A GRI foi fundada pela Coalition for Environmentally Responsible Economies (CERES) e pelo Programa das Nações Unidas para o Meio Ambiente (UNEP), em Boston, nos Estados Unidos. Atualmente, a sede da GRI é em Amsterdã e conta com representantes regionais - os Pontos Focais - na Austrália, Brasil, China, Índia e Estados Unidos, e uma rede mundial de 30.000 pessoas.

De acordo com a instituição, elaborar relatórios de sustentabilidade é a prática de medir, divulgar e prestar contas, para stakeholders internos e externos, do desempenho organizacional visando ao desenvolvimento sustentável. "Relatório de Sustentabilidade" é um termo amplo considerado sinônimo de outros relatórios cujo objetivo é descrever os impactos econômicos, ambientais e sociais de uma organização, como o relatório de responsabilidade social empresarial, o balanço social etc. Esse tipo de documento deve oferecer uma descrição equilibrada e sensata do desempenho de sustentabilidade da organização relatora, incluindo informações tanto positivas como negativas. (GRI, 2012)

Entre outros propósitos, o relatório pode ser usado como:

a) padrão de referência (benchmarking) e avaliação do desempenho de sustentabilidade com respeito a leis, normas, códigos, padrões de desempenho e iniciativas voluntárias;

b) demonstração de como a organização influencia e é influenciada por expectativas de desenvolvimento sustentável;

c) comparação de desempenho dentro da organização e entre organizações diferentes ao longo do tempo.

Segundo as diretrizes do relatório, as informações a serem divulgadas, que são relevantes e essenciais para a maioria das organizações e do interesse da maior parte dos stakeholders, podem ser divididas em três categorias de conteúdo: 
a) perfil: informações que estabelecem o contexto geral para a compreensão do desempenho organizacional, tais como sua estratégia, perfil e governança;

b) forma de gestão: conteúdo que descreve o modo como a organização trata determinado conjunto de temas para fornecer o contexto para a compreensão do desempenho em uma área específica;

c) indicadores de desempenho: informações comparáveis sobre o desempenho econômico, ambiental e social da organização.

De acordo com a GRI, seu objetivo é elevar as práticas de relatórios de sustentabilidade a um nível de qualidade equivalente ao dos relatórios financeiros. O conjunto de diretrizes e indicadores pode proporcionar a comparabilidade, credibilidade, periodicidade e legitimidade da informação na comunicação do desempenho social, ambiental e econômico das organizações. Atualmente, mais de 1000 empresas produzem seus relatórios com base na terceira geração do modelo GRI-G3, sendo 60 delas brasileiras (GRI, 2012). De acordo com a empresa KMPG (2011), 80\% das 250 maiores empresas mundiais utilizam os padrões do GRI para elaborar seus relatórios. A Ilustração 3 se refere aos princípios para elaboração do relatório de sustentabilidade ou relatório de RSC de acordo com o modelo do GRI. 


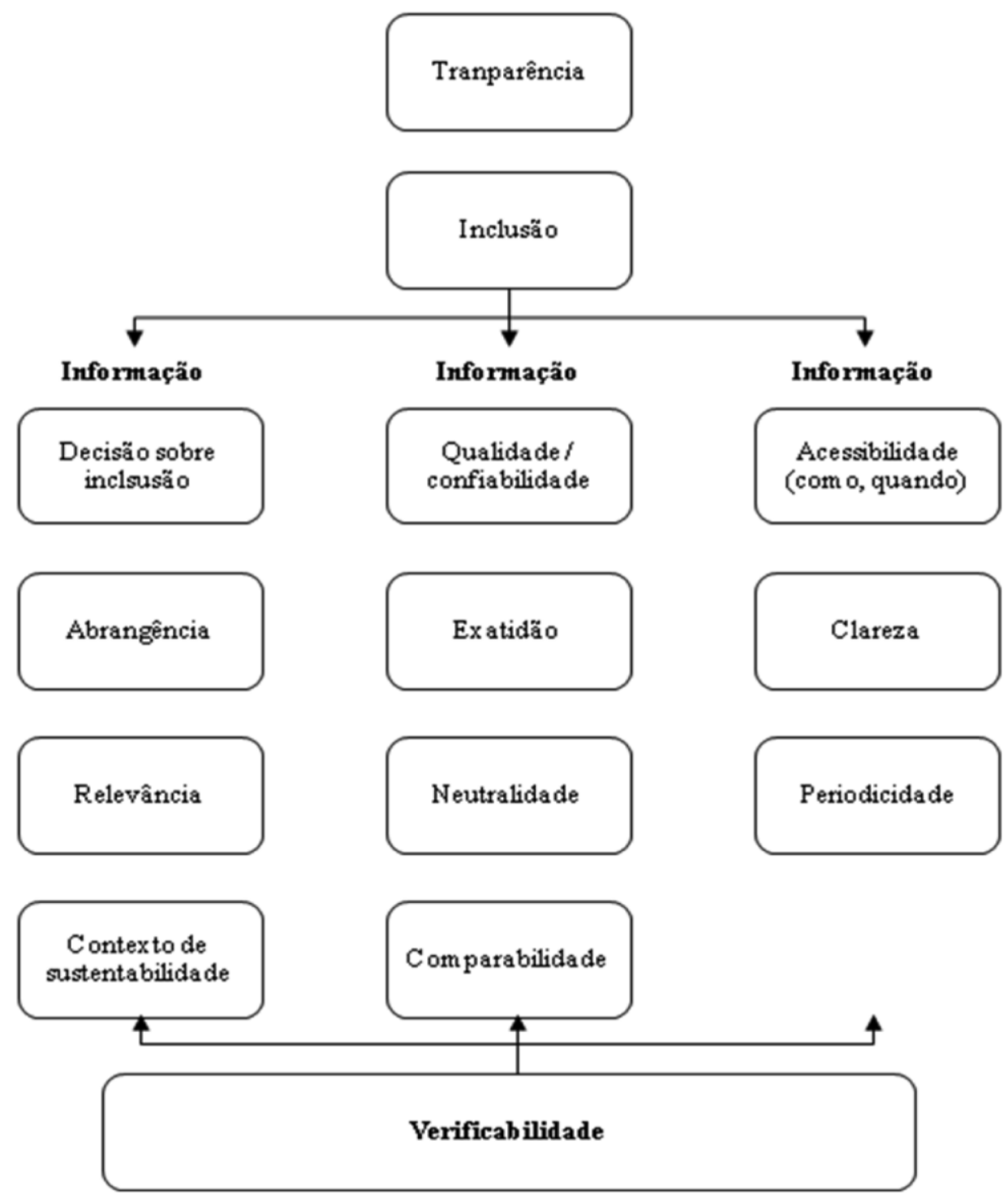

Ilustração 3 - Princípios para elaboração do relatório de sustentabilidade/RSC de acordo com o modelo do GRI.

FONTE: GRI, 2012.

No Brasil, além do relatório do GRI, podem-se citar os Indicadores Ethos de Responsabilidade Social. Os Indicadores Ethos são formados por meio de um questionário cujo preenchimento é feito internamente pela empresa, a partir de um processo que envolve diferentes áreas e níveis hierárquicos. As respostas são passadas para um sistema on-line que calcula os desempenhos para cada indicador e os apresenta em um relatório final, chamado de Relatório de Diagnóstico. Além dos desempenhos, o sistema calcula médias comparativas para servirem de referências às empresas. O banco de dados é formado por informações de todas as empresas que responderam o questionário, e a média do grupo de benchmark é formada pelo desempenho das empresas que obtiveram as dez melhores colocações. (INSTITUTO ETHOS, 2012) 


\subsubsection{Padrões e Certificadores de RSC}

No intuito de estimular a RSC, uma série de padrões e certificadores foi criada nos últimos anos por organizações como a International Organization for Standardization (ISO). A ISO é uma organização internacional de normalização, com sede em Genebra, na Suíça. Foi criada em 1946 e tem como associados órgãos de normalização de cerca de 160 países. A ISO tem como objetivo declarado criar normas que facilitem o comércio e promovam boas práticas de gestão e o avanço tecnológico, além de disseminar conhecimentos. Sua representante no Brasil é a Associação Brasileira de Normas Técnicas (ABNT). Dentre suas diversas normas, a ISO criou a série ISO 14000, que estabelece requisitos para gestão ambiental no desenvolvimento das atividades da empresa. A avaliação para certificação é feita por empresas certificadoras reconhecidas e observam os seguintes itens: cumprimento da legislação ambiental; diagnóstico atualizado dos impactos ambientais gerados; procedimentos- padrão e planos de ação para eliminar ou diminuir impacto; pessoal treinado e qualificado (ISO, 2012).

A partir de 2001, a ISO iniciou um processo de avaliação da viabilidade de elaboração de uma norma referente especificamente ao tema Responsabilidade Social. A ABNT decidiu, em dezembro de 2002, constituir uma comissão formada por representantes de diversas partes interessadas, como: governo, setor produtivo, ONGs, entidades de classe e academia, para elaborar uma norma nacional de Responsabilidade Social. A Norma Brasileira, a NBR 16001, foi publicada em dezembro de 2004 e estabelece requisitos mínimos relativos a um sistema de gestão da responsabilidade social, permitindo à organização formular e implementar uma política e objetivos que levem em conta as exigências legais, seus compromissos éticos e sua preocupação com a promoção da cidadania e do desenvolvimento sustentável, além da transparência das suas atividades. As organizações devem desenvolver programas (com objetivos e metas) que deverão contemplar onze temas da Responsabilidade Social: boas práticas de governança; combate à pirataria, sonegação, fraude e corrupção; práticas leais de concorrência; direitos da criança e do adolescente, incluindo o combate ao trabalho infantil; direitos do trabalhador, incluindo o de livre associação, de negociação, a remuneração justa e benefícios básicos, bem como o combate ao trabalho forçado; promoção da diversidade e combate à discriminação (por exemplo: cultural, de gênero, de raça/etnia, idade, pessoa com deficiência); compromisso com o desenvolvimento profissional; promoção da saúde e segurança; promoção de padrões sustentáveis de desenvolvimento, produção, distribuição e 
consumo, contemplando fornecedores, prestadores de serviço, entre outros; proteção ao meio ambiente e aos direitos das gerações futuras; ações sociais de interesse público. (INMETRO, 2012)

Mais recentemente, em novembro de 2010, foi publicada a ISO 26000 - Diretrizes sobre Responsabilidade Social, em Genebra, Suíça. No Brasil, no dia 8 de dezembro de 2010, a versão em português da norma, a ABNT NBR ISO 26000, foi lançada em evento na Federação das Indústrias do Estado de São Paulo (FIESP). De acordo com a ISO 26000, a responsabilidade social se expressa pelo desejo e pelo propósito das organizações em incorporar considerações socioambientais em seus processos decisórios e em responsabilizarse pelos impactos de suas decisões e atividades na sociedade e no meio ambiente. De acordo com a ISO (2012), isso implica um comportamento ético e transparente que contribua para o desenvolvimento sustentável, que esteja em conformidade com as leis aplicáveis e seja consistente com as normas internacionais de comportamento. Também implica que a responsabilidade social esteja integrada em toda a organização, seja praticada em suas relações e leve em conta os interesses das partes interessadas. A norma fornece orientações para todos os tipos de organização, independente de seu porte ou localização, sobre:

a) conceitos, termos e definições referentes à responsabilidade social;

b) histórico, tendências e características da responsabilidade social;

c) princípios e práticas relativas à responsabilidade social;

d) temas centrais e questões referentes à responsabilidade social;

e) integração, implementação e promoção de comportamento socialmente responsável em toda a organização e por meio de suas políticas e práticas dentro de sua esfera de influência;

f) identificação e engajamento de partes interessadas;

g) comunicação de compromissos, desempenho e outras informações referentes à responsabilidade social.

De acordo com o INMETRO (2012), a ISO 26000:2010 é uma norma de diretrizes e de uso voluntário, e não visa nem é apropriada a fins de certificação.

Além das normas da ISO, podem-se citar outras normas bastante difundidas como: 
a) SA 8000 (Social Accountability 8000): criada em 1997, tem foco nas relações trabalhistas e fornece um sistema de implementação, manutenção e verificação de condições dignas de trabalho. Baseada nas normas da International Labour Standards Convention, da Declaração Universal dos Direitos Humanos e da Convenção dos Direitos da Criança, avalia alguns quesitos específicos que são: trabalho infantil; trabalho forçado; saúde e segurança; discriminação; práticas disciplinares; horários de trabalho; remuneração; sistema de gestão.

b) BS 8800 (British Standards 8800): norma relativa ao Sistema de Gestão da Segurança e da Saúde no trabalho. É um guia de diretrizes bastante genérico que se aplica tanto a indústrias complexas, de grande porte e altos riscos, como a organizações de pequeno porte e baixos riscos. Levou cerca de 15 meses para ser discutida e aprovada oficialmente, entrou em vigor no dia 15 de maio de 1996. A norma BS 8800 foi traduzida para o português e adaptada e ajustada à terminologia utilizada no Brasil.

c) AA1000 (AccountAbility 1000): criada em 1996 pelo Institute of Social and Ethical Accountability, com sede em Londres, foi desenvolvida para melhorar a prestação de contas e a qualidade da contabilidade, auditoria e relatórios de questões sociais e éticas. Uma de suas principais características é o caráter evolutivo, pois, a avaliação é feita anualmente.

Pode-se citar, como exemplo de certificador criado no Brasil, o Selo Empresa Amiga da Criança, da Fundação Abrinq, que é oferecido a empresas que não utilizam mão-de-obra infantil e contribuem para a melhoria das condições de vida de crianças e adolescentes.

As empresas buscam a certificação por muitas razões, por exemplo, pode: ser um requisito contratual ou regulamentar; ser necessário para atender as preferências dos clientes; cair dentro do contexto de um programa de gestão de riscos; e ajudar a motivar o pessoal, definindo uma meta clara para o desenvolvimento de seu sistema de gestão. (ISO, 2012)

O apelo relacionado a esses selos ou certificados está relacionado às vantagens competitivas que as empresas podem obter ao adquirir certificações que atestem sua "responsabilidade", o que pode diferenciá-las de seus competidores. A busca por esses selos ou certificados faz que 
as empresas adotem processos de reformulação interna para se adequarem às normas impostas pelas entidades certificadoras.

\subsubsection{Desempenho Social Corporativo (DSC) versus Desempenho Financeiro Corporativo (DFC)}

Os impactos econômicos do DSC provocam um debate com visões antagônicas. Por um lado, alguns autores afirmam que a regulamentação socioambiental melhora o desempenho econômico e, por outro lado, há a visão de que os regulamentos são geradores de custos que as empresas nunca vão recuperar, representando desvios financeiros. (RUSSO; FOUTS, 1997)

Diversos estudos em Administração sobre RSC tentam relacionar Desempenho Social e Desempenho Financeiro, o que demonstraria benefícios para as empresas ao se engajarem neste tipo de atividade (McWILLIAMS, SIEGEL, 2011), porém, os resultados encontrados são ambíguos. Enquanto algumas pesquisas constataram uma relação positiva entre DSC e DFC, outras não acharam nenhuma ligação e, ainda, outras mostraram uma relação negativa (McWILLIAMS et al., 2006; CRANE et al., 2008). A inconsistência desses achados pode estar relacionada à inconsistência na própria definição de RSC e nas diferentes formas usadas para medir o desempenho empresarial (McWILLIAMS et al., 2006; MADARIAGA; CREMADES, 2010).

Russo e Fouts (1997) testaram a relação entre DSC e DFC, utilizando dados de 243 empresas em dois anos - 1991 e 1992. Os autores chegaram à conclusão de que o DSC influencia o DFC e que essa relação se fortalece conforme o crescimento da indústria. A explicação dada pelos autores para a relação positiva entre as duas variáveis está baseada em: a) ativos físicos e tecnologia; b) recursos humanos e capacidades organizacionais; c) recursos intangíveis.

Christmann (2000) realizou um estudo empírico para verificar se melhores práticas de gerenciamento ambiental podem reduzir custos e conduzir a vantagens estratégicas. A pesquisa foi realizada com 49 empresas e mostrou que as firmas que possuem ativos complementares e utilizam estratégias ambientais criam vantagens competitivas. $\mathrm{O}$ autor afirma que as empresas bem conduzidas e lucrativas podem ganhar vantagem de custo por 
meio da utilização de estratégias ambientais, pois aproveitam de forma mais eficiente os seus recursos e ativos.

King e Lenox (2001) analisaram 652 empresas de manufatura dos Estados Unidos, durante o período de 1987 a 1996. Apesar de encontrarem evidências de associação entre menor poluição e maior valorização financeira, os autores acreditam que as outras características permanentes das empresas e suas posições estratégicas podem ter causado a associação. Talvez, apenas empresas com certos atributos possam lucrar implementando estratégias ambientais. Os resultados sugerem que se deve ter cautela ao analisar as relações entre DSC e DFC, pois há outras características das empresas que podem estar influenciando esses resultados.

McWilliams e Siegel (2000) afirmaram que os modelos criados para medir o impacto do DSC no DFC estão incompletos, pois não incluem variáveis importantes como investimento em pesquisa e desenvolvimento e intensidade de propaganda da indústria. Os estudos estimam esse impacto por meio da técnica de regressão, controlando algumas variáveis, porém não controlam a variável pesquisa e desenvolvimento, por exemplo, que, segundo os autores, tem se mostrado uma importante variável na determinação do desempenho da empresa. Os autores utilizaram uma série de dados de 524 empresas no período de 1991 a 1996. Os resultados mostraram que pesquisa e desenvolvimento, desempenho social e desempenho financeiro são fortemente correlacionados, mas quando pesquisa e desenvolvimento e fatores da indústria são adicionados ao modelo não se observa uma relação estatisticamente significante.

Surroca et al. (2010) afirmam que os recursos intangíveis da empresa, incluindo inovação, recursos humanos, reputação e cultura organizacional são variáveis mediadoras entre DSC e DFC. Para esses autores, a RSC terá um efeito positivo no desempenho da empresa caso possibilite o desenvolvimento de recursos intangíveis, relacionados à inovação, recursos humanos, reputação e cultura organizacional, caso contrário poderá ter efeitos neutros e até mesmo negativos. Além disso, a relação causal inversa também existe e o maior desempenho financeiro leva ao desenvolvimento desses recursos e, consequentemente, ao aumento no desempenho social. Portanto, há uma relação indireta entre os dois desempenhos, mediada pelos recursos intangíveis da empresa. Os autores chamaram o fenômeno de circulo virtuoso, 
no qual qualquer aumento em um tipo de desempenho é traduzido em um aumento no outro, somente se novos recursos intangíveis forem desenvolvidos.

Por meio de uma meta análise das pesquisas empíricas que buscaram testar a relação entre Desempenho Social e Desempenho Financeiro, Orlitzky et al. (2003) chegaram à conclusão de que há uma relação positiva entre ambos. A análise sugere que atividades geradas por meio do Desempenho Social e do Desempenho Financeiro são mutualmente reforçadas, e que um pode prever o outro e vice-versa. Em outras palavras, os autores sugerem que a empresa pode desenvolver relações mutualmente benéficas com grupos de stakeholders e empresas socialmente responsáveis podem ser financeiramente recompensadas. Os efeitos financeiros positivos podem se transformar em mais recursos disponíveis para futuros investimentos em Desempenho Social.

Ressalta-se que esses trabalhos são focados, quase exclusivamente, em empresas americanas (SURROCA et al., 2010). No Brasil, poucos estudos foram feitos com a tentativa de demonstrar uma relação entre as duas variáveis. Silva e Quelhas (2006) analisaram o impacto da adoção dos princípios de sustentabilidade no Custo de Capital Próprio de empresas. Os resultados do modelo, testado em dois períodos (2000 a 2002 e 2003 a 2005), confirmaram que com adoção de práticas de sustentabilidade há uma redução do risco sistemático, embora estatisticamente significante somente no primeiro período analisado. Em outras pesquisas (BEATO et al., 2009; REIS et al., 2009), comparou-se o comportamento do ISE com o Índice da Bolsa de Valores de São Paulo (IBOVESPA), buscando-se diferenças no desempenho destes índices. No entanto, os resultados encontrados mostraram comportamento semelhante.

\subsection{Gestão Estratégica da RSC}

\subsubsection{Responsabilidade Social Corporativa Estratégica}

Responsabilidade Social Corporativa Estratégica é a inserção da variável socioambiental ao longo de todo o processo gerencial de planejar, organizar, dirigir e controlar, utilizando-se das funções organizacionais como marketing, produção, finanças, recursos humanos e outras, bem 
como das interações que ocorrem no ecossistema do mercado, visando a atingir os objetivos e metas organizacionais. (NASCIMENTO et al., 2008)

Em meados dos anos 1980 surgiu a abordagem dos stakeholders para a Administração Estratégica. Ela foi desenvolvida como uma resposta direta às preocupações dos gestores geradas pelos níveis crescentes de complexidade e mudanças no ambiente externo. A abordagem dos stakeholders para a administração estratégica vê a empresa como centro de uma rede de grupos e indivíduos que afetam ou são afetados pelas suas atividades. Segundo esse autor, as empresas podem obter vantagem competitiva por meio do gerenciamento superior de stakeholders. Ao aumentar os grupos e indivíduos interessados para os quais a atenção da empresa se dirige, a complexa natureza da tarefa gerencial será representada mais acuradamente. Essa acurácia é importante para que os gestores entendam as diversas forças que influenciam o comportamento e o sucesso organizacional. Além disso, a consideração de um grupo mais amplo de stakeholders durante o processo de administração estratégica pode evitar que a organização seja surpreendida por um stakeholder insatisfeito. Por exemplo, considerar as necessidades de uma comunidade local pode evitar cobertura indesejada na imprensa, processos e legislação adversa. Finalmente, o modelo da abordagem dos stakeholders apresenta mais opções de escolha na seleção de estratégias. (HARRISON, 2005)

Baron (2001) defende que caso a motivação da empresa seja servir à sociedade, mesmo em detrimento dos lucros, então a ação deve ser considerada socialmente responsável, mas caso a motivação seja servir aos lucros, então a ação deve ser considerada privadamente responsável. Para essas últimas ações, poderá haver benefícios sociais que excedam o custo das ações das firmas, porém não mudam a motivação. Por exemplo, disponibilizar creche pode diminuir o número de crimes realizados por jovens, mas a empresa pode disponibilizar a creche somente porque aumenta a frequência dos trabalhadores e diminui os custos com absenteísmo. McWilliams e Siegel (2011) defendem que, apesar dessa distinção ser razoável, não é viável, pois não seria possível determinar a real motivação dos gestores. A partir desse pressuposto, McWilliams e Siegel (2011, p. 1481) consideram que RSC Estratégica seja "qualquer atividade responsável que permita a firma atingir vantagem competitiva sustentável, independentemente da motivação dos gestores”. 
Mintzberg (1983) argumenta que as empresas podem ser recompensadas, em um sentido econômico e financeiro, ao se engajarem em práticas de RSC, porém somente até certo limite. Após um determinado valor de investimentos em RSC, o mercado deixa de recompensar esses investimentos. O mercado de ações está disposto a recompensar a responsabilidade social das empresas somente até um ponto e "vale a pena ser bom, mas não muito bom". (MINTZBERG, 1983, p. 10)

Segundo Karnani (2011) a ideia de que as empresas podem obter lucrar "fazendo o bem" chamou a atenção de executivos, acadêmicos e governantes e é baseada na alegação de que as empresas têm uma responsabilidade social e podem exercê-la sem sacrifícios financeiros. Porém, para o autor, essa afirmação é enganosa. Se os mercados estão funcionando bem, não há necessidade de recorrer a empresas para cumprir uma responsabilidade social vaga e, se houver falha de mercado, então surge um trade-off entre lucros privados e interesse público e, nesse caso, não é desejável nem eficaz confiar na boa vontade dos gestores para maximizar o bem-estar social. Para o autor, quando os mercados falham, algumas restrições devem ser impostas às empresas, as quais podem surgir da responsabilidade social corporativa, da indústria de autorregulação, do ativismo da sociedade civil e da regulação governamental.

Existe uma interdependência entre a empresa e a sociedade. Essa dependência mútua significa que tanto decisões empresariais quanto políticas sociais podem seguir o princípio do valor compartilhado, trazendo benefícios para os dois lados. A interdependência da empresa e da sociedade assume duas formas. A primeira é a de dentro para fora, em que a empresa afeta a sociedade por meio de suas atividades na cadeia de valor. A segunda é a de fora para dentro, em que as condições externas exercem influência sobre as empresas, é o chamado contexto competitivo. (PORTER; KRAMER, 2006)

A empresa pode valer-se de iniciativas filantrópicas para melhorar seu contexto competitivo a qualidade do ambiente de negócios no local, ou locais, em que opera. Recorrer à filantropia para melhorar o contexto competitivo implica um alinhamento das metas sociais com as metas econômicas e pode melhorar as perspectivas comerciais de longo prazo. O contexto competitivo sempre foi importante para a Estratégia, pois variáveis contextuais, tais como: disponibilidade de funcionários capacitados e motivados; eficiência da infraestrutura local; tamanho e sofisticação do mercado local; escopo da regulamentação governamental, afetam a capacidade competitiva. Ao analisar os elementos do contexto competitivo, a empresa pode 
identificar as áreas em que o valor social coincide com o econômico e que mais irão beneficiar a sua própria competitividade e do seu polo, buscando o benefício social combinado com o econômico, conforme mostrado na Ilustração 4. (PORTER; KRAMER, 2002)

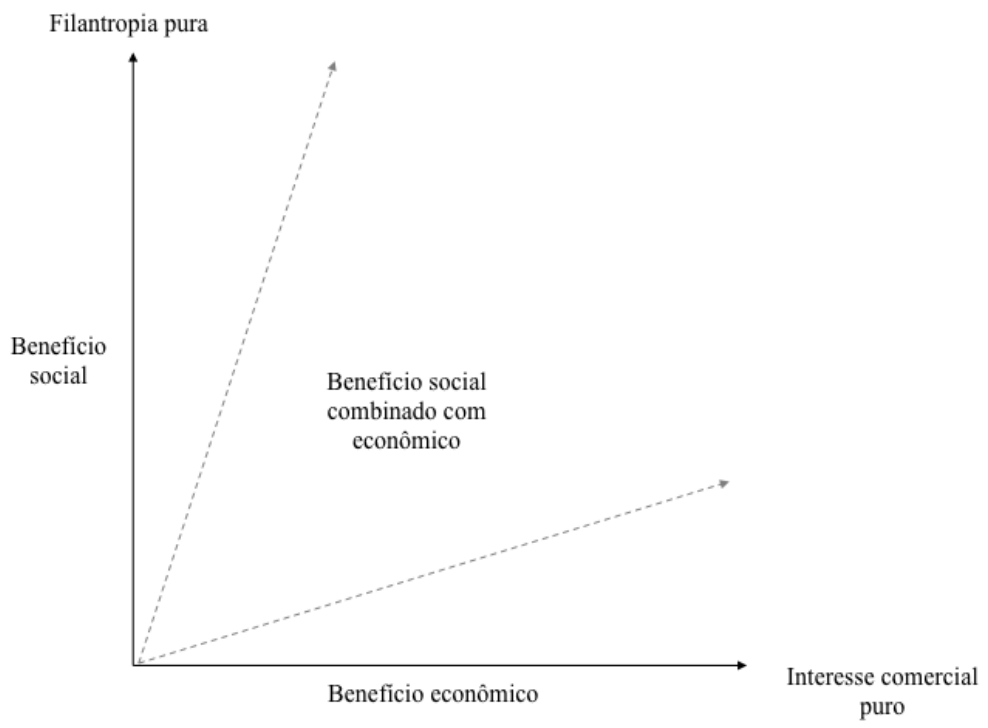

Ilustração 4 - Convergência de interesse comercial e social. FONTE: PORTER; KRAMER, 2002, p. 45.

Normalmente, as contribuições sociais das empresas refletem crenças e valores pessoais de executivos ou funcionários, em vez de estarem vinculadas a objetivos sociais ou empresariais bem formulados (PORTER; KRAMER, 2002). As abordagens dominantes à RSC são tão fragmentadas e desvinculadas da empresa e da estratégia que ocultam muitas das grandes oportunidades para que a empresa beneficie a sociedade. Se as perspectivas no campo da responsabilidade social forem analisadas com os mesmos arcabouços que norteiam as principais decisões empresariais, a RSC "pode ser muito mais do que um custo, um entrave ou ação filantrópica - pode ser uma fonte de oportunidades, inovação e vantagem competitiva". (PORTER; KRAMER, 2006, p.54)

Segundo o modelo de Porter e Kramer (2006), as questões sociais que afetam a empresa podem ser divididas em três categorias: a) questões sociais genéricas: podem ser importantes para a sociedade, mas não são fortemente afetadas pelas operações da empresa nem influenciam sua competitividade em longo prazo; b) impactos sociais da cadeia de valor: são afetados de forma significante pelas atividades da empresa no curso normal das operações; c) 
dimensões sociais do contexto competitivo: são fatores do ambiente externo que afetam de modo considerável a natureza da competitividade nos locais em que a empresa opera.

Por meio dessa divisão, a empresa pode classificar as questões sociais nas três categorias e analisar seus potenciais impactos. Uma mesma questão social pode ser considerada genérica para uma empresa, mas ser parte importante do contexto competitivo de outra. Mesmo questões que atingem toda a economia, como a diversidade na contratação ou a conservação de energia, podem ser mais relevantes para certos setores. E, finalmente, em setor, uma mesma questão social pode ter impacto distinto para distintas empresas, devido a diferenças no posicionamento competitivo. (PORTER; KRAMER, 2006)

A empresa deve se concentrar em questões que tenham alguma interseção com sua área de atuação e, em geral, quanto maior o vínculo da questão social com sua atividade, maior a oportunidade de alavancar recursos em benefício da sociedade. O Quadro 6 mostra a diferença entre RSC responsiva e RSC estratégica.

Quadro 6- Envolvimento da empresa na sociedade: abordagem estratégica.

\begin{tabular}{|c|c|c|}
\hline $\begin{array}{l}\text { Impacto social } \\
\text { genérico }\end{array}$ & $\begin{array}{l}\text { Impactos sociais da cadeia } \\
\text { de valor }\end{array}$ & $\begin{array}{l}\text { Dimensões sociais do } \\
\text { contexto competitivo }\end{array}$ \\
\hline Boa cidadania & $\begin{array}{l}\text { Mitigar danos causados por } \\
\text { atividades da cadeia de valor }\end{array}$ & $\begin{array}{l}\text { Filantropia estratégica } \\
\text { que alavanca recursos } \\
\text { para melhorar áreas } \\
\text { relevantes do contexto } \\
\text { competitivo }\end{array}$ \\
\hline $\begin{array}{l}\text { RSC } \\
\text { responsiva }\end{array}$ & $\begin{array}{l}\text { Transformar atividades da } \\
\text { cadeia de valor para } \\
\text { beneficiar a sociedade e ao } \\
\text { mesmo tempo fortalecer a estratégia }\end{array}$ & $\begin{array}{l}\text { RSC } \\
\text { estratégica }\end{array}$ \\
\hline
\end{tabular}

FONTE: PORTER; KRAMER, 2006, p.63.

Burke e Logsdon (1996) desenvolveram um conceito de RSC estratégica identificando cinco dimensões de atividades de RSC que permitem servir aos interesses econômicos da empresa, assim como aos interesses de seus stakeholders. Atividades caracterizadas por: alta 
centralidade, especificidade, proatividade, voluntarismo e visibilidade têm maiores probabilidades de criar valor para a empresa.

De acordo com Husted e Allen (2001), a relação entre responsabilidade social e desempenho econômico não ocorre com a simples inclusão de programas de responsabilidade social, mas, sim, quando é cuidadosamente desenhada. Os autores criaram um modelo, apresentado na Ilustração 5, para formular a estratégia de responsabilidade social baseado em quatro elementos:

a) estrutura da indústria: a vantagem competitiva é alcançada pela superioridade em um ou mais dos seis fatores competitivos - atributos do produto, imagem do produto, design, preço, serviço ou reputação organizacional. A possibilidade de diferenciação social existe porque há consumidores que fazem decisões de compra, baseadas no Desempenho Social da empresa. A estratégia de diferenciação social é bem sucedida quando os consumidores estão dispostos a pagar um preço premium por produtos sociais e quando são criadas barreiras aos competidores (REINHARDT, 1998).

b) recursos internos da firma: incluem não somente os tradicionais recursos tangíveis, mas também recursos intangíveis, como capital humano, social e reputacional. Esses recursos são desenvolvidos ao longo do tempo, conforme a empresa interage com todos os seus stakeholders. A aplicação desses recursos para oportunidades de mercado e oportunidades sociais representa para cada empresa um posicionamento único e dinâmico. (EISENHARDT, 2000)

c) ideologia e valores organizacionais: as interpretações dos gestores sobre assuntos sociais e ambientais afetam diretamente a seleção das estratégias sociais. Um forte comprometimento com responsabilidade social promove um conjunto de valores que não são fáceis de serem imitados. (BARNEY, 1986)

d) relacionamento com stakeholders: as pessoas e grupos de pessoas que afetam e são afetadas pela empresa formam a estrutura social na qual a empresa opera e determinam por quem ela é responsável. A interação com stakeholders cria temas sociais que promovem oportunidades e ameaças em relação às quais as empresas se posicionam. 


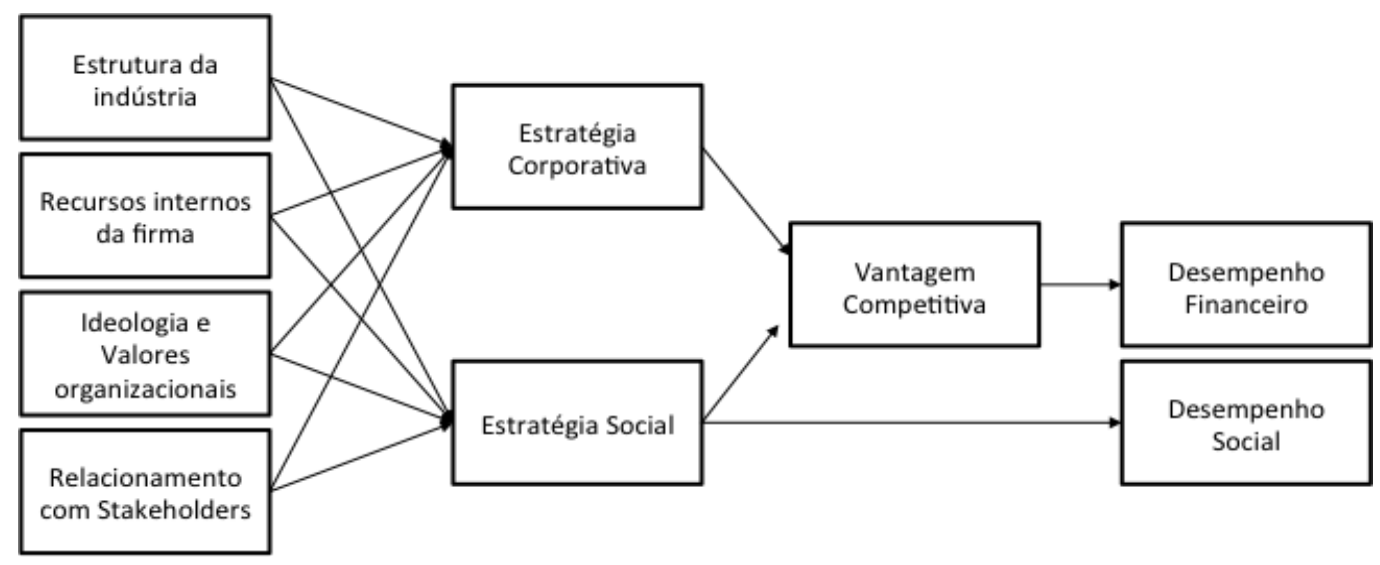

Ilustração 5 - Visão integrada da estratégia corporativa e social. FONTE: HUSTED; ALLEN, 2001, p. 26.

Na mesma lógica, Fombrum et al. (2000) enxergam a RSC como uma ferramenta estratégica com a qual a empresa pode gerir tanto ganhos reputacionais, que possibilitam atrair recursos, melhorar o desempenho e construir vantagem competitiva, quanto as perdas reputacionais, que resultam da alienação de seus stakeholders. Não é possível estabelecer uma simples relação entre Desempenho Social e Desempenho Financeiro, e as atividades de RSC não geram impacto direto no desempenho financeiro, mas afetam o bottom line por intermédio do estoque de capital reputacional.

Molteni (2006) desenvolveu um modelo com cinco níveis para investigar os graus de eficiência com que a empresa lida com as necessidades sociais. $\mathrm{O}$ mais alto é chamado de "síntese de competitividade social", em que as necessidades sociais podem ser integradas à estratégia corporativa, e o nível mais baixo é chamado de "sacrifício temporário das expectativas sociais", é aquele em que as expectativas sociais são sacrificadas na estratégia corporativa. Uma das dificuldades encontradas pela empresa é a identificação das expectativas dos stakeholders, uma vez que as repercussões sociais de uma nova estratégia ainda não foram testadas. Entretanto, na visão desse autor, a gestão pode criar um diálogo preliminar com os stakeholders, reforçando sua capacidade de prever os problemas sociais e ambientais. Após a identificação das expectativas, é possível encontrar soluções inovadoras para atendê-las, e a RSC pode se tornar um fator criativo para o desenvolvimento da competitividade da empresa. 
No entanto, enquanto esses desafios exigem inovação, a maioria das empresas continua a se concentrar em estratégias incrementais como ecoeficiência, prevenção da poluição e gestão de produtos (HART; DOWELL, 2011). Tais estratégias incrementais de RSC não são suficientes para que o Desempenho Social impacte na geração de valor para a empresa.

\subsubsection{RSC à luz da Resource Based View}

A utilização da RSC de forma estratégica pela empresa pode ser analisada através da lente da Visão Baseada em Recursos ou Resource Based View (RBV). A RBV surgiu da frustração com o paradigma estrutura-conduta-desempenho da Organização Industrial, que afirmava que o sucesso da empresa era determinado exclusivamente pelo seu ambiente externo. Os teoristas dessa nova visão consideravam que o paradigma da Organização Industrial era irrealista e limitado, e se voltaram ao trabalho de Penrose (1959) para criar uma nova explicação para o desempenho das empresas. Wernerfelt (1984), Barney (1986), Dierickx e Cool (1989) e Prahalad e Hamel (1990) construíram a visão baseada em recursos em torno das competências internas das empresas. Para essa teoria, a vantagem competitiva está enraizada na empresa. As capacidades ou competências e habilidades gerenciais para reunir esses ativos para produzir desempenho superior determinam a vantagem competitiva. (GRANT, 1991)

A geração de vantagem competitiva ocorre pela implementação de uma estratégia que agregue valor e gere benefícios para a empresa, sem que outra concorrente simultaneamente o faça. Ela pode ser atingida por meio de recursos internos ou de conjuntos de recursos internos da firma. Para isso, os recursos devem ser: a) valiosos - aqueles que exploram as oportunidades e neutralizam as ameaças do ambiente da firma; b) raros - aqueles escassos e que não estão presentes em nenhuma empresa concorrente ou potencialmente concorrente; c) imperfeitamente imitáveis - aqueles que não podem ser imitados; d) insubstituíveis - aqueles que não possuem equivalente estratégico (BARNEY, 1991).

Hart (1995) afirma que a teoria da RBV considera uma série de recursos potenciais e tem uma lógica que é mais convincente e mais completa do que as tentativas anteriores de explicar a vantagem competitiva, porém, ela ignora a interação entre a organização e o seu ambiente natural. A partir dessa afirmação, o autor propôs a Natural Resource Based View (NRBV), na qual o ambiente natural pode criar restrições sobre as tentativas da organização de criar 
vantagem competitiva sustentável. O autor afirma que a tendência é de que a Estratégia e a vantagem competitiva estejam baseadas cada vez mais em atividades econômicas ambientalmente sustentáveis.

Na lógica da NRBV, existem três principais capacidades estratégicas: a prevenção da poluição, o gerenciamento de produtos e o desenvolvimento sustentável. A prevenção da poluição visa a prevenir os resíduos e as emissões, e está associada a custos mais baixos. A gestão de produtos expande o escopo da prevenção da poluição para incluir toda a cadeia de valor ou "ciclo de vida" dos sistemas de produtos da empresa. Finalmente, uma estratégia de desenvolvimento sustentável visa a causar menos danos ambientais e produzir de uma maneira que possa ser mantida no futuro, além de envolver questões econômicas e sociais. (HART; DOWELL, 2011)

Russo e Fouts (1997) afirmam que a RBV oferece aos pesquisadores a ferramenta para refinar a análise de como a política social da empresa influencia o "bottom line" por duas razões. Primeiro, a RBV tem forte foco no desempenho como variável-chave. E segundo, da mesma forma que a literatura de responsabilidade social, reconhece explicitamente a importância de conceitos intangíveis, como know-how, cultura corporativa e reputação. Essas complementariedades teóricas oferecem uma oportunidade significativa para destacar a relação entre Desempenho Social e Desempenho Financeiro.

Assim, é possível partir do pressuposto de que a RSC pode ser considerada um recurso interno da empresa. Aplicando-se as definições de Barney (1991) para gerar vantagens competitivas, as ações de RSC devem ser valiosas, raras, inimitáveis e insubstituíveis. Desta forma, atribuindo estas características às ações e estratégias de RSC, podem-se ter recursos que sejam fonte de vantagens competitivas para a empresa. (PESSOA et al., 2009)

É possível afirmar que a RSC seja um conjunto de recursos, pois contempla diferentes dimensões que podem ser consideradas recursos internos, como valores organizacionais, ética nos negócios, relacionamentos com stakeholders, reputação empresarial, dentre outros (PESSOA et al., 2009).

Sob a perspectiva da RBV, a RSC é vista como geradora de benefícios internos, externos ou ambos. Investimentos nessa área podem gerar vantagens internas, ajudando a empresa a 
desenvolver novos recursos e capacidades, relacionados, por exemplo, com know-how e cultura corporativa. Os benefícios externos da RSC estão relacionados com a reputação - um recurso intangível fundamental que pode ser criado ou destruído como consequência da decisão em se engajar ou não em atividades e divulgação de RSC. Empresas com boa reputação em RSC podem ter melhores relacionamentos com atores externos e atrair melhores funcionários, além de aumentar a motivação, moral, comprometimento e lealdade dos atuais funcionários com a empresa. (BRANCO; RODRIGUES, 2006)

Utilizando o modelo da RBV, McWilliams e Siegel (2001) propuseram um modelo de Teoria da Firma de maximização dos lucros para RSC. A Teoria da Firma é um conceito criado pelo economista Ronald Coase, em seu artigo The Nature of the Firm, de 1937. Segundo essa teoria, as firmas atuam com a oferta de mercado, ou seja, com os produtos que vão oferecer aos consumidores, como bens e serviços produzidos. As firmas reúnem o capital e o trabalho para realizar a produção e são responsáveis por agregar valor às matérias-primas utilizadas nesse processo. As empresas produzem conforme a demanda do mercado, e a oferta é ajustada por aqueles que estão dispostos a consumir.

Nesse modelo, duas companhias produzem produtos idênticos, porém uma delas possui um atributo ou característica social adicionada ao seu produto, o que é, potencialmente, valorizada por alguns consumidores ou por outros stakeholders. Então, os gestores analisam o custo-benefício para determinar o nível de recursos que serão alocados para esse atributo ou característica. Eles avaliam a demanda para a RSC e o custo para satisfazer essa demanda. Nessa abordagem, a RSC se torna compatível com a visão de Friedman (1970), pois o nível ótimo de resultado social, em cada situação, é calculado para maximizar o valor ao acionista. (HUSTED; SALAZAR, 2006)

A perspectiva da Teoria da Firma para RSC tem diversas implicações estratégicas. Primeiro, a RSC pode ser integrada nas estratégias de diferenciação da empresa, tanto no nível do negócio como no nível da corporação. Dessa forma, deve ser vista como forma de investimento estratégico. Mesmo quando não é diretamente atrelada a uma característica de um produto ou a um processo de produção, a RSC pode construir ou manter a reputação da empresa. A segunda implicação estratégica dessa perspectiva é que a lógica da RBV pode ser 
aplicada a RSC, uma vez que é possível estabelecer previsões de padrões de investimentos em RSC entre empresas e entre indústrias. McWILLIAMS et al., 2006)

O uso da RSC para diferenciação de produto ocorre quando a maioria dos consumidores prefere um produto a outro. Por exemplo, mantendo-se todas as outras características iguais, a maioria dos consumidores prefere um veículo que utiliza menos combustível. No contexto da RSC, isso ocorre quando é claro na mente do consumidor que o produto com a característica de RSC é melhor do que o produto sem essa característica. Por exemplo, a versão híbrida do Accord Honda gera menos poluição do que o Accord Honda padrão, então, é claro para maioria dos consumidores que o modelo híbrido é melhor do que o modelo padrão e alguns desses consumidores estarão dispostos a pagar um preço premium pelo carro híbrido. Esse tipo de diferenciação pode fortalecer ou manter a reputação da empresa, além de permitir que ela atenda a uma demanda de mercado específica. (McWILLIAMS et al., 2006)

Porém, enquanto os atributos externos gerados pela RSC podem ser avaliados facilmente pelos consumidores, é muito difícil para esses avaliarem se as operações internas da empresa estão de acordo com seus padrões morais e políticos de RSC. O nível de assimetria de informação pode ser mediado pela própria firma ou por ativistas. Muitas empresas publicam relatórios anuais sobre responsabilidade social (KPMG, 2011), porém muitos consumidores podem ver essas informações como enviesadas, uma vez que são filtradas pelos gestores da própria empresa. Fedderson e Gilligan (2001) afirmam que os ativistas podem exercer um papel importante, fornecendo aos consumidores informações em que possam se basear para escolher empresas responsáveis.

A credibilidade é um recurso, particularmente, importante para desenvolver uma estratégia de diferenciação social. Sem informações confiáveis, os consumidores dificilmente pagarão um preço premium para produtos sociais (REINHARDT, 1998). A credibilidade é um elemento essencial para a reputação organizacional, que só é desenvolvida com esforço consistente no longo prazo e contribui para o desempenho financeiro da empresa. (FOMBRUN; SHANLEY, 1990).

Utilizando o modelo de análise de custo-benefício, Husted e Salazar (2006) propuseram uma questão de pesquisa: é melhor as empresas agirem estrategicamente em relação à RSC ou serem coagidas a fazer esses investimentos? Os autores analisaram as condições sob as quais 
as empresas podem maximizar seus lucros e melhorar o desempenho social. Para isso, eles formaram três cenários: altruísta, egoísta e estratégico. O altruísta descreve os casos em que a empresa tem a vontade sincera de agir com responsabilidade social, sem a preocupação de como essas atividades afetam o bottom-line. O egoísta ocorre quando a empresa age de uma maneira socialmente responsável somente quando é coagida por regulamentação ou outros fatores. E, finalmente, o uso estratégico da RSC ocorre quando há claros benefícios para a empresa. Os autores usaram análise microeconômica para determinar o nível ótimo de resultados sociais que provêm de cada um desses três casos. Eles demonstraram que a sociedade e a empresa se beneficiam mais quando as empresas usam a RSC de forma proativa do que quando são coagidas a fazer tais investimentos.

Deve-se ressaltar que uma empresa que se engaja em uma estratégia de RSC, apenas poderá obter retornos acima da média, se ela for capaz de prevenir que seus competidores imitem sua estratégia (REINHERDT, 1998), o que se torna difícil em mercados competitivos, uma vez que as atividades de RSC são transparentes.

Barreiras de entrada podem existir, por exemplo, quando produtos que protejam o meio ambiente são patenteados, ou quando processos socialmente responsáveis são baseados em relações de confiança com fornecedores, e são raros e difíceis de serem imitados (BARNEY, 1986). Além disso, como as relações entre fatores competitivos e estratégias sociais são complexas, criam vantagens competitivas reais e mensuráveis. A estratégia social, normalmente, é determinada por uma trajetória e tem uma natureza ambígua, podendo promover oportunidades mais fortes de inimitabilidade (BARNEY, 1986; PETERAF, 1993). Neste caso, os gestores possuem recursos ou capacidades únicas que lhes permitem empregar estratégias sociais lucrativas, que são difíceis de imitar.

O desenvolvimento da reputação para credibilidade está baseado, em parte, na disposição da empresa em fornecer informações sobre seus impactos sociais e ambientais. A credibilidade desenvolvida por algumas empresas é uma capacidade estratégica, que foi construída dependentemente da sua trajetória, e não pode ser imitada facilmente por seus competidores. Além disso, a consistência da politica de credibilidade é realizada ao longo do tempo e entre diversas esferas, dificultando a imitação. É mais fácil para empresas com esse recurso desenvolver uma estratégia de diferenciação social. (HUSTED; ALLEN, 2001). 


\subsubsection{Geração de Valor para a Empresa}

De acordo com a fundamentação teórica apresentada, podem-se identificar oito principais benefícios que a RSC gera para a empresa, resumidos a seguir:

Acesso ao Capital: Diversos fundos de investimentos têm sido criados baseados em critérios de responsabilidade social, os chamados SRI (BM\&FBOVESPA, 2012). A demanda por esses fundos cresceu exponencialmente nos últimos anos, possibilitando que empresas consideradas responsáveis tenham acesso mais rápido e barato ao crédito (MARCONDES; BACARJI, 2010). O valor dos ativos de SRI, no Brasil, cresceu 55,34\% de 2006 a 2012 e, nos Estados Unidos, esse valor aumentou 380\% de 1995 a 2010 (BM\&FBOVESPA, 2012).

Aprendizagem e Inovação: A RSC pode gerar criatividade e inovação. A abertura da empresa para relações que vão além dos negócios possibilita novas percepções sobre atividades, processos e desenvolvimento de novos produtos (MOLTENI, 2006; HART; DOWELL, 2011). Muitas organizações atuam com parceiros de negócios para identificar novas abordagens que proporcionam benefícios para o negócio ao mesmo tempo combatem um problema social ou ambiental (PORTER; KRAMER, 2006).

Eficiência Operacional: Significa exercer atividades semelhantes melhor do que os rivais, incluindo todo o tipo de práticas que permitem a empresa utilizar, da melhor forma, os seus recursos (PORTER, 1996). Atividades de RSC podem, por exemplo, reduzir desperdícios e reciclar materiais descartáveis, gerando redução de custos para as empresas e diminuindo a poluição do meio ambiente. Os custos gerados pelos sistemas de proteção ambiental podem ser menores que os custos do uso inadequado dos recursos (HART, 1995; PORTER; LINDE, 1995). Empresas bem conduzidas e lucrativas podem ganhar vantagem de custo por meio da utilização de estratégias ambientais, pois aproveitam de forma mais eficiente os seus recursos e ativos (CHRISTMANN, 2000).

Gerenciamento do Perfil de Risco: A percepção do risco das empresas tem sido ampliada e passou a compreender riscos de longo prazo relativos a questões sociais e ambientais. As demandas dos stakeholders podem ser uma potencial ameaça à viabilidade das atividades da organização. A forma como as empresas respondem a essas demandas pode evitar, por exemplo, boicotes de consumidores, ações judiciais de responsabilidade e aumento de passivo 
trabalhista (KURUCZ et al., 2008). Uma pesquisa, conduzida pela Taylor Nelson Soffres com 302 analistas financeiros e gerentes de fundos na Europa, encontrou que $86 \%$ desses acreditam que o gerenciamento do risco social e ambiental terá um impacto positivo significativo no valor de mercado da empresa no longo prazo (ARTHUR D. LITTLE, 2003).

Licença para Operar: Manter uma política eficiente de RSC proporciona às empresas uma melhor relação com seus stakeholders e com a opinião pública em geral. Empresas com problemas nessa área podem ser alvos constantes de críticas e passam a ter a forma de atuação em relação a diversos assuntos sociais e ambientais questionada por consumidores, ONGs e ativistas (KURUCZ et al., 2008).

Pioneirismo: Está relacionado com a crença de que as empresas que atuam além de suas obrigações legais em relação a questões de responsabilidade social e ambiental se beneficiarão no longo prazo, pois ocuparão posição privilegiada em um cenário em que as atividades estarão mais regulamentadas. (MADARIAGA; CREMADES, 2010)

Reputação: Faz parte dos ativos intangíveis da empresa e é construída e mantida pela capacidade da empresa em atender as expectativas dos múltiplos stakeholders (FOMBRUN et al., 2000). De acordo com um relatório realizado pela empresa de consultoria Arthur D. Little (2003), a proporção do valor da empresa derivada de ativos intangíveis cresceu de $17 \%$ em 1981 para $71 \%$ em 1998. De acordo com esse relatório, estima-se que $96 \%$ do valor da CocaCola abrangem ativos intangíveis de reputação, conhecimento e marca. Para a Kellog's, os ativos intangíveis representam 97\% de seu valor e para a American Express 84\%. Além disso, estudos empíricos, como o de Zyglidopolous (2001) demonstraram que existe uma relação positiva entre reputação e Desempenho Financeiro. A reputação pode ser criada ou destruída como consequência da decisão em se engajar ou não em atividades e divulgação de RSC (FOMBRUN et al., 2000; BRANCO; RODRIGUES, 2006; McWILLIAMS et al., 2006; HUSTED; ALLEN, 2001).

Recrutamento, Motivação e Retenção de Funcionários: A reputação da empresa, como sendo responsável, afeta sua imagem como boa empregadora. A organização que conta com uma política de RSC bem ajustada tem maiores chances de ter bom clima organizacional e de recrutar e reter os melhores talentos (BRANCO; RODRIGUES, 2006; FOMBRUN et al., 
2000). Estudos como de Backhaus et al. (2002) exploraram a relação entre Desempenho Social e atratividade de funcionários e chegaram à conclusão de que pessoas que procuram emprego consideram fatores como meio ambiente, relação com a comunidade, relação com trabalhadores, diversidade e questões relativas a produtos para escolherem onde trabalhar.

\subsection{Diretrizes Teóricas da Pesquisa}

A partir da fundamentação teórica apresentada nos capítulos anteriores, elaborou-se o Quadro 7, que mostra as dimensões analisadas no presente estudo e as questões que serão investigadas na pesquisa de campo, a fim de atingir os objetivos e responder o problema da pesquisa.

Quadro 7 - Diretrizes teóricas da pesquisa.

\begin{tabular}{|c|c|c|}
\hline Dimensão & Questões investigativas & $\begin{array}{c}\text { Fundamentação Teórica } \\
\text { (Autores) }\end{array}$ \\
\hline $\begin{array}{l}\text { Responsabilidade Social } \\
\text { Corporativa (RSC) }\end{array}$ & $\begin{array}{l}\text { - } \quad \text { Definição de RSC; } \\
\text { - } \quad \text { Questões que envolvem RSC; } \\
\text { - } \quad \text { úblicos aos quais a RSC se dirige. }\end{array}$ & $\begin{array}{c}\text { Carroll }(1979,1991,1999, \\
\text { 2008); DeBakker et al. (2005); } \\
\text { Lockett et al. (2006); Crane } \text { et al. } \\
\text { (2008) }\end{array}$ \\
\hline $\begin{array}{l}\text { Desempenho Social } \\
\text { Corporativo }\end{array}$ & $\begin{array}{l}\text { - Forma como a organização responde } \\
\text { às questões de RSC; } \\
\text { - Atividades e processos realizados; } \\
\text { - } \quad \text { Informações utilizadas para a escolha } \\
\text { das atividades e processos; } \\
\text { - Envolvimento das áreas funcionais. }\end{array}$ & $\begin{array}{l}\text { Wood (1991); Clarkson (1995); } \\
\text { Nascimento et al. (2008); } \\
\text { Surroca et al. (2010) }\end{array}$ \\
\hline $\begin{array}{l}\text { Alinhamento entre RSC e } \\
\text { Estratégia Organizacional }\end{array}$ & $\begin{array}{l}\text { - Inserção da variável sociambiental no } \\
\text { processo formal de formulação } \\
\text { estratégica; } \\
\text { - Vínculo das práticas socioambientais } \\
\text { com a atividade principal da empresa; } \\
\text { - } \quad \text { Disseminação da RSC na organização; } \\
\text { - Forma de avaliação dos resultados - } \\
\text { utilização de modelo ou sistema de } \\
\text { indicadores para avaliação do } \\
\text { desempenho social; } \\
\text { - Nível organizacional ao qual os } \\
\text { resultados são reportados. }\end{array}$ & $\begin{array}{c}\text { Hart (1995, 1997); Burke e } \\
\text { Logsdon (1996); Fombrun } \text { et al. } \\
\text { (2000); Husted (2000); } \\
\text { McWilliams e Siegel (2000); } \\
\text { Husted e Allen (2001); Porter e } \\
\text { Kramer (2002, 2006); Husted e } \\
\text { Salazar, (2006); Molteini (2006); } \\
\text { McWilliams et al. (2006, 2011); } \\
\text { Nascimento } \text { et al. (2008) }\end{array}$ \\
\hline
\end{tabular}

\subsection{Caracterização do Setor}

A empresa selecionada para realização da pesquisa de campo pertence ao setor bancário. Dessa forma, foi realizada, também, uma revisão sobre: o setor bancário no Brasil; a RSC no setor bancário; a RSC nos bancos brasileiros; acordos e iniciativas voluntárias; 
regulamentação e desafios da RSC no setor.

\subsubsection{O Setor Bancário no Brasil}

O Quadro 8 mostra um resumo, em ordem cronológica, da história do Sistema Financeiro Nacional (SFN).

\section{Quadro 8 - História do SFN}

1808: vinda da Família Real portuguesa ao Brasil e criação do Banco do Brasil. Posteriormente, foram criadas novas instituições públicas, incluindo Caixas Econômicas.

1836: surgimento do primeiro banco comercial privado brasileiro, o Banco do Ceará, que fechou em 1839.

1863: nascimento dos primeiros bancos estrangeiros no país, o London \& Brazilian Bank e o The Brazilian and Portuguese Bank.

1920: criação da Inspetoria Geral dos Bancos.

1921: fundação da Câmara de Compensação do Rio de Janeiro.

1932: inauguração da Câmara de Compensação de São Paulo.

1945: criação da Superintendência da Moeda e do Crédito (SUMOC).

1946: aparecimento da primeira sociedade de crédito, financiamento e investimento (financeira).

1952: criação do banco de fomento que viria a se tornar, em 1971, o Banco Nacional de Desenvolvimento Econômico e Social (BNDES) e do Banco do Nordeste do Brasil (BNB).

1964: fundação do Banco Central do Brasil (BCB), que substituiu a SUMOC, do Conselho Monetário Nacional (CMN), do Sistema Financeiro de Habitação (SFH) e do Banco Nacional da Habitação (BNH).

1969: surgimento do Sistema Integrado Regional de Compensação (SIRC), permitindo a integração de praças localizadas na mesma região.

1970: criação da Caixa Econômica Federal.

1976: fundação da Comissão de Valores Mobiliários (CVM).

1983: implementação da Compensação Nacional, interligando todo o país.

1988: todo o processo de compensação passa a ser gerido de forma eletrônica.

1996: criação do Comitê de Política Monetária (COPOM) que tem como objetivo estabelecer diretrizes da política monetária, definir a meta da taxa de juros referencial do país (SELIC), bem como compilar relatórios de inflação.

1997: criados o Sistema de Financiamento Imobiliário (SFI) e a Central de Risco de Crédito, gerida pelo BCB.

1999: o CMN institui nove níveis de risco para indicar a qualidade das operações de crédito.

2002: colocados em operação o novo Sistema de Pagamentos Brasileiro (SPB), o Sistema de Transferência de

Reservas (STR), e a Transferência Eletrônica Disponível (TED).

2003: criação das contas-corrente e contas-poupança simplificadas para promover a inclusão financeira.

2006: criação da conta-salário, similar às contas simplificadas, apenas para o recebimento de salários, proventos e pensões e isenta de taxas.

2012: publicação do Edital de Audiência Pública 41/2012 para tornar obrigatória a implementação de uma política de responsabilidade socioambiental por todas as instituições financeiras.

FONTE: BANKTRACK; AMIGOS DA TERRA, 2012, p. 5.

Desde a criação da primeira instituição financeira no país, o Banco do Brasil, em 1808, a economia brasileira passou por diversas mudanças, que foram acompanhadas por transformações no SFN. Em especial, as duas últimas décadas, foram de intensas mudanças. Nesse período, o país conviveu com uma hiperinflação persistente, que só se encerrou com a implementação do Plano Real. Outro evento que ocorreu nesse período, e que foi de grande importância para o setor bancário nacional, foi a entrada de bancos estrangeiros a partir de 
1997. (BANKTRACK; AMIGOS DA TERRA, 2012)

Houve também um aumento do grau de concentração do setor, gerado por fusões e aquisições, e uma redução da importância dos bancos públicos, tanto em número de entidades, quanto em participação no mercado. Em 1997, o país possuía 217 bancos operando, entre públicos e privados nacionais e estrangeiros. Esse número já era 165 em dezembro de 2003 e, no mesmo mês, em 2010, já não ultrapassava 157. Durante o mesmo período, o número de bancos com controle estrangeiro mais que dobrou, enquanto os bancos públicos se reduziram em dois terços. O Quadro 9 mostra o número de bancos públicos e privados existentes no país de 1997 a 2011. (BANKTRACK; AMIGOS DA TERRA, 2012)

\begin{tabular}{|c|c|c|c|c|c|c|c|c|c|c|c|}
\hline Bancos & 1997 & 2002 & 2003 & 2004 & 2005 & 2006 & 2007 & 2008 & 2009 & 2010 & 2011 \\
\hline Públicos & 27 & 15 & 15 & 14 & 14 & 13 & 13 & 12 & 10 & 9 & 9 \\
\hline $\begin{array}{l}\text { Privados } \\
\text { Nacionais }\end{array}$ & 141 & 87 & 88 & 92 & 90 & 90 & 87 & 85 & 88 & 88 & 89 \\
\hline $\begin{array}{c}\text { Privados } \\
\text { Estrangeiros }\end{array}$ & 49 & 65 & 62 & 58 & 57 & 56 & 56 & 62 & 60 & 60 & 62 \\
\hline Total & 217 & 167 & 165 & 164 & 161 & 159 & 156 & 159 & 158 & 157 & 160 \\
\hline
\end{tabular}

FONTE: BCB, 2012.

Apesar das expectativas otimistas, o processo de consolidação bancária no Brasil, com a redução da presença do Estado e a entrada de bancos estrangeiros no setor, mostrou resultados abaixo do esperado sobre a relação crédito/PIB e o custo da intermediação financeira. Houve uma forte queda do spread bancário do patamar de $120 \%$ a.a., em 1994, para estáveis $40 \%$ no início dos anos 2000. A relação crédito/PIB caiu de 35\%, em 1994, para 22\%, em 2002. (CORREA et al., 2010)

A partir de 2003, contudo, verifica-se uma notável mudança no desempenho e na estrutura do setor bancário brasileiro. Com relação ao desempenho, a relação crédito/PIB, que vinha apresentando uma notável redução até 2002, começa a aumentar, alcançando $45 \%$ em meados de 2009, valor que se manteve até janeiro de 2011. No mesmo mês do ano seguinte, o percentual já superava 48,8\%. Com relação à estrutura do setor, o processo de redução da participação do Estado é revertido, com o aumento da presença dos bancos públicos no total de crédito concedido. Entre janeiro de 2003 e fevereiro de 2010, as operações totais de crédito do sistema financeiro público subiram $415 \%$ e do sistema financeiro privado, $348 \%$. (CORREA et al., 2010) 
O SFN é predominantemente bancário, uma vez que esse setor reúne mais de $90 \%$ do total de ativos do sitema. O setor é também altamente concentrado, sendo os seis maiores bancos responsáveis por mais de $75 \%$ dos ativos totais do sistema. Esta concentração é fruto do processo de consolidação iniciado nos anos 1990, tendo se estabilizado nos últimos anos após as duas últimas grandes operações: a compra do Banco Real pelo Santander, em 2007, e a fusão do Itaú com o Unibanco, em 2008. Desde então, apenas operações menores de compra têm ocorrido, aumentando de forma menos significativa a concentração. (BANKTRACK; AMIGOS DA TERRA, 2012). O Gráfico 3 mostra a participação dos dez maiores bancos atuantes no Brasil.

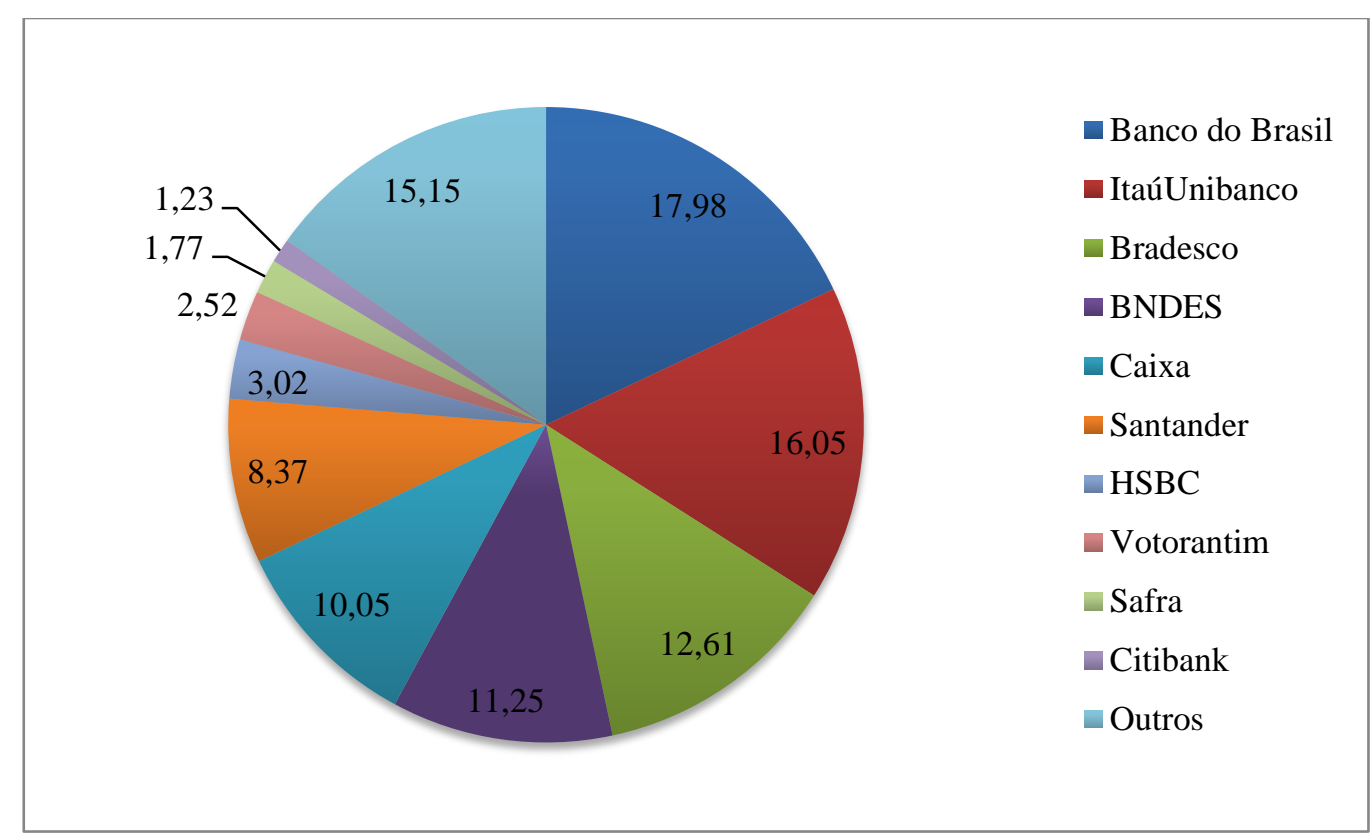

Gráfico 3: Participação dos dez maiores bancos atuantes no Brasil em 2011 (em ativos totais). FONTE: BCB, 2012.

Os seis maiores bancos, com exceção do Banco Nacional de Desenvolvimento Econômico e Social (BNDES), caracterizam-se por manter grandes operações de varejo, voltados tanto para pessoas físicas quanto para pessoas jurídicas, o que os obriga a possuir uma extensa rede de agências. A elevação da renda da população contribuiu para sua bancarização e tem provocado uma corrida entre os principais bancos para a abertura de novas agências, tanto nas capitais quanto em cidades do interior. (BANKTRACK; AMIGOS DA TERRA, 2012)

Além da expansão das redes de agências, os últimos dez anos se caracterizaram por um movimento de segmentação dos clientes, com a criação de estruturas dedicadas ao atendimento de acordo com o retorno potencial de cada segmento. Foram criados segmentos 
premium para os clientes pessoa física, inclusive com agências exclusivas ou áreas exclusivas dentro das agências convencionais. De maneira semelhante, os clientes pessoa jurídica de pequeno e médio porte foram migrados para plataformas de atendimento fora das agências, que mantiveram, em sua maioria, atendimento apenas a microempresas. (BANKTRACK; AMIGOS DA TERRA, 2012)

Outro movimento recente e que tem causado mudanças significativas no mercado é a entrada dos grandes bancos em produtos ou segmentos antes dominados por bancos pequenos e médios especializados, como crédito consignado para pessoas físicas, e capital de giro e desconto de recebíveis para pequenas e médias empresas. $\mathrm{O}$ fenômeno tem forçado os bancos menores a assumir cada vez mais risco e aprofundar suas estratégias de nicho. (BANKTRACK; AMIGOS DA TERRA, 2012)

\subsubsection{RSC no Setor Bancário}

Tradicionalmente, os impactos sociais e ambientais das empresas de serviços não são considerados tão relevantes quanto os impactos dos setores produtivos. Contudo, o amadurecimento do processo de incorporação de indicadores sociais e ambientais aos negócios, em todo o mundo, demonstrou que, por sua importância na economia, o setor de serviços, em especial o financeiro, que tem contato com todos os outros setores produtivos, tem um enorme potencial para influenciar mudanças na sociedade. Além disso, por meio das carteiras dos seus clientes, os bancos estão expostos a um conjunto de questões sociais e ambientais mais diversificado do que a média de negócios.

As instituições financeiras, como provedoras de financiamento para empresas de todos os tipos e tamanhos, têm um papel crucial na promoção da responsabilidade socioambiental em todas as indústrias, setores e comunidades. As práticas de responsabilidade socioambiental também oferecem grande potencial para as instituições financeiras melhorarem os seus próprios produtos e serviços. Essa abordagem é uma propulsora de melhorias, tanto internas quanto na maneira de se relacionar com os clientes. Olhar as questões sociais e ambientais nas práticas bancárias favorece a gestão de riscos, em especial, relacionados à exposição negativa de imagem (IFC, 2007). 
A pesquisa Sustainability Survey of Financial Institutions, realizada pela Internacional Finance Corporation (IFC), em 2005, com 120 bancos de 43 mercados emergentes, revelou que a principal razão que leva os bancos a considerarem aspectos sociais e ambientais em suas práticas de gestão é o aumento de credibilidade e reputação, conforme Gráfico 4. Os benefícios que os respondentes acreditam que a gestão da sustentabilidade traz para os bancos são mostrados no Gráfico 5.

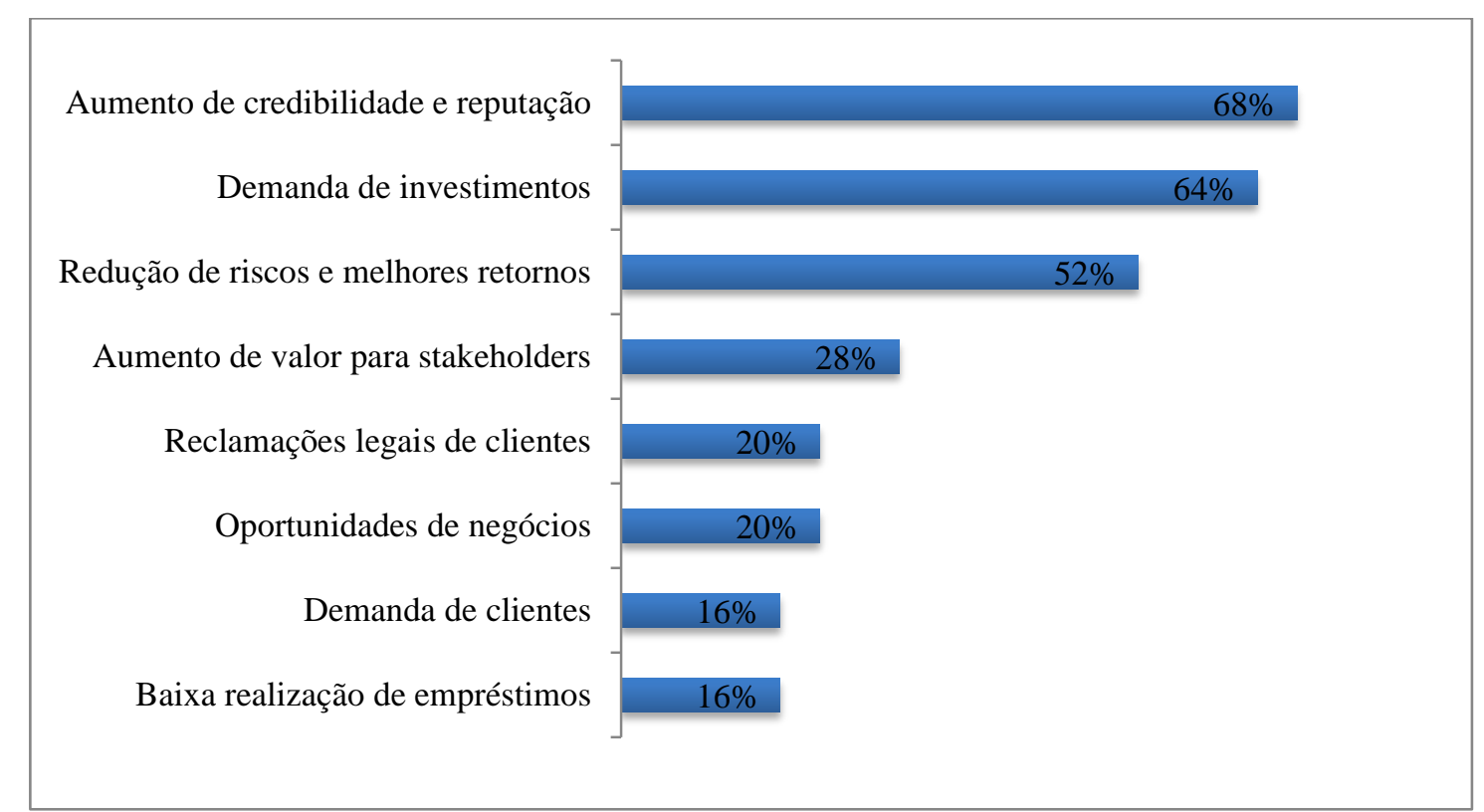

Gráfico 4 - Motivações para bancos incorporarem a sustentabilidade (porcentagem de respondentes). FONTE: Adaptado de IFC, 2007.

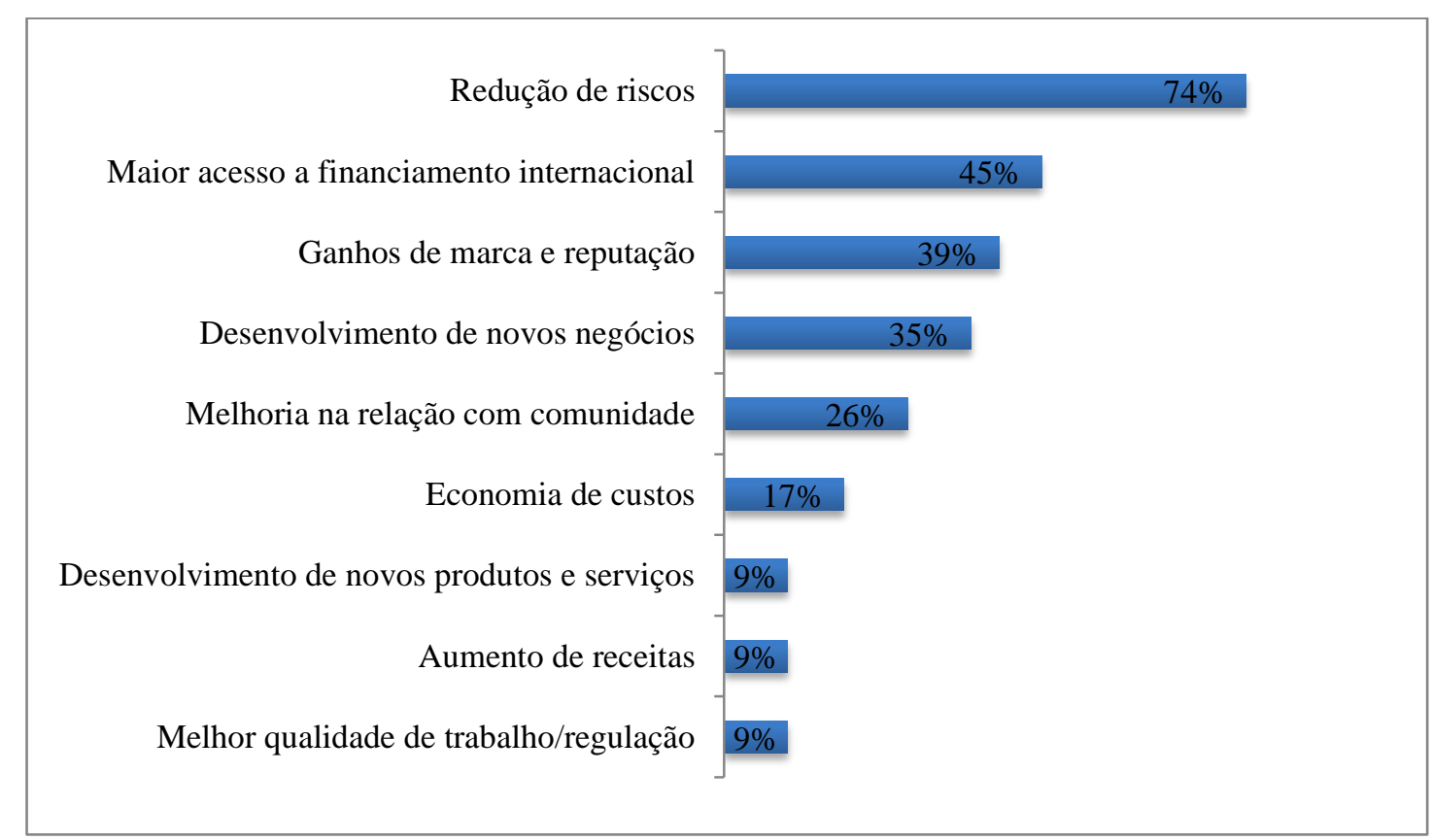

Gráfico 5 - Benefícios da incorporação da sustentabilidade (porcentagem de respondentes). FONTE: Adaptado de IFC, 2007. 
Os bancos e outras instituições financeiras estão, cada vez mais, se deslocando da postura de evitar riscos para a postura de criar oportunidades, ou seja, saindo da postura defensiva- em que a questão social e ambiental é vista como um custo adicional- para a postura sustentável em que o desenvolvimento sustentável é visto como uma vantagem e uma oportunidade de crescimento (IFC, 2007).

Portanto, para as instituições financeiras, a responsabilidade socioambiental tem dois componentes. Um componente é a gestão dos riscos sociais e ambientais na tomada de decisões estratégicas e na concessão de empréstimos. Elas podem concentrar investimentos em empresas e projetos com maior desempenho ambiental, social e financeiro, o que ajuda a proteger a sua carteira de ativos, diminuindo empréstimos inadimplentes, aumentando a estabilidade financeira e protegendo sua reputação. O outro componente é a identificação de oportunidades para o desenvolvimento de novos produtos em áreas relacionadas com a responsabilidade socioambiental. Por exemplo, oportunidades ligadas à energia renovável, eficiência energética, processos e tecnologias de produção mais limpas, conservação da biodiversidade, microfinanças e serviços financeiros voltados para habitação de baixa renda.

\subsubsection{RSC nos Bancos Brasileiros}

Os esforços dos bancos brasileiros voltados para a responsabilidade socioambiental começaram com relatórios sociais no início de 1990, quando o Banco do Estado de São Paulo (BANESPA) publicou o primeiro relatório social do SFN. Em 1993, a Federação Brasileira de Bancos (FEBRABAN) emitiu o primeiro relatório social para a indústria financeira. E, desde 2004, cinco dos maiores bancos no Brasil têm disponibilizado informações não financeiras para o público, seja por meio de relatório social separado ou em seus relatórios anuais.

Em 2001, o então banco líder de renome mundial em sustentabilidade, o Banco Real, começou a incorporar formalmente avaliações de aspectos sociais e ambientais das operações em seu processo de aprovação de financiamento. Em 2000, o Banco BBA Creditanstalt (hoje Banco Itaú-BBA) tornou-se o primeiro banco a estabelecer um conjunto de procedimentos formais para gerenciar os riscos sociais e ambientais, e exigir a consideração explícita das questões ambientais em financiamentos de projetos. Em 2002, o Unibanco lançou o seu próprio sistema de gerenciamento de risco social e ambiental. 
Em pesquisa realizada pelo Banco Central do Brasil (BCB) e o Uniethos, em 2011, com 210 instituições financeiras brasileiras, encontrou-se que, na maioria dos grandes bancos e dos bancos de desenvolvimento, a Sustentabilidade vem sendo incorporada em suas políticas e processos. Contudo, apenas $12 \%$ dos bancos médios e pequenos e $35 \%$ dos bancos de investimento possuem políticas formais. Nas cooperativas de crédito e nas agências de fomento, o tema está em processo de desenvolvimento e essas instituições ainda não possuem políticas formais de Sustentabilidade. A divulgação de informações sobre essas políticas também é, ainda, restrita a um pequeno número de instituições. Apenas 22 do total de 210 instituições possuem relatórios de Sustentabilidade (BCB; UNIETHOS, 2011). O Quadro 10 mostra os dados da pesquisa mencionada.

\section{Quadro 10 - Sustentabilidade nas instituições financeiras atuantes no Brasil.}

\begin{tabular}{|c|c|c|c|}
\hline Tipo de Instituição & $\begin{array}{c}\text { Número Total de } \\
\text { Instituições }\end{array}$ & $\begin{array}{c}\text { Instituições com } \\
\text { Políticas de } \\
\text { Sustentabilidade }\end{array}$ & $\begin{array}{c}\text { Instituições com } \\
\text { Relatórios de } \\
\text { Sustentabilidade }\end{array}$ \\
\hline Bancos Grandes & 10 & 8 & 8 \\
\hline Bancos Médios e Pequenos & 128 & 16 & 9 \\
\hline Bancos de Desenvolvimento & 4 & 3 & 2 \\
\hline Bancos de Investimento & 14 & 5 & 3 \\
\hline Agências de Fomento & 16 & 0 & 0 \\
\hline Centrais de Cooperativas de Crédito & 38 & 0 & 22 \\
\hline Total & 210 & 32 & 0 \\
\hline
\end{tabular}

FONTE: BCB; UNIETHOS, 2011, p. 5.

No SFN, oito dos dez maiores bancos possuem tanto uma política de sustentabilidade, quanto um relatório anual de desempenho nas questões socioambientais e de governança corporativa. Esse número cai drasticamente, quando analisadas as instituições do mesmo tipo de pequeno e médio porte. Apenas 12,5\% do total possuem políticas focadas no tema e 7\% divulgam algum tipo de relatório. Entre os bancos de investimento, apenas 35\% possuem uma política específica para o tema e um pouco mais de $20 \%$ emitem relatórios. Nas agências de fomento e cooperativas de crédito, o tema não é considerado em suas políticas de negócios, já que nenhuma dessas possui diretrizes para o assunto. Entre os bancos de desenvolvimento, apenas um (BRDE) não possui uma política específica para sustentabilidade e metade deles divulga relatório. No geral, somente $15 \%$ do total de instituições financeiras do SFN possuem políticas em sustentabilidade e 10\% geram relatórios. (BCB; UNIETHOS, 2011)

A pesquisa também analisou ações mais específicas, como gestão de riscos socioambientais, produtos financeiros para sustentabilidade, governança corporativa, programas de educação, 
relacionamento com clientes e políticas relacionadas ao clima. A conclusão dessa análise é que apenas $8 \%$ das instituições financeiras no Brasil possuem políticas bem estruturadas de sustentabilidade.

Portanto, as instituições do SFN podem ser classificadas em três grupos. Um pequeno grupo de bancos líderes adota a sustentabilidade com abordagem estratégica que fortalece a capacidade competitiva. Outro grupo de instituições está em uma fase intermediária de incorporação da sustentabilidade, com abordagem gerencial e foco prioritário na gestão do risco. Finalmente, a maioria das instituições está em uma fase inicial, na qual existe a consciência da importância da sustentabilidade, mas ainda não há formulação e implementação de políticas e processos de gestão sustentáveis. (BCB; UNIETHOS, 2011)

Apesar desses dados, o Brasil foi um dos primeiros países a desenvolver um conjunto de princípios de sustentabilidade para as instituições que operam no país, o Protocolo Verde, e é um dos países com maior número de instituições signatárias de padrões internacionais. Grandes bancos brasileiros são referências reconhecidas internacionalmente. Por exemplo, o Itaú Unibanco faz parte do DJSI desde 1999, e o Bradesco desde 2006.

Alguns bancos brasileiros também foram reconhecidos internacionalmente em premiações e relatórios importantes relativos ao tema. O Banco $A B N A M R O$ Real ganhou o prêmio Sustainable Finance Awards, concedido pelo jornal britânico Financial Times e pelo IFC, de banco mais sustentável de países emergentes, em 2006. O prêmio foi criado como forma de reconhecer os bancos que demonstram liderança e inovação na aplicação de critérios sociais, ambientais e de governança corporativa em suas operações. Além disso, o ABN AMRO Real foi um estudo de caso da Harvard Business School pela aplicação de critérios de nível internacional na integração de aspectos sociais e ambientais por toda a instituição. O Banco do Brasil ganhou o prêmio em 2007, na categoria de países latino-americanos. Além disso, os bancos Itaú BBA e Unibanco já foram citados como exemplos de atuação responsável em relatórios do IFC sobre sustentabilidade bancária em países emergentes. Em 2011, o Itaú Unibanco foi eleito o banco mais sustentável do mundo pelo mesmo prêmio. 


\subsubsection{Acordos e Iniciativas Voluntárias}

A primeira iniciativa global para promover a integração de recomendações sobre aspectos socioambientais em operações e serviços do setor financeiro foi a criação do Programa das Nações Unidas para o Meio Ambiente em Instituições Financeiras (UNEP-FI), em 1992, lançada durante a Rio 92. Os seus princípios e compromissos foram divulgados no mesmo ano, quando a iniciativa e mais cinco bancos - NatWest Bank, Deutsche Bank, Royal Bank of Canada, Hong Kong \& Shanghai Banking Corporation e Westpac Banking Corporationprepararam um termo de compromisso, a Declaração Internacional dos Bancos para o Meio Ambiente e Desenvolvimento Sustentável. O documento estabelece o compromisso das instituições financeiras com o desenvolvimento sustentável e com a regulação ambiental em nível local, nacional e internacional. A iniciativa apoia a avaliação e gestão de riscos ambientais, recomenda a publicação de políticas ambientais e sua aplicação nas operações financeiras e o diálogo aberto com stakeholders sobre questões ambientais. Até o final de 1992, 23 bancos comerciais já haviam assinado a declaração. Em dezembro de 2004, 163 instituições financeiras de todo o mundo já eram signatárias da Declaração do UNEP-FI. No Brasil, em 2008, os bancos membros da iniciativa eram Itaú, Santander e HSBC.

Outro exemplo de acordo voluntário no setor financeiro refere-se aos Princípios do Equador, lançados em junho de 2003, por dez bancos - ABN Amro, Barclays, Citigroup, Credit Lyonnais, Credit Suisse, HypoVereinsbank, Rabobank, Royal Bank of Scotland, WestLB e Westpac - estabelecem diretrizes socioambientais para financiamentos acima de US\$50 milhões. Naquele ano, esses bancos juntos financiavam, em média 30\%, do total de operações de project finance em todo o mundo. Atualmente, 79 instituições bancárias adotam os Princípios. Em junho de 2004, o Unibanco foi o primeiro banco brasileiro e de mercados emergentes a aderir à iniciativa. Em seguida, os bancos Itaú, Bradesco, Banco do Brasil e Caixa Econômica Federal se tornaram signatários. Em julho de 2006, os Princípios foram revistos considerando-se a experiência das instituições financeiras que já os praticavam, seus clientes e representantes da sociedade civil. Entre as mudanças resultantes desse processo de revisão, destaca-se a redução do custo total do projeto de US\$ 50 milhões para US\$10 milhões. Além disso, os Princípios passaram a valer também para atividades de consultoria financeira de projetos nos quais os impactos sociais ou ambientais sejam significativos. 
Alguns exemplos de quesitos avaliados são: proteção dos direitos humanos e da saúde pública e segurança da comunidade; proteção do patrimônio cultural e arqueológico; aquisição de terras e reassentamento involuntário; impactos em povos indígenas e em sua cultura, suas tradições e seus valores; prevenção da poluição e minimização de resíduos, controles de poluição e gestão de resíduos sólidos e químicos.

Diversas outras iniciativas voluntárias relacionadas ao setor bancário têm surgido ao longo da década de 2000 e continuam a aumentar em quantidade e em grau de compromisso que os signatários devem cumprir. Além das duas já citadas, destacam-se os Principles for Responsible Investment (PRI), que visa a estabelecer critérios sociais, ambientais e de governança corporativa na tomada de decisão de investimentos. O PRI surgiu em 2006 e é adotado por 203 gestores de ativos (fundos de pensão, seguradoras, fundações, trust funds, etc.), 390 gestores de investimentos e 137 empresas de serviços da área de investimentos, incluindo Bolsas de Valores.

No Brasil, a FEBRABAN e Ministério do Meio Ambiente assinaram, em 2009, o Protocolo Verde, que estabelece que os bancos signatários se comprometam a desenvolver critérios socioambientais para seus financiamentos e a promover linhas de crédito diferenciadas para projetos com "adicionalidade" socioambiental.

Foram criados também padrões de mensuração, divulgação e redução de emissões de gases de efeito estufa (GEE). Os mais adotados pelos bancos são o Carbon Disclosure Project (CDP), o Carbon Principles e o Climate Principles. O CDP foi lançado em 2000 e oferece diretrizes para as empresas publicarem relatórios anuais de emissões, estratégias para reduzi-las, e oportunidades e riscos relacionados às mudanças climáticas. Recentemente, o CDP tem tentado mobilizar as empresas a divulgarem suas emissões e atividades nos demais elos da cadeia produtiva, reforçando a visão de corresponsabilidade pelas emissões. O Carbon Principles foi criado em 2007 por seis bancos - Bank of America, Citi, Credit Suisse, JPMorgan Chase, Morgan Stanley e Wells Fargo - para avaliar os riscos de financiamentos relacionados a emissões de GEE em empresas do setor de energia elétrica. Finalmente, o Climate Principles foi lançado em 2008 e as organizações que adotam os princípios se comprometem a considerar as mudanças climáticas em seus produtos e serviços financeiros, como atividades de pesquisas, gestão de ativos, seguros e financimaneto de projetos. 


\subsubsection{Regulamentação da RSC}

Mais recentemente, alguns órgãos como o $\mathrm{BCB}$ vêm criando mecanismos para incluir a responsabilidade socioambiental no SFN. Em 2008, o BCB, por meio de uma resolução, determinou que os bancos públicos e privados que fornecem crédito rural devem exigir dos tomadores de crédito documentação comprobatória de regularidade ambiental para financiamentos agropecuários na região amazônica.

Em meados de 2010, a Diretoria Colegiada do BCB criou uma área no Departamento de Análise de Atos Normativos (DENOR) para tratar dos assuntos relacionados à responsabilidade socioambiental do SFN e da inclusão financeira da população, por entender que é seu papel assegurar um sistema financeiro que contribua para o desenvolvimento sustentável. Em dezembro do mesmo ano, o BCB e o Ministério do Meio Ambiente assinaram o Acordo de Cooperação Técnica com o intuito de desenvolver medidas que permitam acompanhar as ações socioambientais realizadas pelas instituições financeiras signatárias do Protocolo Verde. (BCB; UNIETHOS, 2011)

Ainda em 2010, foi implementado o Projeto Responsabilidade Socioambiental do Sistema Financeiro, que estabelece um padrão de boas práticas para instituições financeiras reguladas pelo BCB (BANKTRACK; AMIGOS DA TERRA, 2012). Com o objetivo de dar consecução prática a esse Acordo de Cooperação Técnica e desenvolver ações que contribuíssem na construção de sistema financeiro sustentável, sob o ponto de vista econômico, social e ambiental, entendeu-se que seria necessário estabelecer um padrão de boas práticas de RSC para as instituições financeiras reguladas pelo BCB. Para isso, foi implementado o Projeto Responsabilidade Socioambiental do Sistema Financeiro, aprovado pelo Comitê de Projetos Corporativos. Uma das primeiras atividades do projeto foi conhecer as práticas socioambientais nos sistemas financeiros nacional e internacional, buscando identificar as melhores práticas adotadas pelas instituições financeiras pesquisadas. (BCB; UNIETHOS, 2011)

Contudo, somente em 2012, o BCB se posicionou como regulamentador do processo de integração da sustentabilidade no SFN, ao publicar o Edital de Audiência Pública 41/2012 para tornar obrigatória a implementação de uma política de responsabilidade socioambiental 
por todas as instituições financeiras e outros órgãos. A medida também prevê que as companhias abertas devem necessariamente publicar um relatório socioambiental.

Em workshop realizado pelo BCB e Uniethos, em 2011, os grandes bancos afirmaram que o BCB deveria atuar mais como orientador do que normatizar. O BCB teria, também, um papel junto ao governo para a criação ou ampliação de bases de dados sobre informações socioambientais das empresas. Além disso, poderia ser um agente de promoção do debate sobre um marco jurídico que defina mais claramente os limites da responsabilização direta e indireta das instituições financeiras sobre impactos sociais e ambientais, gerados por cliente ou projetos financiados. (BCB; UNIETHOS, 2011)

É possível notar, portanto, que apesar de baixa, a regulamentação com relação à responsabilidade socioambiental dos bancos vem aumentando nos últimos anos. As novas medidas têm buscado enfatizar a questão do gerenciamento dos riscos de natureza socioambiental, obrigando os bancos a possuir ferramentas para a mensuração desses riscos em suas atividades e criando um sistema de avaliação com critérios consistentes. Além disso, os bancos deverão estabelecer critérios e mecanismos de mitigação de impactos para os setores com grandes externalidades ambientais, e fazer uma avaliação prévia dos impactos socioambientais de novos produtos e serviços que pretendem incluir em seus portfolios.

\subsubsection{Desafios da RSC no Setor Financeiro}

A pesquisa Sustainability Survey of Financial Institutions, realizada em 2005, apontou que os bancos dos mercados emergentes vêm aumentando sua sensibilidade para questões sociais e ambientais e para a necessidade da gestão eficaz dessas questões. Porém, os bancos pesquisados levantaram algumas barreiras para implementação de sistemas de gestão socioambientais, conforme mostra o Gráfico 6. As barreiras mais significativas relatadas foram a falta de exemplos de boas práticas em instituições financeiras, a falta de conhecimento e capacidades internas e os altos custos de desenvolvimento de sistemas. 
Falta de exemplos de boas práticas de gestão socioambiental em insituições financeiras

Falta de conhecimento/ capacidades internas

Altos custos para desenvolver e implementar diretrizes e processos

Falta de consultores de questões socioambientais para aconselhar clientes

Potenciais inconsistências entre regulações governamentais e exigencias de outras instituições

Não consideram a gestão socioambiental necessária

Falta de consultores de questões socioambientais para aconselhar a empresa

Não é uma prática padrão no setor financeiro

Crença de que não há ganhos para o negócio

Os clientes não fazem essa exigência

Preocupação em como os acionistas enxergarão essa mudança

Outros

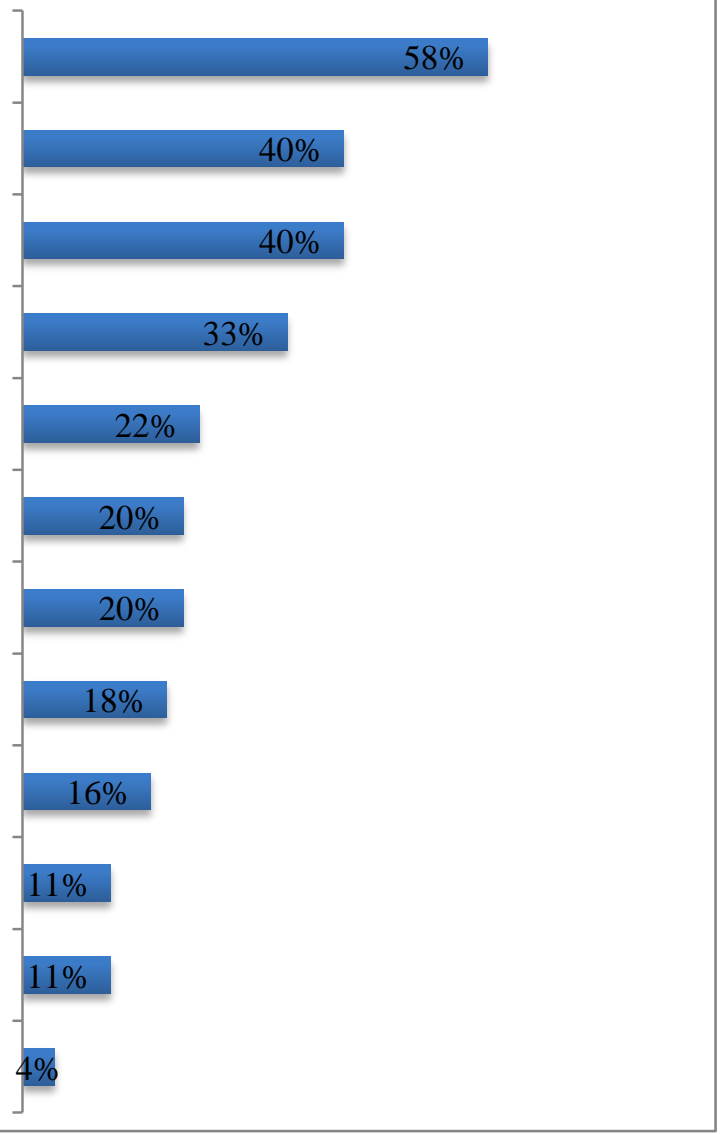

Gráfico 6 - Barreiras para implementar sistemas de gestão socioambiental (porcentagem de bancos comerciais).

FONTE: Adaptado de IFC, 2007.

É importante destacar que a percepção de barreiras diminuiu entre a pesquisa realizada em 2005 e a anterior, realizada pela mesma instituição em 2002. Por exemplo, a porcentagem de entrevistados que afirmaram que a gestão social e ambiental não é uma prática padrão no setor bancário diminuiu de $50 \%$ para $18 \%$. A percepção de que os clientes não querem que seu banco implemente tais procedimentos baixou de $19 \%$ para $11 \%$. E a crença de que não há nenhum ganho para os negócios reduziu de $31 \%$ para 16\%. (IFC, 2007)

Os bancos que implementaram um sistema formal foram os que mais demandaram exemplos de boas práticas. Isso pode ser um indicativo de que os bancos percebem que precisam de mais ajuda prática e orientação conforme o processo de implementação vai ocorrendo. A grande maioria dos bancos comerciais que participaram da pesquisa (86\%) afirmou que gostaria de receber mais assistência em questões de sustentabilidade. Eles destacaram as seguintes demandas: fornecer meios para melhorar o conhecimento sobre sustentabilidade, fornecer informações e promover assistência técnica e serviços de consultoria sobre o tema. (IFC, 2007) 
Em workshop realizado pelo BCB em parceria com a Uniethos, em 2011, o grupo formado pelos grandes bancos brasileiros identificou alguns desafios para o desenvolvimento da sustentabilidade nas instituições financeiras. Um deles é a indefinição jurídica quanto ao limite da responsabilidade dos bancos pelos possíveis impactos sociais ou ambientais em seus financiamentos. A existência de produtos sustentáveis também é considerada um problema para alguns bancos devido a conflitos entre as áreas comerciais e de sustentabilidade, principalmente por não haver estímulos financeiros para a venda desses produtos. Outro problema é rotular alguns produtos como sustentáveis, pois o resto da carteira fica com a imagem de não sustentável, gerando questionamento por parte do cliente. (BCB; UNIETHOS, 2011) 


\section{PROCEDIMENTOS METODOLÓGICOS}

\subsection{Método da Pesquisa}

Conforme identificado na literatura, o campo da RSC é pouco consolidado e abrange uma série de elementos e interrelações complexas, as quais poderão ser mais bem analisadas com um estudo em maior profundidade e que considere o fenômeno na sua totalidade.

A presente pesquisa é exploratória, realizada em área com pouco conhecimento acumulado e sistematizado, com abordagem qualitativa por meio da estratégia de Estudo de Caso. A abordagem qualitativa envolve entrevistas e observações que não resultam em dados quantitativos, mas em descrições dos resultados e das impressões dos eventos. Com essa abordagem, é possível explorar relações que não poderiam ser feitas de outra forma. A maior limitação é a impossibilidade de generalizações dos resultados para populações maiores ou para situações mais gerais. Normalmente, não é possível incluir amostras representativas, devido problemas práticos de escala e à natureza das observações e das situações estudadas. (BLACK, 1999)

O Estudo de Caso é uma pesquisa empírica que investiga um fenômeno contemporâneo dentro de seu contexto real, em que as fronteiras entre o fenômeno e o contexto não são claramente evidentes e no qual múltiplas fontes de evidências são utilizadas. A opção pelo Estudo de Caso surge do desejo de se compreender um fenômeno social complexo e permite preservar as características holísticas e significativas dos eventos da vida real. (YIN, 2010)

Black (1999) afirma que estudos de casos e trabalhos que utilizam amostras representativas se complementam, adicionando uma nova dimensão à evolução da teoria ou resolvendo um problema prático. Os estudos de casos aprimoram a investigação de objetos em situações reais, nas quais as interações são de interesse primordial, e proporcionam maior profundidade no estudo das cadeias de eventos. Pesquisas com amostras representativas possibilitam maior generalização, porém tendem a utilizar um menor número de variáveis e a estar em um contexto que não é o ideal para se relacionar os resultados a situações reais. Estudos de casos permitem que se respondam perguntas do tipo "por que" e "como" de forma mais completa, 
enquanto que aqueles com amostras representativas permitem verificar o quanto um fenômeno pode ser generalizado. (BLACK, 1999)

Na literatura de RSC, encontram-se diversos estudos empíricos quantitativos que comparam o Desempenho Social com o Desempenho Financeiro das empresas, porém com resultados encontrados muito divergentes. Enquanto algumas pesquisas mostraram desempenho superior para empresas consideradas mais responsáveis, outras não acharam diferenças e, ainda, outras encontraram desempenho inferior (McWILLIAMS et al., 2006; CRANE et al., 2008). Alguns desses estudos utilizam indicadores de desempenho social, como o ISE, no Brasil, ou o Kinder, Lydenberg and Domini (KLD), nos Estados Unidos, para caracterizar se a empresa tem ou não Desempenho Social. Nesses trabalhos, outras variáveis que também podem influenciar o Desempenho Financeiro da empresa - além do Desempenho Social - são controladas nos modelos, como: tamanho e risco da empresa; indústria na qual a empresa atua; investimento em pesquisa e desenvolvimento; intensidade de propaganda da indústria. Com a utilização da técnica de regressão linear múltipla, testa-se a correlação entre a variável independente (Desempenho Social) e a variável dependente (Desempenho Financeiro).

Mesmo com o cuidado de se controlar outras variáveis que podem influenciar a variável dependente, é muito difícil provar estatisticamente uma relação causal entre Desempenho Social e Desempenho Financeiro. Muitos fatores endógenos podem levar à adoção de práticas de RSC, por exemplo, relacionados à inovação, recursos humanos, reputação e cultura organizacional. Esses fatores influenciam tanto o Desempenho Social quanto o desempenho da empresa, o que poderia confundir os resultados. Além disso, o próprio Desempenho Financeiro da empresa pode influenciar a adoção de RSC, invertendo-se a direção da relação causal.

Dessa forma, estudos quantitativos podem ser limitados em sua capacidade de explicar "como" ou "por que" a relação existe ou não, enquanto que estudos de caso podem investigar tais aspectos. Devido a esses motivos, optou-se por uma pesquisa exploratória qualitativa em maior profundidade, com a utilização da estratégia do Estudo de Caso. 


\subsection{Seleção do Caso}

Segundo Eisenhardt (1989), em estudos de casos, não são utilizadas amostras estatísticas, mas, sim, amostras teóricas. O caso deve ser escolhido para replicar ou estender uma teoria emergente, como também para completar categorias teóricas. Para a autora, faz sentido que se escolha um caso em que o processo de interesse seja facilmente observável. Assim, o objetivo da amostra teórica é escolher um caso em que a teoria emergente possa ser replicada ou estendida.

O caso escolhido para o presente estudo foi a empresa Itaú Unibanco, por atender aos seguintes critérios:

a) ter participado das oito edições da carteira do ISE, da BM\&FBOVESPA, desde sua criação em 2005. As empresas que compõem a carteira do ISE são selecionadas por meio de procedimentos metodológicos desenvolvidos pelo Centro de Estudos em Sustentabilidade da Fundação Getúlio Vargas (GVces), com financiamento do IFC, órgão de financiamento privado do Banco Mundial. O questionário aplicado é composto por sete dimensões: ambiental, econômico-financeira, geral, governança corporativa, mudanças climáticas, natureza do produto e social (GVCes, 2012);

b) ter participado das 13 edições da carteira do DJSI, desde sua criação em 1999. O DJSI é formado por um conjunto de índices que avaliam o desempenho socioambiental das 2500 maiores empresas listadas no Dow Jones Global Total Stock Market. O Índice se tornou referência em sustentabilidade para investidores e empresas de todo o mundo. $\mathrm{O}$ DJSI é baseado na análise do desempenho econômico, ambiental e social da empresa, avaliando questões como governança corporativa, gestão de risco, mitigação dos efeitos das mudanças climáticas, padrões da cadeia de valor e práticas trabalhistas. A tendência é rejeitar empresas que não operam de forma sustentável e ética. O Índice inclui tanto critérios gerais quanto critérios específicos de cada um dos 58 setores definidos de acordo com a Industry Classification Benchmark (ICB). 
Por atender a esses critérios, considerou-se que a empresa representa um caso onde ocorre ou ocorreu o fenômeno de interesse do estudo e que, portanto, dispõe de elementos para explicálo.

\subsection{Coleta de dados}

Para a coleta de dados serão seguidos três princípios, conforme indicado por YIN (2010):

a) utilizar múltiplas fontes: evidências de duas ou mais fontes, convergindo sobre os mesmos fatos ou descobertas (triangulação de dados);

b) criar uma base de dados: uma estrutura formal de evidência, distinta do relatório final do Estudo de Caso. Pode ser composta por notas, documentos, tabelas e narrativas;

c) manter o encadeamento de evidências: vínculos explícitos entre as questões formuladas, os dados coletados e as conclusões a que se chegou.

A Ilustração 6 mostra como permitir ao leitor do Estudo de Caso seguir a derivação de qualquer evidência das questões de pesquisa iniciais para finalizar as conclusões, podendo traçar os passos em qualquer direção. O processo deve ser rigoroso o suficiente para que a evidência apresentada seja certamente a mesma evidência coletada. Da mesma forma, nenhuma evidência original deve ser perdida, por descuido ou parcialidade, deixando de receber a atenção apropriada na consideração dos "fatos". Se esses objetivos forem atingidos, o Estudo de Caso também terá abordado o problema metodológico de determinação da validade do constructo, aumentando a qualidade total da pesquisa. (YIN, 2010) 


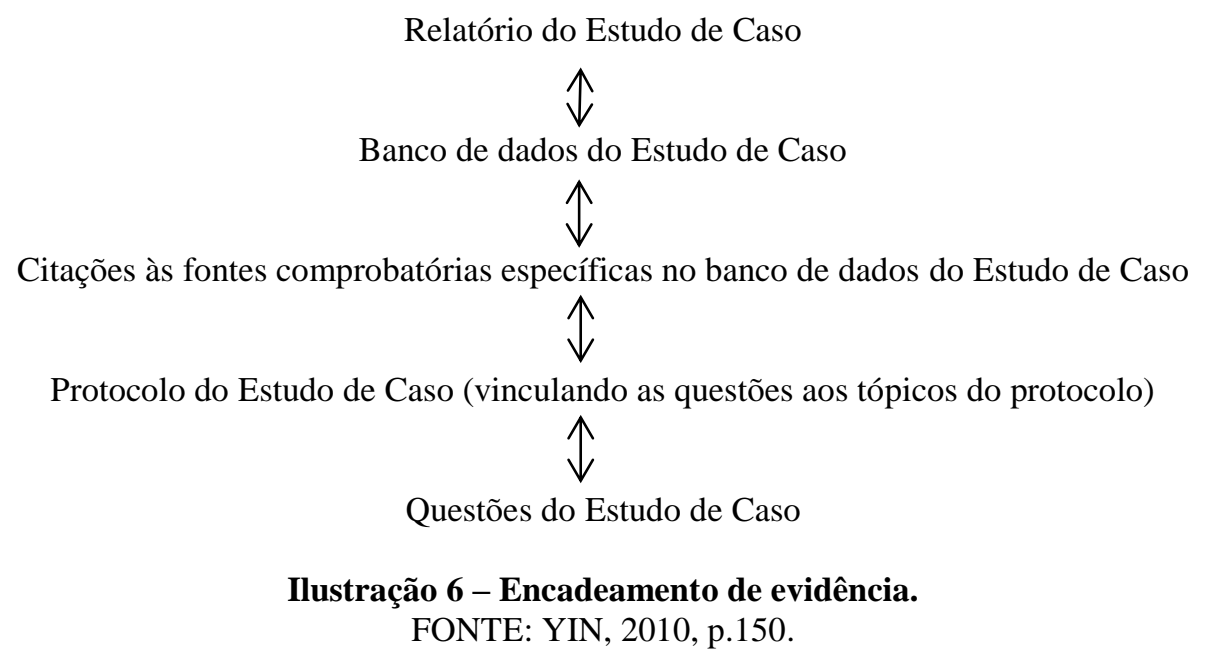

A coleta de dados foi realizada por meio de dados primários, obtidos por entrevistas individuais. Os pontos fortes da entrevista são: a) focam diretamente os tópicos do estudo e b) fornecem inferências e explanações causais percebidas. Já os pontos fracos são: a) possíveis questões mal formuladas, b) parcialidade na resposta e c) incorreção na resposta devido à falta de memória. (YIN, 2010)

As entrevistas realizadas foram semiestruturadas, permitindo ao entrevistador desenvolver cada situação na direção em que considerasse adequada, e baseadas em roteiro prévio, que serviu como guia. Portanto, ao longo da interação, as perguntas e os tópicos eram abordados para que todas as questões de interesse fossem tratadas. As entrevistas foram realizadas pessoalmente na própria empresa. O roteiro das entrevistas encontra-se no Apêndice 1.

Para a seleção dos entrevistados, buscou-se contato com pessoas vinculadas à área de Sustentabilidade da empresa, pois são elas que mais possuem conhecimento sobre o assunto de interesse. Foram entrevistadas a Superintendente de Sustentabilidade e uma Gerente de Sustentabilidade, ou seja, pessoas com alto nível gerencial, que participam dos processos de decisões e que têm acesso a todas as informações relativas ao fenômeno estudado. Além delas, foi entrevistada uma Gerente de Cultura e Clima Organizacional, por entender-se que seria necessário entrevistar uma pessoa fora da área de Sustentabilidade e que pudesse ter informações sobre a disseminação do tema pelas outras áreas da organização. As entrevistadas foram denominadas E1, E2 e E3, de forma a preservar suas identidades. As entrevistas foram realizadas no período de 01/04/2013 a 03/06/2013. O Quadro 11 traz os principais dados das entrevistadas. 
Quadro 11 - Gestoras entrevistadas na pesquisa de campo.

\begin{tabular}{|c|c|c|c|c|}
\hline & Cargo & Área & $\begin{array}{c}\text { Tempo na } \\
\text { Empresa (anos) }\end{array}$ & $\begin{array}{c}\text { Tempo na Área } \\
\text { (anos) }\end{array}$ \\
\hline E1 & Superintendente & Sustentabilidade & 6 & 3 \\
\hline E2 & Gerente & Sustentabilidade & 6 & 6 \\
\hline E3 & Gerente & Cultura e Clima Organizacional & 13 & 5 \\
\hline
\end{tabular}

Segundo Stake (2005), nem todos os aspectos de um caso podem ser compreendidos, por isso a decisão de até onde é necessário investigar é uma escolha do pesquisador. Dessa forma, o número de entrevistas foi escolhido devido ao entendimento de que mais informantes não trariam informações novas relevantes.

Além das entrevistas, foram coletados dados por meio de fontes secundárias. Os pontos fortes das fontes por documentação são: a) podem ser revistas repetidamente; b) não foram criadas em consequência do Estudo de Caso; c) contêm nomes, referências e detalhes exatos; d) abrangem um período de tempo mais amplo. Os pontos fracos são: a) podem ter sofrido uma seletividade; b) podem ser parciais; c) podem ter acesso negado. (YIN, 2010)

As fontes secundárias utilizadas foram relatórios divulgados pela própria empresa: Relatórios Anuais de Sustentabilidade de 2008 a 2012 e outros relatórios disponíveis no website do banco. Além disso, foram coletados dados de documentos e relatórios elaborados por outras instituições: Instituto Ethos, BCB, Federação Brasileira de Desenvolvimento Sustentável (FBDS), IFC, BankTrack e Amigos da Terra. Foram utilizados também artigos publicados na mídia. O Quadro 12 mostra os principais documentos utilizados como fonte de dados secundários.

Quadro 12 - Fontes dos dados secundários.

\begin{tabular}{|c|c|c|}
\hline Documento & Instituição & Ano \\
\hline Relatório Anual de Sustentabilidade & Itaú Unibanco & 2008 \\
\hline Relatório Anual de Sustentabilidade & Itaú Unibanco & 2009 \\
\hline Relatório Anual de Sustentabilidade & Itaú Unibanco & 2010 \\
\hline Relatório Anual de Sustentabilidade & Itaú Unibanco & 2011 \\
\hline Relatório Anual de Sustentabilidade & Itaú Unibanco & 2007 \\
\hline Banking on Sustainability & IFC & 2007 \\
\hline $\begin{array}{c}\text { Sustentabilidade Corporativa no Setor } \\
\text { Financeiro Brasileiro }\end{array}$ & FBDS & 2011 \\
\hline $\begin{array}{c}\text { Políticas e Práticas Socioambientais nas } \\
\text { Instituições Financeiras }\end{array}$ & Instituto Ethos e BCB & 2012 \\
\hline $\begin{array}{c}\text { Introdução ao Setor Bancário Brasileiro e suas } \\
\text { Práticas de Sustentabilidade }\end{array}$ & Amigos da Terra e BankTrack & \multirow{2}{*}{} \\
\hline
\end{tabular}




\subsection{Análise dos dados}

Para a análise dos dados, foram seguidas as recomendações propostas por Eisenhardt (1989) para estudos de casos. Primeiro, foram levantados todos os dados relativos ao caso. Essa etapa consiste basicamente em descrições, porém são importantes para formação de insights, pois ajudam o investigador, no início do processo, a lidar com grandes quantidades de informações. A ideia é que o investigador se familiarize com o caso. Nessa etapa, todos os dados secundários foram analisados por meio de notas, documentos e tabelas feitas a partir das leituras. Além disso, todas as entrevistas foram transcritas.

A segunda etapa consistiu na procura de padrões entre os dados. Essa etapa é necessária, pois as pessoas tendem a tirar conclusões baseadas em poucos dados, a se influenciar por respondentes mais entusiasmados ou elitizados e, muitas vezes, a ignorar evidências que contrariam suas ideias. A solução para esse viés é analisar os dados de diversas perspectivas (EISENHARDT, 1989). Para seguir essa recomendação foi feita a triangulação de dados entre as entrevistas, os relatórios de sustentabilidade da empresa, artigos e relatórios de outras instituições.

A etapa seguinte da análise foi a comparação dos achados com a literatura existente. Esse passo consistiu em encontrar as similaridades e as contradições entre os achados do presente trabalho e dos demais. As similaridades aumentam a validade interna, a possibilidade de generalizações e reforçam a teoria. As contradições são importantes, pois não devem ser ignoradas pelos investigadores e também podem apresentar oportunidades de reformulação de ideias. (EISENHARDT, 1989). Nessa etapa os dados foram comparados tanto com o referencial teórico quanto com pesquisas relacionadas à RSC no setor bancário realizadas por outras instituições.

\subsection{Validade e Confiabilidade da Pesquisa}

Segundo YIN (2010), para estabelecer a qualidade da pesquisa social empírica, quatro testes são utilizados comumente: 
a) validade do constructo: utilizar as medidas operacionais corretas para os conceitos que estão sendo estudados, ou seja, garantir que o constructo esteja medindo aquilo que se deseja medir.

b) validade interna: garantir que as inferências do pesquisador, baseadas nas entrevistas e na evidência documental, que um determinado evento resultou de alguma ocorrência anterior estejam corretas.

c) validade externa: definir o domínio para o qual as descobertas do estudo podem ser generalizadas. No estudo de caso, trata-se da generalização analítica e não estatística, ou seja, o investigador luta para generalizar um conjunto determinado de resultados a alguma teoria mais ampla.

d) confiabilidade: demonstrar que as operações de um estudo, como os procedimentos para a coleta de dados, podem ser repetidas, obtendo-se os mesmos resultados. Trata-se, aqui, de realizar o mesmo caso novamente e não de "replicar" os resultados de um caso realizando outro Estudo de Caso. A meta da confiabilidade é minimizar os erros e as parcialidades no estudo.

Os quatro testes, seus respectivos objetivos e táticas que foram utilizadas para alcançá-los são mostrados no Quadro 13.

Quadro 13 - Testes que garantem a qualidade da pesquisa social empírica.

\begin{tabular}{|c|c|c|}
\hline Teste & Objetivo & Tática \\
\hline Validade do constructo & $\begin{array}{l}\text { Medir corretamente o que se propõe } \\
\text { medir. }\end{array}$ & $\begin{array}{c}\text { Usar múltiplas fontes de evidência. } \\
\text { Estabelecer o encadeamento de } \\
\text { evidências. } \\
\text { Ter informantes-chave. }\end{array}$ \\
\hline Validade interna & $\begin{array}{l}\text { Garantir que as inferências sobre as } \\
\text { relações causais estejam corretas. }\end{array}$ & $\begin{array}{l}\text { Realizar a combinação de padrão. } \\
\text { Realizar a construção da explanação. } \\
\text { Abordar as explanações rivais. } \\
\text { Usar modelos lógicos. }\end{array}$ \\
\hline Validade externa & $\begin{array}{c}\text { Definir o domínio das possíveis } \\
\text { generalizações analíticas do estudo. }\end{array}$ & $\begin{array}{c}\text { Usar a teoria. } \\
\text { Usar a lógica da replicação. }\end{array}$ \\
\hline Confiabilidade & $\begin{array}{l}\text { Garantir que, se um pesquisador, } \\
\text { posteriormente, seguir os mesmos } \\
\text { procedimentos do estudo, obterá os } \\
\text { mesmos resultados. }\end{array}$ & $\begin{array}{l}\text { Usar o protocolo do estudo de caso. } \\
\text { Desenvolver uma base de dados. }\end{array}$ \\
\hline
\end{tabular}

FONTE: Adaptado de YIN (2010) 


\subsection{Limitações da Pesquisa}

A estratégia de Estudo de Caso apresenta algumas limitações. A principal delas é a impossibilidade de generalizações dos resultados encontrados para populações maiores ou para situações mais gerais. Yin (2010) ressalta que os estudos de caso são generalizáveis às proposições teóricas e não às populações ou aos universos. Nesse sentido, o Estudo de Caso não representa uma "amostragem" e sua meta é expandir e generalizar teorias (generalização analítica) e não enumerar frequências (generalização estatística).

A segunda limitação importante se refere ao viés do pesquisador. De acordo com Eisenhardt (1989), as pessoas são "más processadoras" de informações e podem tirar conclusões baseadas em poucos dados, se influenciar por respondentes mais entusiasmados ou elitizados e, muitas vezes, ignorar evidências que contrariam suas ideias. Para diminuir o efeito dessa limitação, o pesquisador deve abordar as informações de diversas perspectivas e coletar dados de diferentes fontes, para que padrões possam ser encontrados.

\subsection{Modelo Conceitual da Pesquisa}

O modelo conceitual da pesquisa explora as conexões entre o referencial teórico e o problema de pesquisa. É também o modelo mental que o pesquisador leva ao campo para orientar o processo de coleta de dados e, posteriormente, da análise. A Ilustração 7 representa o modelo conceitual do presente estudo. 


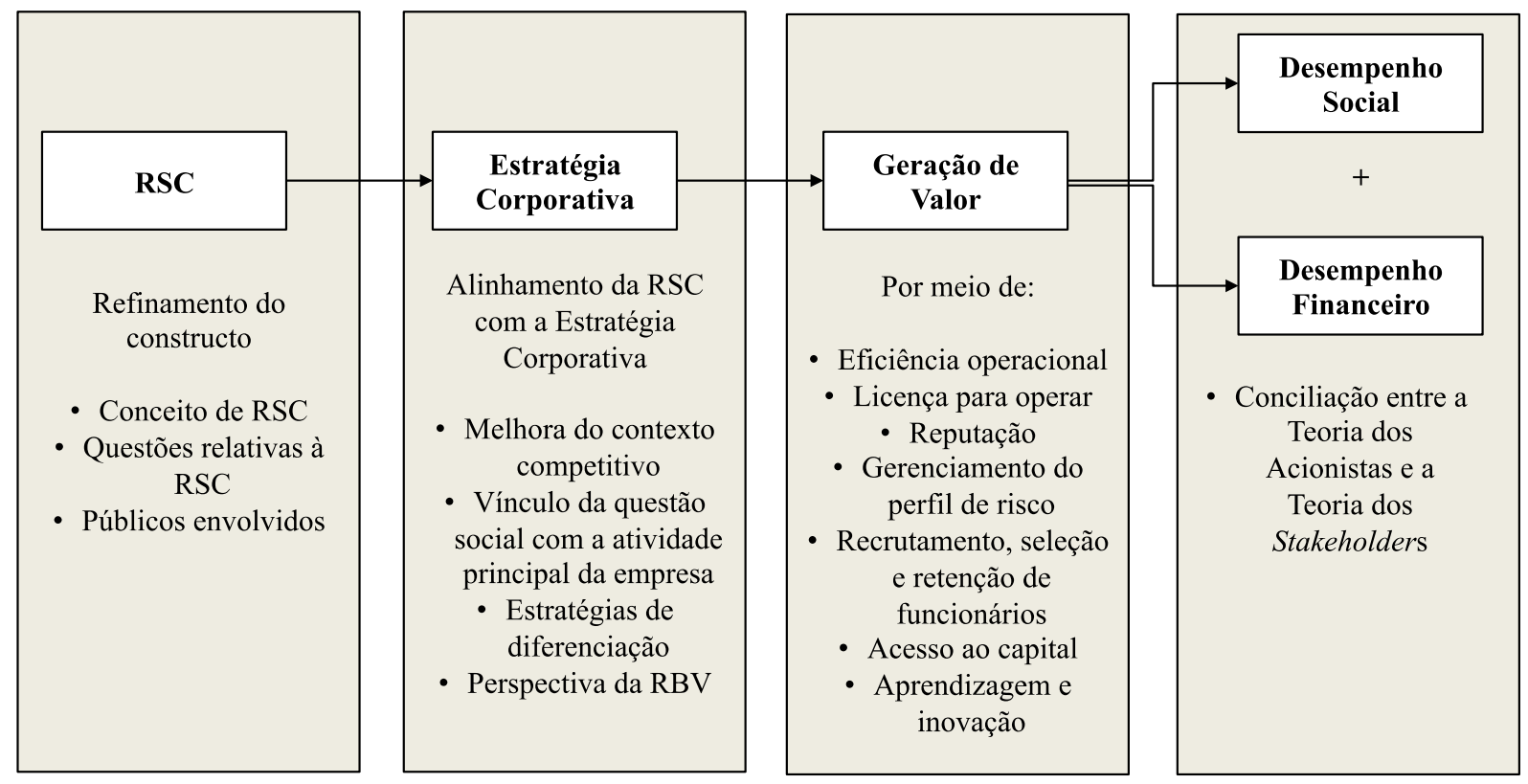

Ilustração 7 - Modelo conceitual da pesquisa.

\subsection{Definições dos Conceitos Relevantes}

Foram adotadas as seguintes definições dos conceitos relevantes ao estudo:

Responsabilidade é "a possibilidade de prever os efeitos do próprio comportamento e de corrigi-lo com base em tal previsão" (ABBAGNANO, 2007, p.855). A noção de responsabilidade baseia-se na de escolha, e a noção de escolha é essencial ao conceito de liberdade limitada. No caso da necessidade, a previsão dos efeitos não poderia influir na ação, e como tal previsão não poderia influir na ação no caso da liberdade absoluta, o sujeito se tornaria indiferente à previsão. Portanto, o conceito de responsabilidade inscreve-se em determinado conceito de liberdade, e mesmo na linguagem comum chama-se alguém de "responsável" ou elogia-se seu "senso de responsabilidade", quando se pretende dizer que a pessoa em questão inclui nos motivos de seu comportamento a previsão dos possíveis efeitos dele decorrentes (ABBAGNANO, 2007).

Responsabilidade Social é "a responsabilidade daquele que é chamado a responder pelos seus atos face à sociedade ou à opinião pública, na medida em que tais atos assumam dimensões ou consequências sociais" (BIROU, 1976, p. 361). 
Responsabilidade Social Corporativa é a responsabilidade da empresa que é chamada a responder pelos seus atos face à sociedade ou à opinião pública, na medida em que tais atos assumam dimensões ou consequências sociais. Essa definição foi elaborada baseando-se na definição de Birou (1976) para responsabilidade social.

Desenvolvimento Sustentável ou Sustentabilidade é atender às necessidades da geração atual sem comprometer a possibilidade das gerações futuras suprirem suas próprias necessidades. Esse conceito foi elaborado pelo relatório Brundtland, realizado pela WCED, da ONU, em 1987.

Responsabilidade Social Corporativa Estratégica é a inserção da variável social ao longo de todo o processo gerencial de planejar, organizar, dirigir e controlar, utilizando-se das funções organizacionais como marketing, produção, finanças, recursos humanos e outras, bem como das interações que ocorrem no mercado, visando a atingir os objetivos e metas organizacionais. (NASCIMENTO et al., 2008)

Estratégia Organizacional é a determinação de metas e objetivos básicos e de longo prazo da empresa; e a adoção de ações e alocação de recursos necessários para atingir esses objetivos (CHANDLER, 1962). 


\section{ANÁLISE E DISCUSSÃO DOS RESULTADOS}

\subsection{Apresentação do Itáu Unibanco}

A empresa tem suas origens no ano de 1924, quando o Unibanco foi fundado pela família Moreira Salles em Poços de Caldas. Naquele ano, o comerciante João Moreira Salles obteve carta-patente para a Casa Moreira Salles. A empresa era um magazine que, além de comercializar mercadorias variadas - artigos de armarinho, para a lavoura, de cozinha, vestuário -, operava uma seção bancária. Na virada da década de 1920, o empresário já atuava como correspondente de mais de uma dezena de grandes bancos e contava com mais de duas centenas de clientes, entre cafeicultores e empreendedores da atividade turística na cidade.

O governo brasileiro, pouco antes, dera início a uma reorganização do sistema bancário. $\mathrm{O}$ carro-chefe da reforma foi a criação da Carteira de Redesconto do Banco do Brasil, que ganhava a condição de garantidor da liquidez do sistema, medida à qual se seguiram a instituição do serviço de compensação de cheques, também de responsabilidade do banco oficial, e a definição de normas de fiscalização dos bancos. Foi nesse ambiente que, em 1923, a Casa Moreira Salles registrou um crescimento em grande parte por causa de sua atividade bancária.

O Banco Itaú teve origem em 1944 com a família Egydio de Souza Aranha, na capital paulista. Assim como o Unibanco, a instituição nasceu pelas mãos de um empreendedor de outro setor, numa época de efervescência econômica por meio da indústria e da reestruturação do sistema bancário nacional. A primeira agência, inaugurada em 2 de janeiro de 1945, no centro de São Paulo, começou a funcionar no ano em que o governo criou a SUMOC, do Banco do Brasil, o embrião do BCB, formalizado duas décadas depois.

Com o fim da Segunda Guerra Mundial, a atividade industrial ganhou força. A partir da ampla rede de relacionamentos de Souza Aranha com industriais e comerciantes têxteis, o Central de Crédito deu início a um primeiro ciclo de expansão. Em dez meses, o banco incorporou uma agência em Campinas e outra em São João da Boa Vista. No ano seguinte, aumentou seu capital, para suportar a construção de uma nova sede, no centro de São Paulo, e 
a abertura de novas agências, no interior paulista.

Em 1940, a fusão entre a Casa Bancária Moreira Salles, a Casa Bancária de Botelhos e o Banco Machadense, todos do Sul Mineiro, cria o Banco Moreira Salles, reunindo 34 sucursais e agências. Cinco anos depois, já havia 63, distribuídas por São Paulo, Minas Gerais e Rio de Janeiro. A partir da segunda metade dos anos 60, começou um período de crescimento por incorporação ou fusão com outras instituições.

O Central de Crédito ficou restrito ao Estado de São Paulo até o final da década de 50, quando somava 31 agências. Nas décadas seguintes, o banco continuou crescendo, conduzido pelo engenheiro Olavo Egydio Setubal, que, a convite de seu tio Alfredo Egydio de Souza Aranha, assumiu a Diretoria do Banco Federal de Crédito, e por Eudoro Villela, médico e genro de Alfredo Egydio. A partir dos anos 60, o banco viveu uma forte expansão, principalmente, por meio de associações e aquisições de outros bancos. Em 1964, ocorreu a fusão com o Banco Itaú S.A., então um dos 50 maiores bancos brasileiros e, em 1966, com o Banco Sul Americano do Brasil S.A., da família Moraes Barros, dando origem ao Banco Federal Itaú Sul Americano. Em 1969, ocorreu a fusão com o Banco da América, inovador na prestação de serviços à clientela de maior renda. Depois foram o Banco Aliança S.A., em 1970, o Banco Português do Brasil S.A., em 1973, e o Banco União Comercial S.A., em 1974.

Ao final desse período, o banco ocupava o segundo lugar em volume de depósitos de todo o sistema bancário nacional e era líder, entre as instituições privadas, em número de agências, com quase 500 unidades espalhadas pelo país. Seu nome, daí em diante, seria Banco Itaú S.A.

Enquanto isso, o Banco Moreira Salles, que, em 1967, já somava mais de 300 agências e cerca de um milhão de correntistas, muda sua denominação para União de Bancos Brasileiros, a partir da incorporação do gaúcho Banco Agrícola Mercantil, presente em nove estados e no Distrito Federal. É com esse nome que, em 1970, assume o Banco Predial, do Rio de Janeiro, instituição especializada em crédito popular, que lhe deu grande capilaridade nos então estados do Rio de Janeiro e da Guanabara. Em 1974, o grupo inaugurou, em Paris, a primeira das suas agências no exterior.

Um novo ciclo de fusões e incorporações ocorreu em seguida ao Plano Real, em meados dos anos 90, quando, finalmente, o processo hiperinflacionário foi vencido. O Itaú e Unibanco já 
estavam organizados, como bancos múltiplos, e com atuação segmentada pelos diversos tipos de clientes - pessoas físicas, com suas subdivisões por faixas de renda, e empresas, estas divididas pelo porte dos negócios - e por áreas de serviços oferecidos - banco de investimentos, seguradoras, financeiras, crédito imobiliário, corretoras e distribuidoras de valores.

A estratégia de ambas as instituições, nesse momento, era absorver grandes concorrentes que não conseguiram superar a complicada transição de um ambiente econômico de hiperinflação para outro, em que os preços se encontravam sob controle, além de incorporar grandes bancos estaduais, em processos de privatização. Em 1995, o Itaú adquiriu o Banco Francês e Brasileiro e, nos anos seguintes, incorporou, sucessivamente, os estaduais BANERJ (Banco do Estado do Rio de Janeiro), BEMGE (Banco do Estado de Minas Gerais), BANESTADO (Banco do Estado do Paraná) e BEG (Banco do Estado de Goiás). Atendendo à estratégia de segmentação de mercado, em 2002, associou-se ao Banco BBA-Creditanstalt, ativo no segmento de grandes clientes corporativos; em 2003, comprou o Banco Fiat S.A., especializado em financiamento de veículos; e, em 2006, as operações do BankBoston no Brasil, Chile e Uruguai.

Também em 1995, o Unibanco absorveu, em prazo curto, a complexa estrutura do Banco Nacional S.A., então sob intervenção federal. Nos anos seguintes, também incorporou várias instituições, em diferentes segmentos do mercado financeiro. Vieram, assim, a fazer parte do conglomerado Unibanco, a financeira Fininvest, líder em crédito direto ao consumidor (metade do capital adquirido em 1996 e aquisição completada em 2000) e o Banco Dibens, forte no financiamento de veículos (metade em 1998 e a integralidade em 2005). Pouco depois, em 2000, o Unibanco incorporou o Credibanco e o Banco Bandeirantes. Ainda haveria outras incorporações, nos anos seguintes, como do Banca Nazionale del Lavoro (BNL) do Brasil, subsidiária da italiana Banca Nazionale del Lavoro SpA, em 2004.

Em 2008, as duas instituições celebraram uma associação que deu origem ao Itaú Unibanco Holding S.A. Em 31/12/2012, a empresa contava com 96.977 colaboradores, sendo 90.323 no Brasil e 6.654 no exterior. As ações da empresa são negociadas BM\&FBOVESPA, na Bolsa de Valores de Nova Iorque (NYSE) e na Bolsa de Comércio de Buenos Aires (BCBA). Os padrões contábeis utilizados são: Generally Accepted Accounting Principles (BR GAAP), 
exigido pelo BCB, e International Financial Reporting Standards (IFRS) - padrão internacional exigido pela Comissão de Valores Mobiliários (CVM).

A atuação da empresa no mercado brasileiro abrange todas as regiões do país, com 5.027 agências e postos de atendimento bancário. No exterior, atua em 19 países, 7 deles na América Latina, com o objetivo de atender tanto os clientes locais quanto os brasileiros que necessitam de produtos e serviços bancários fora do Brasil. Em 2012, o lucro líquido do banco foi R\$ 13,6 bilhões, o Return on Equity (ROE) 19,4\% e seus ativos somavam R\$1,014 trilhão. O Quadro 14 mostra os principais indicadores financeiros da instituição em 2012.

Quadro 14 - Principais indicadores financeiros da instituição em 2012.
\begin{tabular}{|c|c|}
\hline Ativos totais & $1.014,40$ (R $\$$ bilhões) \\
\hline $\begin{array}{c}\text { Operações de crédito com avais e } \\
\text { fianças }\end{array}$ & 426,6 (R \$ bilhões) \\
\hline Saldo de PDD & 27,7 (R \$ bilhões) \\
\hline Patrimônio líquido & $74,2(\mathrm{R} \$$ bilhões) \\
\hline $\begin{array}{c}\text { Recursos próprios livres, captados e } \\
\text { administrados }\end{array}$ & $1.449,2$ (R \$ bilhões) \\
\hline Margem financeira & $52,0(\mathrm{R} \$$ bilhões) \\
\hline Lucro líquido & $13,6(\mathrm{R} \$$ bilhões) \\
\hline Índice de Basileia & $16,7(\%)$ \\
\hline Índice de eficiencia & $45,4(\%)$ \\
\hline ROE & $19,4(\%)$ \\
\hline Valor patrimonial por ação & $16,4(\%)$ \\
\hline Lucro por ação & $3,11(\mathrm{R} \$)$ \\
\hline
\end{tabular}

FONTE: Baseado em ITAÚ UNIBANCO, 2012.

Atualmente, os negócios do banco incluem:

Banco Comercial: abrange seguros, planos de previdência e produtos de capitalização, cartões de crédito, gestão de ativos e diversos produtos e serviços de crédito para pessoas físicas e pequenas e médias empresas. A rede de atendimento de varejo no Brasil é composta por 4.731 agências e postos de atendimento. A rede de varejo atende mais de 15 milhões de correntistas.

Itaú BBA: é um banco de atacado, de investimentos e tesouraria institucional, responsável pelas operações bancárias do segmento corporativo e de banco de investimentos. Realiza tanto operações típicas de um banco comercial quanto transações em mercados de capitais, fusões e aquisições. Tem como clientes mais de três mil dos maiores grupos empresariais do Brasil, 
Argentina, Chile, Colômbia e Peru. Também atende cerca de 700 investidores institucionais e possui clientes internacionais por meio das unidades na Europa, nos Estados Unidos e na China. Uma das frentes de atuação mais importantes para o Itaú BBA é o conjunto de iniciativas ligadas à melhoria da eficiência em operações. As ações contínuas estão ligadas a incremento das receitas, aperfeiçoamento dos processos e redução de custos.

Crédito ao Consumidor: abrange produtos e serviços financeiros para não correntistas, cartão de crédito, financiamento de veículos, microcrédito. A empresa é líder no segmento de cartões de crédito no Brasil, por meio da Itaucard, da Hipercard, e de associações e dos acordos comerciais com varejistas que atuam no mercado brasileiro, totalizando 33,3 milhões de contas de clientes correntistas e não correntistas. O segmento reúne a operação de cartões de crédio e os serviços financeiros oferecidos por meio de parcerias com redes varejistas. A segmentação organiza os canais de distribuição em operações dedicadas à rede de agências, canais diretos e associações.

Credenciamento e Adquirência: compreende o processo de captura das transações com cartões de crédito e débito, cartões de benefícios (voucher) e de lojas (private label) por intermédio da filiação, do gerenciamento e do relacionamento com os estabelecimentos comerciais, por meio das empresas Hipercard e Redecard. Inclui serviços de antecipação de recebíveis, disponibilização de terminais, consulta de cheques, compra e saque, serviços não financeiros e extrato eletrônico.

Mercado e Corporação: área que viabiliza as operações provenientes de clientes e o gerenciamento de caixa e posições institucionais. A área de Tesouraria Institucional presta serviços a todo o banco, viabilizando as operações advindas de clientes e o gerenciamento de caixa e posições institucionais. A área é responsável por zelar pela liquidez, estabelecer as bases de preços para as áreas comerciais de atacado, varejo e mercado de capitais, gerar resultados por meio da administração ativa de riscos de mercado e estruturar e executar as captações próprias do conglomerado.

O Gráfico 7 mostra a participação de cada área de negócio no lucro líquido recorrente do banco em 2012. 


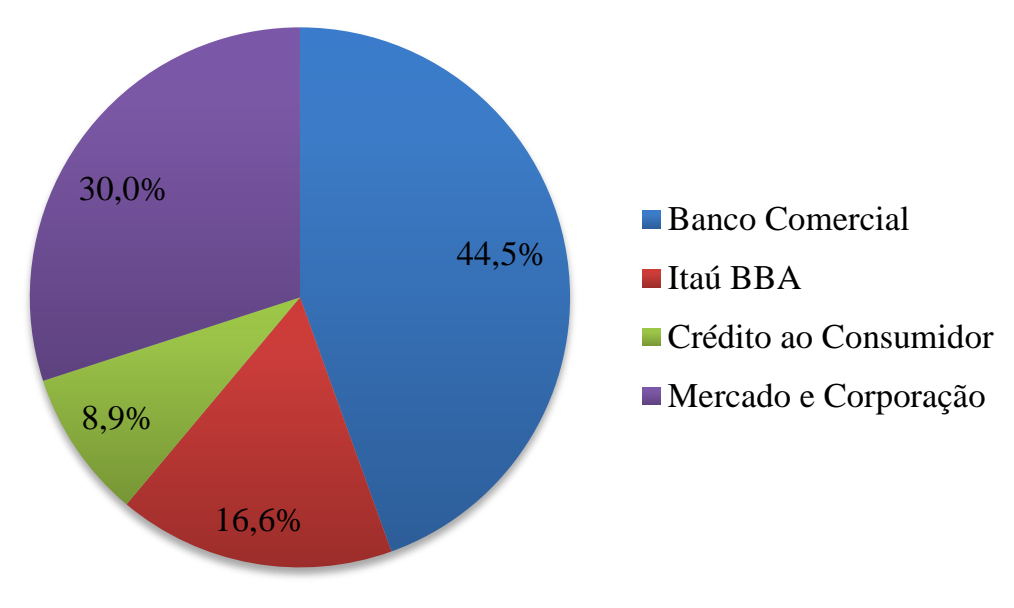

Gráfico 7 - Composição do lucro líquido recorrente do Itaú Unibanco em 2012. FONTE: Baseado em ITAÚ UNIBANCO, 2012.

\title{
4.2 RSC para o Itaú Unibanco
}

Atualmente, a RSC no Itaú Unibanco é tratada, principalmente, por meio do conceito de Sustentabilidade. Para a empresa, Sustentabilidade é "a manutenção dos negócios no curto, médio e longo prazo para uma entrega perene de valor às partes interessadas." (ITAÚ UNIBANCO, 2010, p. 30).

\begin{abstract}
Essa visão implica estruturar um modelo de gestão que, concomitantemente com a busca do desempenho para os acionistas e demais públicos, também considera e administra positivamente o impacto de suas operações no meio ambiente e na sociedade. [...] Adotar essa postura representa um grande desafio para qualquer organização, pois significa olhar para além de suas atividades diárias e fazer com que seus produtos e serviços atendam às necessidades de seus clientes de maneira satisfatória e contribuam para a conscientização e o desenvolvimento justo da sociedade. (ITAÚ UNIBANCO, 2012, p.10)
\end{abstract}

$\mathrm{Na}$ visão da entrevistada E1, a RSC dos bancos é um movimento que começou com Investimento Social Privado, caminhou por algumas ondas, como governança corporativa, e está agora na sua onda mais recente, que é a sustentabilidade. Ela exemplifica com a questão da governança corporativa, afirmando que há quinze anos ninguém imaginaria que a qualidade da gestão da empresa seria avaliada e seu impacto no valor da ação medido, porém hoje isso é feito em todos os índices de Bolsas de Valores.

A gente vê a sustentabilidade como um desses últimos movimentos, não é a última onda mas é a mais recente. Como é que você sendo empresa, qual sua capacidade de permanecer na escolha das pessoas e fazer os seus negócios considerando o contexto onde você está envolvido, o que é muito mais amplo do que simplesmente gerar lucro [...] como é que você faz negócios em um ambiente 
que tem questões ambientais que impactam o resultado das pessoas, da sua empresa e tudo mais. (E1)

Ao ser questionada sobre qual a responsabilidade social das empresas, a entrevistada E1 afirma que:

[...] depende do que ela faz e como o que ela faz está inserido na sociedade e no ambiente onde ela opera [...] No setor financeiro, a maior cobrança é sobre influência [...] Qual sua capacidade de influenciar uma pessoa ou de direcionar uma escolha certa ou errada de crédito? [...] Para cada setor da economia, você vai ter uma responsabilidade chave [...] Para o setor de mineração é resíduo, é agua [...] Para bancos, é capacidade de influência.

A entrevistada E2, ao tratar da responsabilidade do banco, também destaca o poder de influência.

[...] essa percepção de [...] tenho que influenciar o mercado de uma forma positiva, tenho que olhar lá para frente [...] não só com relação ao termo sustentabilidade, mas contribuir efetivamente para o país. Esse tipo de pensamento passou a ser muito latente na organização a partir do momento que ela assumiu uma posição de liderança no setor bancário [...] A gente está com 40 milhões de clientes...é muita gente. Eu sou significativo nessa engrenagem [...] então vem uma questão de responsabilidade, de papel do líder [...] independentemente de ter o nome sustentabilidade por trás ou não. [...]

Qual é o papel social do banco? [...] Olha o volume de recursos que a gente movimenta na economia e a capacidade de influenciar essa economia a partir dessa movimentação de recursos. Escolhas de crédito ou de investimento que a gente faz [...] influenciam o desenvolvimento do país.

No discurso das entrevistadas, há elementos que se encontram nas primeiras discussões a respeito da RSC. Desde a década de 1950, discutem-se quais são as responsabilidades das empresas e dos homens de negócios. Já existia a ideia de que as maiores empresas são centros de poder e decisões e que suas ações impactam na vida dos cidadãos de diversas formas. (CARROLL, 2008)

Segundo a entrevistada E1, os bancos têm o papel de organizar os fluxos financeiros na economia e, dentro desse papel, podem incorporar os critérios socioambientais e privilegiar os clientes e forncedores que estão adotando melhores práticas. O banco é capaz de influenciar quem não está adotando boas práticas, por exemplo, ao exigir uma licença ambiental ou uma declaração que não mantém trabalhadores em condições análogas à de escravo. Considerar esses critérios faz que o banco seja um agente importante para promover a Sustentabilidade. Essa influência ocorre de um jeito muito pragmático, afetando, positivamente, o resultado da 
empresa.

Apesar de acadêmicos ainda discutirem se a empresa deve se envolver em questões socioambientais ou não, e alguns (FRIEDMAN, 1970; LAZONICK; O'SULLIVAN, 2000; KARNANI, 2011) defenderem que o envolvimento em tais práticas representa desvios financeiros, na visão da entrevistada E1, o questionamento sobre a importância da sustentabilidade não existe mais, principalmente, em grandes empresas e empresas líderes de mercado. A grande questão agora é "como" e "quando" fazer.

\begin{abstract}
Não tem conhecimento, o conhecimento está sendo construído junto com o entender do problema. Então esse default de expertise é uma das grandes dificuldades hoje de se mover isso mais rapidamente. Porque você não tem. Você tem a medicina com 600 anos de história, economia com 250 e sustentabilidade com 30. Não tem ciência suficiente para eu ter metade das respostas que eu precisaria. Então, esse é um dos "complicômetros", mas definitivamente é uma questão de "como" e "quando".
\end{abstract}

\title{
4.3 Alinhamento entre RSC e Estratégica Organizacional
}

\subsubsection{Processo de Elaboração da Nova Visão e Cultura}

Em 2008, quando ocorreu a fusão do Itaú e Unibanco, a empresa considerou que esse seria o momento certo para disseminar uma nova cultura e construir uma nova visão. Nessa ocasião, os gestores consideraram os valores utilizados pelo Itaú e pelo Unibanco em suas trajetórias, e o que desejavam para o futuro. Houve uma combinação das duas culturas com novos desafios e posturas. Ao longo do processo, mais de 16 mil colaboradores, de áreas administrativas e da rede de agências, foram ouvidos, por meio de pesquisas quantitativas e qualitativas. O debate também passou pelo Comitê de Pessoas, órgão do Conselho de Administração, e o desenho da nova cultura corporativa foi validado em mais de uma sessão do Comitê Executivo. (ITAÚ UNIBANCO, 2010)

A entrevistada E3 explica esse processo com mais detalhes afirmando que, na fusão, uma das principais preocupações do Presidente Executivo, Roberto Setubal, e do Presidente do Conselho de Administração, Pedro Moreira Salles, foi pensar em que cultura e que identidade eles queriam para o novo banco. Para isso, a area de cultura corporativa passou uma pesquisa de valores para colaboradores de ambos os bancos perguntando o seguinte: Quais são os 
valores que vocês têm hoje e quais são os valores que vocês querem para o novo banco?

A entrevistada E3 conta que as respostas sobre os valores que os colaboradores tinham foram distintas, porém as respostas sobre os valores que eles desejavam para o novo banco foram convergentes. A única diferença foi que, no Itaú, o item performance foi citado e, no Unibanco, foco no resultado. Porém, a gerente acredita que a distinção entre os dois termos é apenas uma questão de prazo, pois performance remete a um prazo maior e foco no resultado, a um mais curto.

Os resultados dessa pesquisa foram levados ao Comitê Executivo e, a partir deles, foram criadas as dez atitudes que a empresa chama de "Nosso Jeito de Fazer", que é a cultura do Banco, é o que o ele quer ser. Na mesma ocasião, foi criada a nova visão. A gestora E3 explica que esse processo teve dois momentos, pois, quando a cultura e a visão estavam $70 \%$ prontas, foram feitos grupos focais. Os próprios Roberto Setubal e Pedro Moreira Salles participaram de alguns desses grupos e o pessoal da área de cultura visitou o Brasil inteiro para perguntar se os colaboradores entendiam e se reconheciam nessa visão e cultura. De acordo com as palavras da entrevistada E3: "a visão é onde queremos chegar e o 'Nosso Jeito de Fazer' é como a gente vai chegar lá."

Assim, a nova cultura do Banco passou a ser expressa pelo que a empresa chama de "Nosso Jeito de Fazer", que é um conjunto de dez atitudes que direcionam como as equipes realizam os negócios e atuam para consolidar a visão. As dez atitudes escolhidas foram: Todos pelo cliente; Paixão pela performance; Craques que jogam para o time; Foco na inovação e inovação com foco; Processos servindo pessoas; Ágil e descomplicado; Carteirada não vale; Brilho nos olhos; Sonho grande; Liderança ética e responsável. (ITAÚ UNIBANCO, 2012)

O Itaú Unibanco passou a ter uma visão única: "Ser o banco líder em performance sustentável e em satisfação de clientes". A antiga visão do Itaú era: "Ser o banco líder em performance e perene, reconhecidamente sólido e ético, destacando-se por equipes motivadas, comprometidas com a satisfação dos clientes, com a comunidade e com a criação de diferenciais competitivos". No Unibanco, de acordo com a entrevistada E3, não havia uma visão de fato e trabalhava-se mais com metas institucionais e desafios que se alteravam ao longo do tempo conforme a evolução. A Ilustração 8 mostra a antiga e a nova visão da empresa. A entrevistada E3 justifica a mudança: “A visão do Itaú antes da fusão era bem 
complexa e bem comprida. As pessoas se confundiam e se questionavam: O que eu quero ser de fato? Qual o nosso foco?"

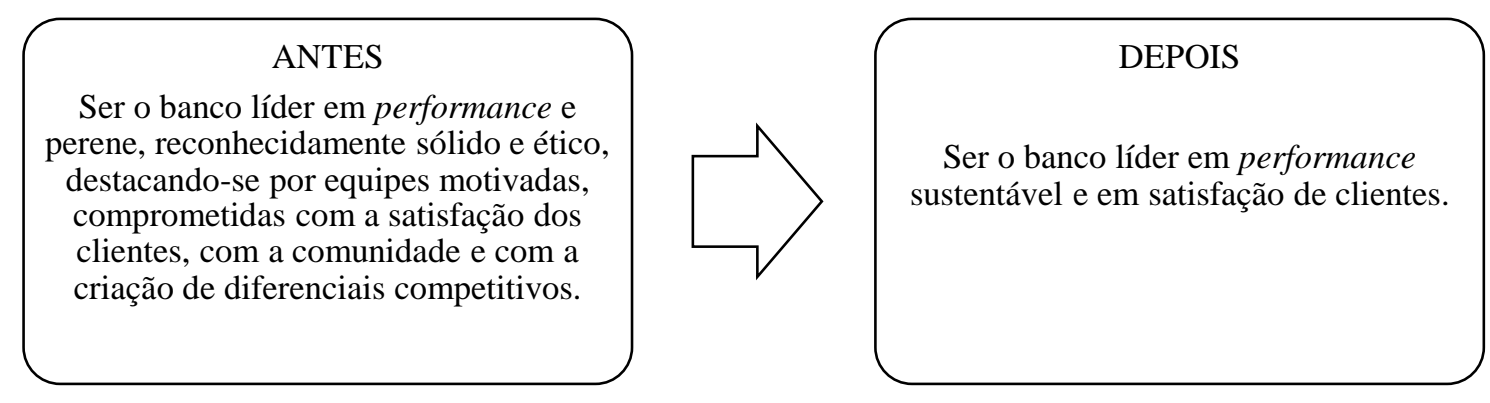

Ilustração 8 - Mudança da visão do Itaú Unibanco.

A empresa não possui missão, pois acredita que tira o foco do que considera mais importante, que é a visão e o "Nosso Jeito de Fazer". Cada área de negócios pode ter a sua missão, a qual deve passar pela visão, cultura e valores. Porém, a entrevistada E3 explica que a empresa não incentiva que as áreas tenham missão.

\begin{abstract}
A gente não incentiva muito as áreas a terem uma missão porque a gente quer que as pessoas e as áreas tenham um objetivo, que é o objetivo do banco e não seus objetivos. Uma vez que eu tenho missões muito separadas [...] eu vou ficar verticalizando, cartões tem essa visão, varejo tem essa visão, pode ser que dê conflito. Então não, a visão que a gente tem que ter é: ser o banco líder em performance sustentável e em satisfação de clientes.
\end{abstract}

A divulgação da visão do Itaú Unibanco e do "Nosso Jeito de Fazer" ocorreu no Encontro de Líderes, realizado em São Paulo, em fevereiro de 2010. No evento, o Presidente do Conselho de Administração, Pedro Moreira Salles, e o Presidente Executivo, Roberto Setubal, discursaram, para uma platéia de 14 mil lideranças do banco, seu papel fundamental na prática dos valores e atitudes. (ITAÚ UNIBANCO, 2010)

Ao falar sobre a divulgação da visão e da cultura no Banco, a entrevistada E3 explica que realmente começou no Encontro, pois os líderes saíram de lá com a responsabilidade de discutir isso com suas equipes. Houve também duas rodadas de oficinas do "Nosso Jeito de Fazer", nas quais toda a liderança participou. Além disso, para as equipes, foi feito um mapa de aprendizagem. O mapa era um jogo que possuia o desenho de um rally com diversas situações. Cada uma das estações do jogo representava uma das dez atitudes. Então as pessoas faziam uma reflexão e discussão em cima desse mapa. Foi feito também um trabalho com as áreas executivas, pois cada uma estava em um nível de incorporação diferente. Além disso, a 
comunicação de todo o banco foi revisada e a linguagem do "Nosso Jeito de Fazer" foi divulgada em comunicados, tablets gigantes, televisões, etc.

A entrevistada E3 ressalta que até hoje continuam trabalhando na disseminação da visão e cultura. Antes de novos colaboradores entrarem no banco, é feita uma avaliação para verificar se a pessoa tem perfil compatível com a visão e cultura. Para os novos colaboradores, há uma integração em que as dez atitudes são reforçadas.

Atualmente, a cada ano a empresa prioriza algumas das dez atitudes e não trabalha mais todas igualmente. A divulgação das dez atitudes foi feita no primeiro ano. No segundo e terceiro anos, a empresa focou em Meritrocracia e Eficiência e, em 2012, escolheu Ágil e Descomplicado como temas estratégicos.

O Quadro 15 mostra as declarações da empresa sobre sua visão, cultura e sustentabilidade.

Quadro 15 - Declarações da empresa.

\begin{tabular}{|c|c|}
\hline Item & Descrição \\
\hline Visão & Ser o banco líder em performance sustentável e em satisfação de clientes. \\
\hline Cultura & $\begin{array}{c}\text { Nossa cultura é expressa pelo chamado "Nosso Jeito de Fazer", um conjunto de dez } \\
\text { atitudes que direcionam como nossas equipes realizam nossos negócios e atuam para } \\
\text { consolidar nossa visão. }\end{array}$ \\
\hline $\begin{array}{c}\text { O “Nosso Jeito } \\
\text { de Fazer" }\end{array}$ & $\begin{array}{c}\text { Todos pelo cliente; Paixão pela performance; Craques que jogam para o time; Foco na } \\
\text { inovação e inovação com foco; Processos servindo pessoas; Ágil e descomplicado; } \\
\text { Carteirada não vale; Brilho nos olhos; Sonho grande; Liderança ética e responsável. }\end{array}$ \\
\hline $\begin{array}{c}\text { Sustentabilidade } \\
\text { Performance }\end{array}$ & $\begin{array}{c}\text { É a manutenção dos negócios no curto, médio e longo prazo para uma entrega perene de } \\
\text { valor às partes interessadas. }\end{array}$ \\
\hline Sustentável
\end{tabular}

FONTE: Baseado em ITAÚ UNIBANCO, 2012.

\subsubsection{Estratégia de Sustentabilidade}

De acordo com o Relatório Anual de Sustentabilidade (2008), até o momento da associação, o Itaú e o Unibanco possuíam estratégias e visões de sustentabilidade similares, com ênfase na geração perene de valor, no compromisso com o desenvolvimento sustentável, e no relacionamento transparente com os públicos envolvidos ou afetados por suas operações. 
Com o objetivo de melhorar a qualidade de seu relatório de sustentabilidade, em outubro de 2008, o Itaú realizou duas sessões de consultas, com 62 representantes de grupos estratégicos para o banco. Entre os princípios mais importantes para a qualidade de um relatório de sustentabilidade, estão a inclusão dos stakeholders e a materialidade, isto é, a abordagem de temas e assuntos essenciais para a operação da empresa e para a sociedade. Na primeira consulta, um grupo de colaboradores apontou os temas mais importantes a serem tratados no relatório de sustentabilidade, na sua visão. A segunda etapa foi um painel de stakeholders, que incluiu a participação de colaboradores de diversas áreas da organização, clientes, fornecedores e representantes de ONGs e de outras instituições do setor financeiro. A esse grupo foi solicitada uma avaliação qualitativa e quantitativa do relatório anterior do banco, com ênfase nos pontos a melhorar. Os resultados dessas consultas foram consolidados por consultoria especializada, a BSD Consulting, que apresentou ao Itaú uma matriz de materialidade, com os principais assuntos que deveriam ser tratados. (ITAÚ UNIBANCO, 2008)

Além disso, outros três estudos contribuíram para eleger as prioridades do novo relatório. A consultoria inglesa SustainAbility, em parceria com a FBDS, realizou a primeira avaliação dos relatórios de sustentabilidade produzidos no Brasil. Ao mesmo tempo, o Unibanco realizou um estudo de benchmark sobre as práticas de relatórios do setor financeiro, no Brasil e no exterior. O cruzamento dos resultados das consultas aos stakeholders e dos apontamentos dos estudos sobre os relatórios de sustentabilidade foi consolidado e, posteriormente, enviado a um grupo de especialistas do mercado, da academia e de organizações ambientais e sociais. Esse grupo indicou quais temas, dentre o grupo inicial, deveriam ser considerados prioritários pela publicação. (ITAÚ UNIBANCO, 2008)

A empresa mostra um maior comprometimento em medir, divulgar e prestar contas para stakeholders internos e externos do seu desempenho social, ao se preocupar em melhorar a elaboração de seu relatório de sustentabilidade. O modelo de relatório de sustentabilidade utilizado pela empresa é o GRI, que defende que o documento deve oferecer uma descrição equilibrada e sensata do desempenho de sustentabilidade da organização relatora, incluindo informações positivas e negativas. (GRI, 2012)

Esse processo de construção de materialidade do relatório deu origem, em 2009, à publicação da Essência de Sustentabilidade, que resumia os principais desafios e prioridades do Itaú 
Unibanco no que se refere à sustentabilidade. A Essência da Sustentabilidade é um documento que explicita quais eram considerados os oito principais desafios para a gestão e sobre os quais estavam concentrados os maiores esforços na busca por uma atuação sustentável. Eram eles: a) Transparência e Governança; b) Satisfação dos Clientes; c) Critérios Socioambientais; d) Diversidade; e) Mudanças Climáticas f) Educação Financeira; g) Microfinanças; h) Engajamento de Stakeholders (ITAÚ UNIBANCO, 2009). Dessa forma, pode-se considerar que a Essência da Sustentabilidade era o posicionamento da empresa com relação à sustentabilidade até então.

A entrevistada E2 explica que, após a criação da Essência da Sustentabilidade, surgiu a necessidade de aprofundamento dessa agenda e de discutir como a empresa deveria atuar com relação a esses oito temas. Para isso, iniciou-se um processo de consulta de seus stakeholders para descobrir que questões eram mais relevantes para eles. Naquele momento, ainda não havia uma definição de cultura e de visão do banco. O feedback que receberam do paínel de stakeholders foi que os oito temas abrangiam coisas muito distintas, e que o banco precisaria priorizar mais e focar em questões mais ligadas ao seu negócio. Alguns dos temas eram transversais enquanto que outros eram mais específicos. Por exemplo, havia o tema de engajamento dos stakeholders - que é bastante transversal - e diversidade - que é muito específico.

Molteni (2006) acredita que uma das dificuldades encontradas pelas empresas é a identificação das expectitivas dos stakeholders, uma vez que as repercursões sociais de uma nova estratégia ainda não foram testadas. Para lidar com essa dificuldade, observou-se que o Banco criou um diálogo preliminar com seus stakeholders por meio dos painéis e workshops realizados. Após a identificação das expectativas, é possível encontrar soluções inovadoras para atendê-las.

Em 2010, houve a definição da marca, da cultura e da visão. De acordo com a entrevistada (E2), essa nova identidade da organização foi essencial para que a estratégia de sustentabilidade fosse revisada. A nova estratégia foi criada com base na nova identidade da organização, nos inputs dos stakeholders e em algumas referências externas que o banco tinha. Além disso, ao longo de 2011, cerca de 200 executivos, diretores e colaboradores foram envolvidos para discutir a seguinte questão: Quais são as prioridades do Itaú Unibanco em 
sustentabilidade e como vincular o tema à agenda de negócios da organização?

A ideia de vincular a RSC aos negócios também aparece na fala da entrevistada E1.

[...] não é uma coisa que eu faço antes das nove e depois das seis, como eu costumo dizer, é sobre o que eu faco das nove às seis. O que é diferente do movimento de Investimento Social Privado, que eu fazia com o resultado do que eu gerava de negócio das nove às seis. Hoje é sobre a empresa, um olhar muito mais para dentro.

Segundo o Relatório Anual de Sustentabilidade (2010), em 2009, a empresa intensificou um processo de reflexão e incorporação da sustentabilidade em todas as suas áreas, com o objetivo de alcançar um alinhamento transversal do tema na totalidade de suas operações e processos. Para atingir esse objetivo, o banco afirmava que:

\footnotetext{
O Itaú Unibanco se apoia em estratégias claras e bem definidas de atuação, em políticas que norteiam o relacionamento com os stakeholders, na transparência e ética nos negócios e na prestação de contas, além de uma sólida governança corporativa que insere progressivamente os conceitos da sustentabilidade em suas decisões. (ITAÚ UNIBANCO, 2010, p. 30)
}

No Relatório Anual de Sustentabilidade de 2011, a empresa passa a enfatizar a necessidade do alinhamento da sustentabilidade às estratégias dos negócios:

A estratégia de sustentabilidade de uma organização deve ser um processo de evolução contínua e de aprimoramento constante, a fim de alinhar as demandas e expectativas da sociedade com o posicionamento e as estratégias dos negócios. (ITAÚ UNIBANCO, 2011, p. 34)

Dessa forma, a empresa afirma que buscou integrar as necessidades sociais à sua estratégia de negócios, o que, segundo Molteni (2006), seria o nível mais alto de eficiência com que a empresa pode lidar com as demandas e expectativas da sociedade. A empresa mostra reconhecer que a interacão com seus stakeholders cria temas que promovem oportunidades e ameaças, conforme defendido por Husted e Allen (2001).

Dessa forma, em 2011, a estratégia de sustentabilidade foi redesenhada e batizada de Mapa da Sustentabilidade. A Ilustração 9 resume o processo de elaboração do mapa. Entre 2010 e 2011, foram realizadas entrevistas com o presidente do Conselho de Administração, o Presidente Executivo, todos os Vice- Presidentes e diversos diretores. Em 2011, foi feita a análise da visão e do "Nosso Jeito de Fazer", do propósito da marca, das políticas e regulamentos do banco, além dos compromissos voluntários e dos pactos dos quais a empresa 
é signatária. Depois disso, foram feitos cinco workshops com representantes de áreas do banco; apresentação do resultado do trabalho aos diretores para garantir a integração à agenda estratégica dos negócios; validação da proposta da nova estratégia em um novo painel de diálogo com especialistas externos; validação pelo Comitê de Sustentabilidade; validação final pelo Comitê Executivo. (ITAÚ UNIBANCO, 2011)

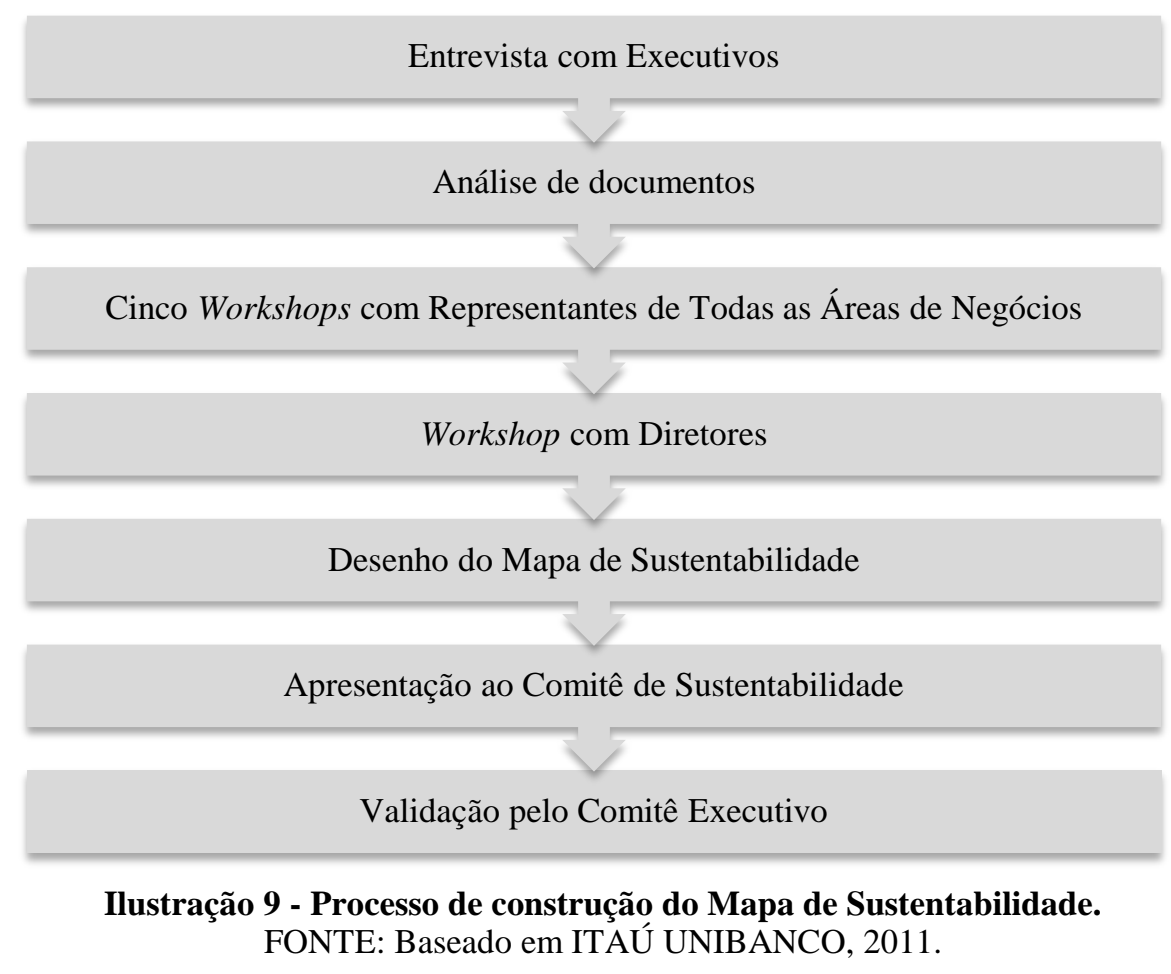

Para a empresa, o Mapa de Sustentabilidade representa a integração da sustentabilidade à sua agenda de negócios. Ele está organizado em três focos estratégicos: Educação Financeira; Riscos e Oportunidades Socioambientais; Diálogo e Transparência. Esses temas representam assuntos significativos para o setor financeiro, no Brasil e em todo o mundo, e são relevantes para a sociedade. São considerados pela empresa temas estratégicos e materiais. (ITAÚ UNIBANCO, 2012)

Dessa forma, a mudança na escolha dos temas prioritários, mostra que a empresa passou a lidar com a RSC a partir de questões ligadas à sua atividade principal, conforme defendido por Porter e Kramer (2006). A Ilustração 10 mostra a mudança no posicionamento da empresa com relação à Sustentabilidade. 


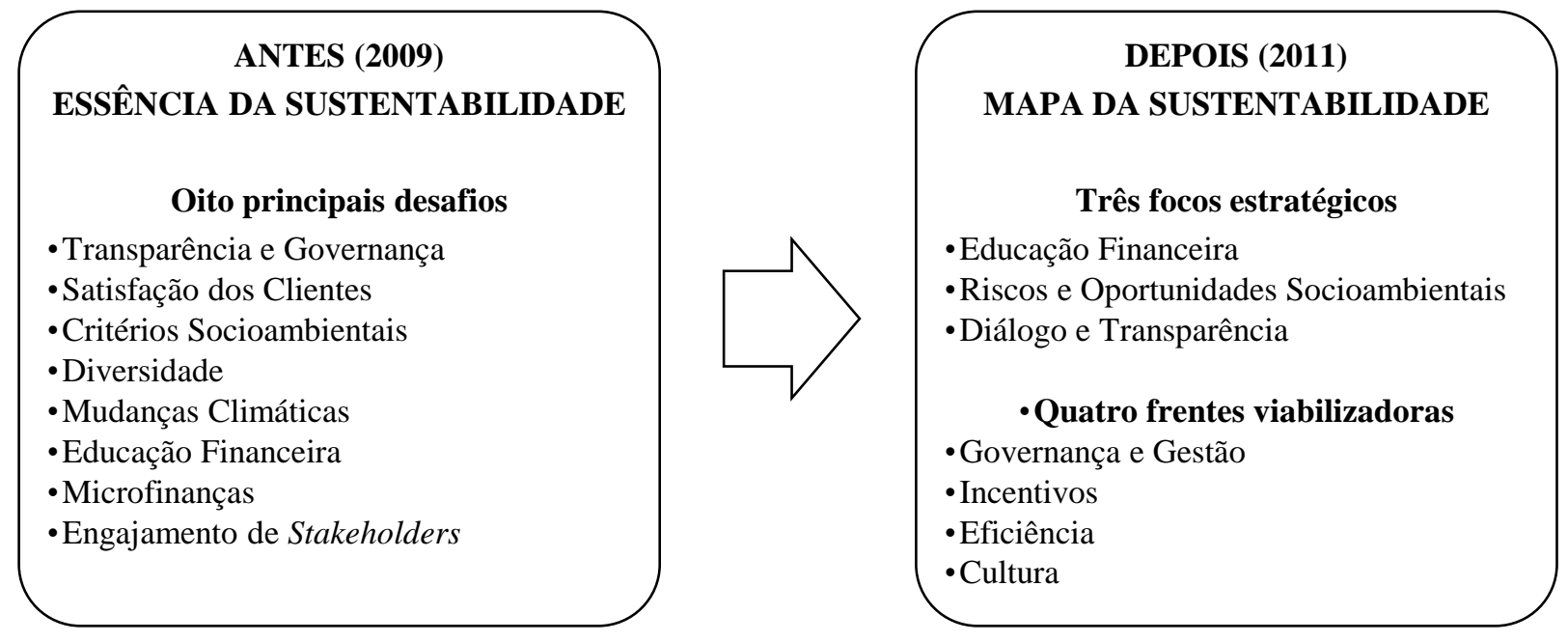

Ilustração 10 - Mudança no posicionamento da empresa com relação à sustentabilidade.

A entrevistada E1 também fala sobre esse processo que começou em 2009.

\begin{abstract}
A fusão levou a empresa a ser um dos dez maiores bancos do mundo na época [...] colocando o banco em um patamar diferente do que era o Itaú e o Unibanco. Para esse novo banco [...] fazer a pergunta se isso (sustentabilidade) era importante foi quase que básico. A partir dessa pergunta, a gente fez um processo que durou mais ou menos um ano e meio [...] Quais eram os desafios? Quais os temas que eu deveria cuidar? O que faz sentido para um banco brasileiro? O que faz sentido para o sistema financeiro? O que faz sentido para um grande banco dentro do sistema financeiro? Basicamente as perguntas são essas [...] Dentro desse processo, o banco discutiu junto com a estratégia, como a sustentabilidade se conectava à agenda de negócios e o que era sustentabilidade para nós.
\end{abstract}

Para a integração e o aprofundamento dos três focos na agenda do banco, também foram estabelecidas quatro frentes viabilizadoras - estruturas internas da organização, transversais a todas as áreas - que funcionam como engrenagens. As frentes viabilizadoras são alavancas internas que dão sustentação às diversas iniciativas desenvolvidas em todas as áreas do banco para que os focos estratégicos estejam sempre conectados às estratégias de negócio. As quatro frentes viabilizadoras são: Governança e Gestão; Incentivos; Eficiência; Cultura. (ITAÚ UNIBANCO, 2012)

Governança e Gestão: Para consolidação da estratégia de gestão da sustentabilidade, foi formada uma governança capaz de inserir o tema em todas as áreas. Por isso, uma nova estrutura de Governança de Sustentabilidade passou a vigorar, em 2012, com maior poder deliberativo. Além disso, a área de Sustentabilidade participa de outras instâncias do banco, como o Comitê de Excelência do Atendimento, o Comitê de Risco Socioambiental e o Comitê de Avaliação de Processos e Produtos. Como resultado da participação nesse último, em 
2012, mais de 200 projetos foram avaliados com a perspectiva dos focos estratégicos da sustentabilidade.

Incentivos: A análise de desempenho e a remuneração variável dos executivos são consideradas pelo banco ferramentas fundamentais para a estratégia da performance sustentável. Alguns exemplos importantes para essa análise são metas que contemplam indicadores financeiros, índice de eficiência, clima organizacional e satisfação de clientes que visam a impulsionar resultados para garantir a performance sustentável dos negócios.

Eficiência: O banco busca a redução de custos e o aumento da geração de receitas, de forma perene, em todas as áreas. Assim, a empresa busca a avaliação sistemática das despesas, a redução de desperdícios, a otimização de recursos, e a melhor sinergia entre as diversas atividades operacionais. Em 2012, foram estabelecidas metas de ecoeficiência para as agências e para os prédios administrativos. Elas objetivam reduzir o consumo de água, energia e papel, diminuir a produção de resíduos e aumentar a capacidade de utilização de energia renovável. Portanto, com melhor utilização dos recursos e com relações de longo prazo mais equilibradas com os clientes, fornecedores e colaboradores, a empresa considera que poderá haver ganhos efetivos na geração de valor para os acionistas e a sociedade.

Cultura: A cultura corporativa é o modo como a empresa busca concretizar sua visão de ser o banco líder em performance sustentável e em satisfação dos clientes. Por isso, o banco afirma que é fundamental que todos os processos de cultura interna estejam alinhados à estratégia de sustentabilidade. Desde 2012, as diretrizes de sustentabilidade estão sendo introduzidas, de forma transversal, em toda a grade de cursos à disposição para a capacitação de colaboradores. Por exemplo, a performance sustentável passou a ser um critério permanente para análise de premiações e reconhecimentos, como no caso do Prêmio Walter Moreira Salles, que reconhece projetos, iniciativas e colaboradores da instituição em diferentes categorias (eficiência, qualidade, inovação e gestão de pessoas).

A entrevistada E3 explica que antes havia uma categoria de sustentabilidade no prêmio, porém, essa categoria foi retirada e a sustentabilidade passou a ser um pré-requisito para todas as outras categorias. A empresa considerou que não havia mais sentido deixar o tema em uma categoria isolada, pois qualquer iniciativa de eficiência, qualidade, inovação e gestão de 
pessoas deveria considerar a sustentabilidade para receber o prêmio.

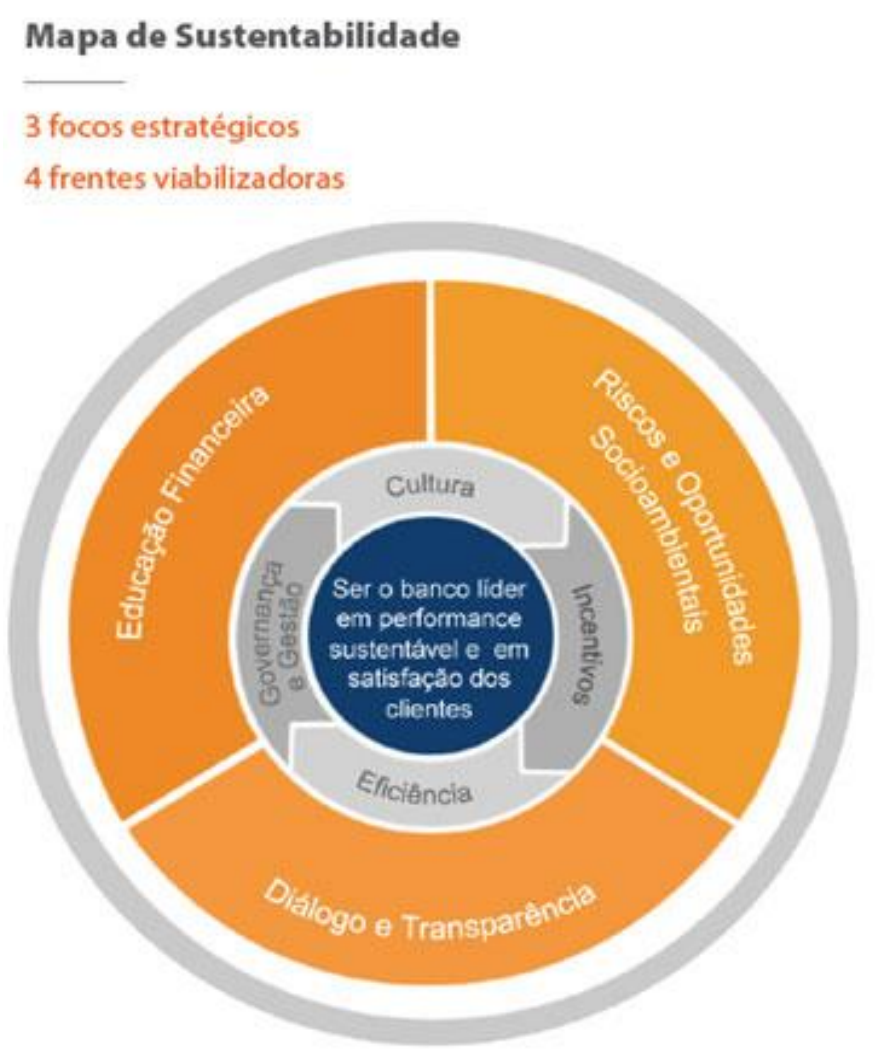

Ilustração 11 - Mapa de Sustentabilidade do Itaú Unibanco. FONTE: ITAÚ UNIBANCO, 2011, p. 37.

A Ilustração 11 é a representação do Mapa de Sustentabilidade. A empresa afirma que o Mapa age como um direcionador estratégico que orienta as diversas áreas operacionais e de negócio a incorporar questões de sustentabilidade em suas tomadas de decisão. Além de criar novos produtos, trabalha para ajustar a atuação, mitigar riscos, encontrar diferenciais competitivos e gerar receita em um contexto de maior demanda para a gestão dos impactos ambientais e sociais. Assim, a empresa acredita que conseguirá alcançar resultados efetivos e de longo prazo. (ITAÚ UNIBANCO, 2012)

A entrevistada E1 afirma que:

A gente tem se detido mais em mexer nas engrenagens de fazer banco, olhando como essas questões conversam com cada uma dessas engrenagens [...] Gerir essas questões [...] dentro do banco como um todo. Isso não é uma responsabilidade da área de Sustentabilidade, mas tem que ser uma responsabilidade das áreas do banco, patrocinada por uma área (de Sustentabilidade). A mudança é executada dentro das próprias áreas, porque são elas que têm que se adaptar. Se não eu crio o banco sustentável aqui na área de Sustentabilidade e o banco continua [...] 
Portanto, a empresa passou a lidar com a RSC de forma estratégica, pois inseriu variável socioambiental ao longo do processo gerencial de planejar, organizar, dirigir e controlar, utilizando-se das áreas funcionais e das interações que ocorrem no mercado, visando a atingir os objetivos e metas organizacionais. (NASCIMENTO et al., 2008) Além disso, o banco reconheceu que a simples inclusão de programas de responsabilidade social não é suficiente para gerar valor à empresa, mas, sim, quando a relação entre RSC e ganho econômico é cuidadosamente desenhada, conforme defendido por Husted e Allen (2001).

\subsubsection{Performance Sustentável}

Durante o processo, também foi definido o conceito de performance sustentável, expresso na visão do banco. Para a empresa, performance sustentável é "gerar valor compartilhado para colaboradores, clientes, acionistas e sociedade, garantindo a perenidade do negócio”. (ITAÚ UNIBANCO, 2012, p. 63). Ela será alcançada a partir de uma série de fatores que atuam de forma interligada, conforme representado na Ilustração 12.

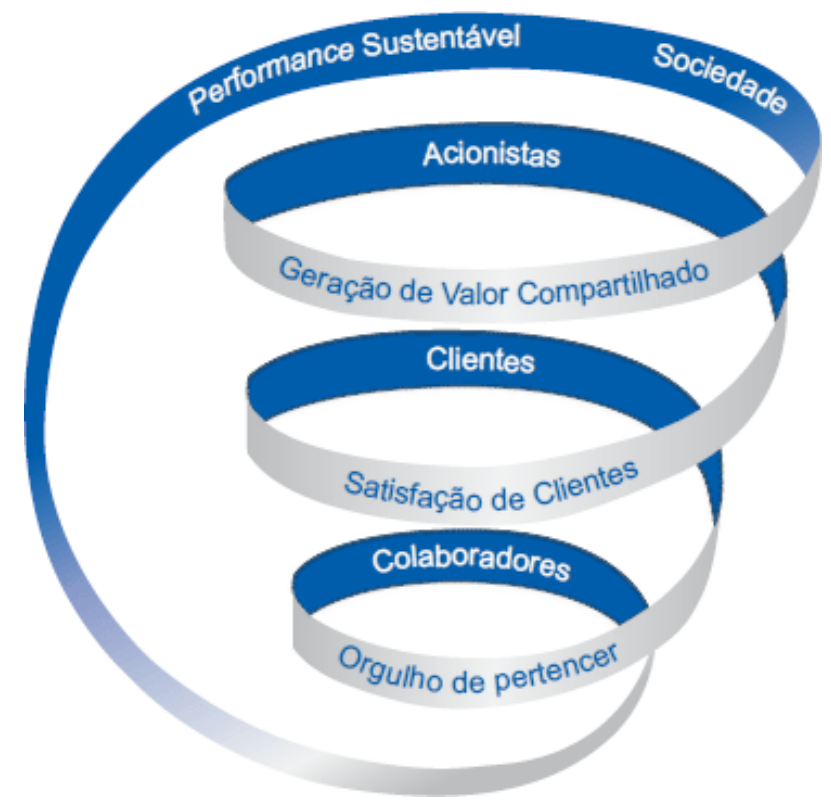

Ilustração 12 - Figura representativa da performance sustentável. FONTE: ITAÚ UNIBANCO, 2012, p. 63.

A figura é explicada pela empresa:

Tudo começa com nossos colaboradores. Ao promovermos o desenvolvimento das pessoas, por meio de uma cultura forte, da prática da meritocracia, de um bom clima organizacional e de incentivos que contemplem a visão do curto ao longo prazo, desenvolvemos, em nossas equipes, o 
orgulho de pertencer. Colaboradores satisfeitos e que se identificam com nossos valores e estratégias atendem melhor aos clientes. Assim, estamos no caminho para atingir a satisfação dos clientes. Promovemos relações equilibradas e de longo prazo, pautadas pela transparência, educação financeira e oferta de soluções adequadas ao ciclo de vida de cada pessoa ou empresa. Além disso, consideramos questões socioambientais no desenvolvimento de novos produtos e serviços e nas análises de riscos. Ao atingirmos a satisfação dos clientes, permanecemos nas escolhas financeiras que eles farão ao longo de suas vidas. Isso gera resultado para nossos acionistas e a manutenção dos negócios no longo prazo. Não basta, contudo, gerar resultado financeiro. Queremos gerar valor compartilhado, com benefícios para todos. É a partir da crença no valor compartilhado que pautamos nossa atuação na sociedade. Queremos ser parceiros no desenvolvimento das pessoas, da sociedade e dos países onde atuamos e, por meio de um diálogo permanente, entender suas expectativas para agir, de maneira ética e responsável, diante dos novos desafios. Com isso, seremos cada vez mais um agente de transformação. (ITAÚ UNIBANCO, 2012)

Essa visão é semelhante à defendida por Clarkson (1995), que afirma que a continuidade da empresa depende de sua habilidade em cumprir com seus objetivos econômicos e sociais, gerando valor para que cada grupo de interesses permaneça nesse sistema. O equilíbrio nas relações com os diferentes grupos é essencial e evita que relações desses grupos com a empresa sejam cortadas.

Quando questionada sobre a forma de divulgar a sustentabilidade entre os milhares de colaboradores, a entrevistada E3 responde que a sustentabilidade para o banco está ligada à performance e fala sobre a espiral da performance sustentável.

A espiral é altamente divulgada no banco [...] O mapa é menos conhecido pela massa toda, ele foi menos divulgado [...] Porque não adianta a gente divulgar muita coisa que pode confundir. O que é mais compreensível é a espiral [...] para o colaborador se enxergar [...] Ela é mais simples. Como tem gente de todos os níveis [...] se for muito complexo, você vai confundir.

Dessa forma, a empresa explicita que busca lidar com a RSC por meio da abordagem do valor compartilhado, ou seja, contribuindo com a sociedade, mas buscando um retorno financeiro. É possível identificar, claramente, que a empresa vem utilizando progressivamente a RSC de forma estratégica. Husted e Salazar (2006) afirmam que o uso estratégico da RSC ocorre quando há claros benefícios para a empresa. Burke e Logsdon (1996) também defendem que a RSC estratégica serve aos interesses econômicos da empresa e aos interesses dos seus stakeholders. 


\subsubsection{Principais Questões de RSC}

As questões de RSC escolhidas como estratégicas para o banco são as indicadas como Focos Estratégicos do Mapa de Sustentabilidade, as quais são: Educação Financeira; Riscos e Oportunidades Socioambientais; Diálogo e Transparência.

A entrevistada E1 destaca a importancia das escolhas e afirma que existe, por parte da empresa, um comprometimento e uma capacidade de avaliar se o que está sendo feito e proposto é adequado ou esperado.

Se, por exemplo, amanhã eu resolver que o melhor projeto é salvar as baleias do Ártico. Faz sentido? É ótimo para o planeta e até para as baleias, mas não tem nenhum sentido para mim. Então, ser coerente com aquilo que você faz no dia a dia é uma das variáveis importantes [...] A sabedoria está em escolher, se não você gasta um monte de recursos e não muda nada. Então estratégia é fundamental. É por isso que a gente operou no estratégico. (E1)

O discurso da entrevistada revela a preocupação em não fazer contribuições sociais e ambientais que apenas reflitam crenças e valores pessoais dos gestores, mas que estejam vinculadas a objetivos bem formulados e alinhados à Estratégia, conforme defendido por Porter e Kramer (2006).

\subsubsection{Educação Financeira}

O termo crédito responsável se refere às práticas das atividades de empréstimo e financiamento que atuam de forma a melhorar a situação financeira do cliente, ao invés de prejudicá-la. Assim, o crédito responsável envolve o empréstimo de quantias apropriadas, com taxas de juros e prazos em condições razoáveis, garantindo que os clientes não comprometam grande parcela de sua renda com um financiamento que, em determinado momento, possa não ser honrado. Além disso, esta prática envolve o aconselhamento financeiro do tomador, para que ele não se exponha a riscos financeiros desnecessários e inapropriados, considerando seus objetivos de curto e longo prazos. (FBDS, 2007)

O crédito responsável traz dois principais benefícios para os bancos. Primeiramente, um cliente muito endividado, hoje, pode deixar de ser cliente amanhã, enquanto um cliente tomador de empréstimos menores e mais alinhados com seu nível de renda tenderá a 
continuar gerando negócios para os bancos. Além disso, o crédito responsável também traz ganhos intangíveis para a empresa, à medida que fortalece a confiança do cliente na instituição, melhorando por consequência a sua marca e reputação. (FBDS, 2007)

O banco declara que a educação financeira é considerada um assunto estratégico, pois o desequilíbrio nas finanças pessoais pode comprometer a capacidade de pagamento, prejudicando os cidadãos, as empresas e o país. Com o endividamento as pessoas deixarão de consumir, as indústrias desacelerarão suas atividades, deixarão de gerar empregos e pagar impostos. O mesmo vale para os empreendimentos de pequeno porte, que sem uma boa gestão orçamentária, não terão recursos para investir em novas frentes de mercado, limitando seu crescimento. A iniciativa de educação financeira foi chamada pelo banco de Uso Consciente do Dinheiro. (ITAÚ UNIBANCO, 2012)

Essa lógica apresentada pela empresa se refere à preocupação com seu contexto competitivo. Segundo Porter e Kramer (2006), existe uma interdependência entre a empresa e a sociedade, que surge tanto de dentro para fora quanto de fora para dentro. Ou seja, as condições externas exercem influência sobre os resultados da empresa e, assim, ações de RSC podem ser usadas para melhorar a qualidade do ambiente de negócios em que a empresa opera.

A entrevistada E3 fala sobre o preconceito de que os bancos ganham dinheiro, quando os clientes atrasam seus pagamentos:

Banco tem um papel fundamental como alavancador econômico da sociedade. Eu acho que existe um preconceito e um tabu, uma imagem negativa de que [...] o lucro do banco é com base em atraso e com base no endividamento dos clientes, mas muito pelo contrário. $\mathrm{O}$ banco ganha mais dinheiro quando tudo está indo bem, [...] quando você tem dinheiro sobrando e pode investir [...] e quando você quer crescer e você precisa de um capital que te ajude a crescer, que seriam os empréstimos. É aí que o banco ganha, e não com atrasos.

Seguindo essa lógica, o banco afirma que trabalha esse tema por meio da orientação de colaboradores, clientes e demais públicos a fazer um bom uso dos produtos financeiros. Isso é feito por meio da educação, comunicação e de ferramentas como simuladores, que auxiliam no planejamento. (ITAÚ UNIBANCO, 2012)

O programa para colaboradores engloba hotsite na intranet, chats, matérias e artigos nos diferentes canais internos de comunicação, palestras, campanhas de engajamento e 
treinamentos. Para os clientes e demais públicos, a empresa criou guias que abordam diferentes situações e momentos de vida das pessoas, além de cartilhas sobre o uso consciente do crédito para empresas. Há também palestras sobre educação financeira para clientes empresariais e voluntários da Fundação Itaú Social e do Instituto Unibanco. Um exemplo de ferramenta oferecida aos clientes é um orientador de crédito, disponível no site da empresa, para auxiliar os clientes na escolha do crédito mais adequado à sua realidade e necessidade. No segmento empresas, um exemplo é uma consultoria financeira, tecnológica e de gestão socioambiental para pequenas e médias empresas selecionadas. Outro exemplo é o Programa Consultoria Sustentável, oferecido em parceria com o Serviço Brasileiro de Apoio às Micro e Pequenas Empresa (SEBRAE). O programa inclui curso a distância, materiais e consultoria de especialistas para a realização de diagnóstico da empresa, reorganização financeira e retomada do crescimento. (ITAÚ UNIBANCO, 2012)

No entanto, apesar dos potenciais benefícios, a questão do crédito responsável é um pouco mais complexa, devido ao problema do conflito de interesses existente entre as diversas partes envolvidas. De um lado, gerentes comerciais têm que atingir metas muitas vezes arrojadas, utilizadas em sistemas de avaliação de desempenho focados em resultados. Do outro estão os clientes, com limitado entendimento dos produtos financeiros disponíveis. A equação se torna ainda mais complicada com a atuação predatória de competidores, pressionando a instituição a atingir melhores resultados. Assim, como atuar de forma responsável, garantindo a saúde financeira de longo prazo dos clientes, sem efetivamente prejudicar os resultados da instituição? (FBDS, 2007)

A entrevistada E1 argumenta que, quanto melhor a capacidade do cliente de escolher o crédito e a do banco de acertar o crédito, melhor será a eficiência do banco no médio e longo prazos. O cliente poderá usar o crédito muito mais vezes, o banco poderá vender mais produtos e, além disso, irá sempre receber. Com isso, os juros poderão ser baixados e cria-se um círculo virtuoso. A entrevistada afirma que esse é o único jeito de permanecer na liderança, porque se o banco quebrar o próprio mercado, suas operações futuras ficarão comprometidas.

Portanto, lidar com a questão do crédito responsável não é um desafio simples. Além de investimentos em sistemas que possibilitem o entendimento completo da situação financeira dos clientes, os sistemas de avaliação de performance dos bancos deveriam ser revistos para estimular o comportamento responsável de gerentes, ao mesmo tempo que não prejudiquem a 
criação de valor para o banco. Além disso, seria importante conscientizar os agentes com maior relacionamento com o público, de forma a orientá-los quanto ao valor de uma ação sustentável no momento do aconselhamento do cliente menos informado. (FBDS, 2007)

\subsubsection{Riscos e Oportunidades Socioambientais}

As instituições financeiras podem diminuir o risco de crédito e a inadimplência de sua carteira de clientes, além de assegurar que o valor das garantias dadas pelos mesmos não se altere consideravelmente, ao avaliar os riscos socioambientais na decisão de concessão do crédito. Por exemplo, no crédito para empresas do setor de petróleo, uma empresa que possui alto risco de derramamento de óleo possivelmente terá que lidar com passivos ambientais, que influenciem sua capacidade de honrar o compromisso de crédito. Ao identificar esse risco, a instituição financeira pode exigir que a empresa cliente tenha um plano para gerenciá-lo, e caso ela não tenha, o financiamento poderia em última análise ser negado. Da mesma forma, uma empresa do setor sucroalcooleiro que utiliza mão de obra escrava, possivelmente, será alvo de processos trabalhistas que poderão em algum momento influenciar a sua geração de caixa. (FBDS, 2007)

A entrevistada E1 aborda essa lógica:

É visível que não existe um jeito de não olhar essas questões (socioambientais), porque se você está financiando um posto de gasolina, por exemplo, e ele tiver uma multa porque contaminou o solo [...] ele vai parar de pagar o empréstimo, não por uma questão ambiental, mas porque ele foi multado. A atividade foi interrompida e, portanto, ele não gera mais caixa. É um problema financeiro que começou por um problema ambiental.

Além da diminuição de riscos, as empresas podem identificar oportunidades para o desenvolvimento de novos produtos e serviços, em áreas relacionadas com a responsabilidade socioambiental. Por exemplo, financiamentos ligados a projetos de redução de resíduos sólidos ou emissão de efluentes, troca de combústivel líquido por gás natural, financiamentos para aquisição de veículos para pessoas com deficiência e financiamentos para o plantio de eucalipto para pequenos produtores rurais. 


\subsection{Crédito}

Desde dezembro de 2007, a empresa adota critérios socioambientais na análise de operações de crédito acima de $\mathrm{R} \$ 5$ milhões, para os clientes pessoas jurídicas do conglomerado Brasil. A empresa tem uma Política de Risco Socioambiental corporativa, que formaliza os critérios socioambientais adotados no processo de crédito para empresas. Para analisar e liberar recursos, além dos aspectos convencionais, como finanças, gestão e governança, são observadas as práticas das companhias com relação aos direitos humanos, meio ambiente e biodiversidade, entre outros. Alguns exemplos de quesitos avaliados são: utilização de mão de obra infantil de forma prejudicial e/ou exploratória; empresas incluídas no cadastro de empregadores que tenham mantido trabalhadores em condições análogas à de escravo e questionário de autodeclaração socioambiental, respondido pelas empresas. Além disso, nas operações de project finance acima de US\$ 10 milhões, a empresa segue os Princípios do Equador. (ITAÚ UNIBANCO, 2008, 2012)

Um fator importante, relacionado ao financiamento de atividades controversas e setores com possibilidade de gerar externalidades socioambientais negativas, é a existência ou não de uma política socioambiental específica para cada setor. Em geral, o que se observa entre os maiores bancos brasileiros é que, mesmo possuindo uma exposição considerável da carteira de crédito para determinados setores, essas instituições financeiras nem sempre possuem políticas setoriais específicas, que determinem sob que condições e para que tipos de projetos e empreendimentos o crédito pode ser liberado. (BANKTRACK; AMIGOS DA TERRA, 2012)

A empresa criou abordagens específicas para determinados setores. Um exemplo é o programa de sustentabilidade no crédito imobiliário, em que a aprovação de financiamentos a empreendimentos está condicionada a boas práticas em questões, como proteção do solo e de mananciais e obtenção de licenças ambientais. Há também linhas de financiamentos específicas, por exemplo, para apoio à agricultura de baixo carbono ou para financiar projetos, bens e serviços com foco na sustentabilidade. (ITAÚ UNIBANCO, 2012)

Apesar de o banco utilizar abordagens específicas por setor, a entrevistada E1 levanta uma das dificuldades enfrentadas, na inclusão de critérios socioambientais, na política de crédito imobiliário. 
Todas as áreas contaminadas da cidade de Sao Paulo ou do Brasil estão mapeadas? Não. Sou eu que tenho que mapear? Não. É a CETESB. Como é que eu posso falar: Eu não aceito um terreno contaminado como garantia ou não financio um projeto num lugar desse. Eu não financio, mas se eu não tiver como checar como é que eu faço? [...] Vale ignorar o fato? Não, não tem como. E tendo consciência do fato está tudo resolvido? Não, porque ainda tem que trabalhar no "como".

A empresa considera documentos e informações socioambientais, além de realizar visitas para verificação no local e consultas a informações públicas. Para os processos referentes à aplicação da Política de Riscos e dos Princípios do Equador, são realizadas auditorias. O Quadro 16 mostra a categorização da análise da capacidade de gestão socioambiental das empresas a serem financiadas pelo banco.

Quadro 16 - Categorização da análise socioambiental.

\begin{tabular}{|c|c|c|}
\hline A- & $\begin{array}{c}\text { Alto potencial de impacto socioambiental significativo } \\
\text { Baixa capacidade de gerenciamento de riscos socioambientais }\end{array}$ & Alto \\
\hline B- & $\begin{array}{c}\text { Médio potencial de impacto socioambiental significativo } \\
\text { Baixa capacidade de gerenciamento de riscos socioambientais }\end{array}$ & Alto \\
\hline A+ & $\begin{array}{c}\text { Alto potencial de impacto socioambiental significativo } \\
\text { Empresa com capacidade de gerenciamento de riscos socioambientais }\end{array}$ & Médio \\
\hline B+ & $\begin{array}{r}\text { Médio potencial de impacto socioambiental significativo } \\
\text { Empresa com capacidade de gerenciamento de riscos socioambientais }\end{array}$ & Baixo \\
\hline C & Baixo potencial de impacto socioambiental significativo & Baixo \\
\hline
\end{tabular}
FONTE: ITAÚ UNIBANCO, 2008.

A entrevistada (E1) explica que a discussão sobre a inclusão de critérios socioambientais na análise de concessão de crédito começou com os Princípios do Equador, que abrangia os grandes projetos. Mais tarde, foram desenvolvidas metodologias para aplicar critérios socioambientais para crédito a empresas menores. Porém, a grande limitação é que não há um sistema em que informações sobre problemas sociais e ambientais das empresas possam ser consultadas. Diante disso, a empresa tem duas opções, uma seria enviar um fiscal para analisar cada um dos clientes - o que é inviável - e a outra enviar um questionário autodeclaratório para as empresas - o que acontece atualmente.

A entrevistada E1 ainda afirma que, algumas vezes uma empresa pode declarar que não possui determinada conduta ou que realizará determinadas ações, como tirar uma licença ambiental, e pode acabar não cumprindo. Porém, não é papel do banco fiscalizar. O que ocorre é que o banco se preocupa em olhar essas questões, tanto por questões de risco de crédito, quanto por questões de risco de imagem. 


\subsection{Investimentos}

Em 2008, a empresa aderiu ao PRI, criado por investidores institucionais com o objetivo de promover a integração de critérios sociais, ambientais e de governança corporativa, na tomada de decisão de investimentos.

Alianhado com os Princípios, o banco desenvolveu uma metodologia para mapear aspectos que possam influenciar o valor de mercado das empresas nas quais investe. Há critérios específicos para cada setor, por exemplo, é analisada a escassez de recursos naturais importantes para determinada empresa ou a situação de sua cadeia de fornecedores. (ITAÚ UNIBANCO, 2012)

Há também um portfolio de fundos que direcionam os investimentos para ações de empresas com boas práticas ambientais, sociais e de governança corporativa. Por exemplo, há um fundo, criado em 2004, que aplica recursos em ações de empresas com reconhecidas práticas sociais, ambientais e de governança corporativa, e que destina 50\% de sua taxa de administração às ONGs ligadas à área da educação. A empresa também foi responsável pelo lançamento do primeiro fundo de estratégia protegida, vinculado a um índice de créditos de carbono, o Barclays Capital Global Carbon Index (BCGI). Outro exemplo são fundos lançados, em 2007, que revertem 30\% da taxa de administração para o apoio a projetos que reduzem a emissão de GEE - principal fator responsável pelo aquecimento global. (ITAÚ UNIBANCO, 2012)

O primeiro fundo de ações de empresas consideradas socialmente responsáveis da América Latina foi o Ethical, do Banco Real. Criado em 2001, o fundo apresentou de novembro de 2001 a maio de 2008, uma rentabilidade acumulada de 578,2\% contra 490,6\% da valorização do IBOVESPA. Hoje há fundos do mesmo tipo, em outras instituições bancárias, como Bradesco, HSBC e outros.

\subsection{Seguros}

Em junho de 2012, a UNEP-FI lançou no Rio de Janeiro, em evento paralelo a Rio+20, os 
Princípios para Sustentabilidade em Seguros, elaborados a partir de pesquisas mundiais concentradas nos riscos e nas oportunidades em seguros, associados às questões ambientais, sociais e de governança. Na ocasião, 107 seguradoras de 92 diferentes países assinaram documento comprometendo-se a assumir os Princípios, entre elas o Itaú Unibanco. (UNEP-FI, 2012)

A empresa incorpora os Princípios em seus processos e produtos de seguros, agregando serviços ambientais às coberturas convencionais, oferecidas pelo seguro residencial. $\mathrm{O}$ produto passou a oferecer informações sobre boas práticas ambientais dentro de casa, serviço de retirada e destinação de objetos descartados (equipamentos eletroeletrônicos, móveis e outros) e orientação para a realização de projetos de construção e reforma para tornar a casa mais sustentável. A empresa foi pioneira nessa área, com o Seguro Ambiental, lançado em 2005, que oferece proteção de responsabilidade civil por danos de poluição ambiental. (ITAÚ UNIBANCO, 2012)

\subsubsection{Diálogo e Transparência}

Transparência nos mercados financeiros é uma das maiores demandas representadas pelas organizações sociais que monitoram a ação dos bancos. Organizações sociais como Banktrack, Bank Information Center e Bretton Woods Projects manifestaram fortes críticas à falta de transparência dos bancos, logo após os primeiros impactos da crise financeira de 2008. (MAGALHÃES, 2010)

A transparência das operações financeiras se refere à possibilidade de mapear as conexões pelas quais fluem os recursos financeiros e é importante porque é uma condição para o próprio funcionamento dos mercados, uma vez que permite aos agentes financeiros avaliar e gerenciar de forma mais precisa os riscos e potenciais retornos das operações financeiras. Além disso, é uma necessidade para o conjunto da sociedade, preocupada com os impactos das atividades financeiras sobre o conjunto das economias e suas consequências, principalmente, sobre a produção de emprego e, mais recentemente, sobre o meio ambiente e a qualidade de vida das pessoas. (MAGALHÃES, 2010)

O banco declara em seu Relatório Anual de Sustentabilidade que a perenidade dos seus 
negócios depende da maneira como é feita a interação com seus colaboradores, clientes, acionistas e a sociedade. Para construir relações de longo prazo entre a empresa e esses públicos, e trazer resultados para todos os envolvidos, é necessário ouvir e entender suas demandas e comunicar os compromissos e resultados dos negócios, com clareza e transparência. (ITAÚ UNIBANCO, 2012)

A empresa possui uma pesquisa anual de clima em que os colaboradores podem opinar e comentar, abertamente, temas vinculados às práticas de gestão do banco, sendo assegurado o sigilo e a confidencialidade de seus dados. Ao final da pesquisa, os resultados são consolidados por área e discutidos em grupos de trabalho, dando origem a planos de ação para os pontos que precisam ser aprimorados. (ITAÚ UNIBANCO, 2012)

Com relação aos clientes, os contratos do banco passaram a ter uma linguagem mais acessível. Além disso, a empresa afirma que substituiu os termos técnicos em extratos e faturas e passou a exibir alertas, no caixa eletrônico e na internet, sempre que o cliente for usar o cheque especial, além de enviar alertas sobre movimentações no cartão de crédito.

Para o diálogo e transparência com os acionistas e investidores, o banco publica seu Relatório Anual de Sustentabilidade, em linha com as diretrizes da GRI, e vincula seu desempenho econômico, social e ambiental aos princípios do Pacto Global, da ONU. Há também reuniões públicas em parceria com a Associação dos Analistas e Profissionais de Investimento do Mercado de Capitais (APIMEC), e rodadas de visitas no exterior, para apresentar os resultados a investidores estrangeiros. Em 2011 foi lançado, também, um encontro anual que reúne investidores institucionais.

Com relação à sociedade, a empresa lançou canais de diálogo com diferentes segmentos, buscando levar para dentro do banco a compreensão sobre demandas externas. A empresa tem utilizado as redes sociais para compartilhar informações institucionais, orientar sobre o uso consciente do dinheiro e ouvir o que os clientes e a sociedade têm a dizer. Há também workshops com fornecedores e um canal exclusivo de relacionamento com esse público.

Outro exemplo de diálogo com stakeholders são os Diálogos de Sustentabilidade, que ocorrem desde 2006, em que especialistas são convidados para discutir assuntos do momento 
com colaboradores, fornecedores e outros públicos. Trimestralmente, jornalistas e formadores de opinião são convidados para participar dos encontros Sustentabilidade em Pauta, em que especialistas debatem diferentes questões sobre o tema.

Dessa forma, os temas definidos como estratégicos, atualmente, para o banco são Educação Financeira; Riscos e Oportunidades Socioambientais; Diálogo e Transparência. Porém, a entrevistada E1 explica que essa escolha pode mudar com o tempo, pois as variáveis que afetam o negócio são muito dinâmicas e precisam estar sendo sempre revistas. Os gestores estão, constantemente, questionando qual é o melhor jeito de utilizar os recursos disponíveis e de influenciar para uma mudança. As respostas para esses questionamentos não duram por um prazo longo. Por isso, a questão principal é a atuação na gestão da empresa e não buscar uma política definitiva do que deve ser feito. A entrevistada afirma que para se manter na liderança é preciso estar preparado para ler as mudanças e interagir com elas e não reagir a elas.

Na escala de Clarkson (1995) de DSC, a postura reativa - que nega a responsabilidade - é o nível mais baixo das estratégias de RSC e a postura proativa - que antecipa a responsabilidade e faz mais do que é requerido - é o nível mais alto. É possível, assim, identificar que a empresa se encontra no nível mais alto de DSC e busca antecipar as necessidades dos stakeholders, o que está diretamente ligado à preocupação em manter seus negócios e sua liderança no longo prazo.

Contudo, é importante destacar que as entrevistadas levantaram algumas barreiras para a incorporação da RSC nas atividades da empresa. A entrevistada E1 acredita que a falta de ferramentas e de conhecimento são as principais dificuldades. Outra barreira levantada é o problema de escala. Não há um sistema com informações padronizadas e, legalmente reconhecidas, de possíveis irregularidades socioambientais dos clientes que possa ser consultado em grande escala. Essa falta de informações acaba exigindo um grande volume de verificações, o que não é viável para uma empresa com milhões de clientes.

A entrevistada E2 também levanta essa questão:

Não tem ferramenta pronta no mercado, por exemplo, com relação à avaliação do risco socioambiental [...] E a métrica por trás disso? Como é que eu avalio isso? Não tem no mercado. Você não compra em uma consultoria. Não existe consultoria que tenha isso. Não existe um sistema que você compra, acopla e sai fazendo. Você tem que treinar as pessoas, porque ninguém 
foi treinado para isso. Você tem que desenvolver a métrica, testar a métrica para ver se funciona. Tudo tem que ser feito. Então o "como” é um aprendizado.

As dificuldades levantadas coincidem com resultados encontrados pela pesquisa Sustainability Survey of Financial Institutions, apresentada anteriormente, em que $86 \%$ dos bancos comerciais afirmaram que gostariam de receber mais assistência em questões de sustentabilidade. Destacaram que precisam de meios para melhorar o conhecimento sobre sustentabilidade, informações, assistência técnica e serviços de consultoria sobre o tema.

\subsubsection{Governança Corporativa}

A estrutura de Governança Corporativa da empresa é responsável por definir estratégias, tomar decisões e monitorar o relacionamento do banco com seus acionistas, colaboradores e diversos públicos. A empresa declara que o principal objetivo da governança é alcançar a excelência no relacionamento entre a companhia, o conselho de administração, os comitês a ele relacionados, os acionistas e o mercado. A empresa aderiu ao código de autorregulação e boas práticas das companhias abertas da Associação Brasileira de Companhias Abertas (ABRASCA). A iniciativa estabelece princípios, regras e recomendações para as melhores práticas de governança corporativa. (ITAÚ UNIBANCO, 2012)

A estrutura de governança compreende:

Assembleia Geral: órgão soberano do banco que congrega os acionistas e que se reúne, ordinariamente, no primeiro quadrimestre de cada ano.

Conselho de Administração: eleito pela assembleia dos acionistas, reúne-se mensalmente, e a ele compete definir a estratégia geral de atuação do banco e das empresas controladas. No exercício de 2012, o Conselho contava com 12 membros, sendo quatro independentes (33\%).

O conselho de administração é avaliado anualmente para assegurar que seus membros estejam alinhados com os valores da organização e congreguem os interesses dos acionistas, dos gestores e dos colaboradores, bem como os temas pertinentes às responsabilidades social e ambiental. (ITAÚ UNIBANCO, 2012, p. 40)

Comitês: a administração conta com seis comitês, que se reportam diretamente ao Conselho 
de Administração. Eles são compostos por, no mínimo, três e, no máximo, dez membros com exceção do comitê de auditoria, cujo número máximo é de sete membros. Todos os integrantes dos Comitês têm mandato de um ano. Os Comitês que atuam atualmente são: Comitê de Auditoria, Comitê de Estratégia, Comitê de Gestão de Riscos e de Capital, Comitê de nomeação e Governança Corporativa, Comitê de Pessoas, Comitê de Remuneração.

No Relatatório Anual de Sustentabilidade (2012), a empresa declara que, no primeiro bimestre de 2013, seria criado o Comitê de Partes Relacionadas, composto por três membros dois independentes do Conselho de Administração e um membro do Comitê de Auditoria. Esse comitê tem como função analisar as transações entre partes relacionadas, assegurando a igualdade e a transparência, de modo que garanta aos acionistas, aos investidores e a outras partes interessadas que o banco se encontra de acordo com as melhores práticas de governança corporativa. Porém, de acordo com a entrevistada E2, esse comitê ainda não foi implementado.

Conselho Fiscal: órgão independente da administração responsável por supervisionar as atividades da administração e dos auditores independentes. É composto por no mínimo três e no máximo cinco membros eleitos em assembleia geral. Entre as responsabilidades do Conselho Fiscal está a elaboração de parecer técnico sobre os relatórios trimestrais e anuais, submetidos à aprovação dos acionistas.

Diretoria: é o órgão responsável pela administração e execução das diretrizes estabelecidas pelo Conselho de Administração. Seus membros são eleitos pelos conselheiros e têm mandato de um ano. Em 2012, a diretoria era composta por 15 membros.

Comitê de Divulgação e Negociação: criado em 2002, a atuação do comitê abrange ações internas que buscam melhorar o fluxo de informações e zelar pela conduta ética de administradores e colaboradores, assegurando transparência, qualidade, igualdade e segurança nas informações prestadas aos acionistas, investidores e demais agentes do mercado de capitais. O comitê reúne-se, trimestralmente, sempre que convocado pelo diretor de Relações com Investidores - membro permanente do órgão. Os outros membros, no mínimo dois e no máximo dez, são escolhidos, anualmente, e devem ser integrantes do Conselho de Administração, da Diretoria da companhia e de companhias controladas e entre profissionais com conhecimento na área de mercado de capitais. 


\subsubsection{Política de Sustentabilidade}

A Política de Sustentabilidade tem o objetivo declarado divulgar para clientes, acionistas, colaboradores, fornecedores, formadores de opinião e sociedade em geral, a intensão da empresa de que os conceitos de sustentabilidade saiam do papel e sejam cada vez mais incorporados ao cotidiano.

A Política de Sustentabilidade, publicada em 2012, tem como objetivos: a) ratificar o compromisso com a busca pelo desenvolvimento sustentável; b) evidenciar as diretrizes que permeiam a estratégia e a gestão junto a todas as partes interessadas; c) promover inovações, revisões e adequações nos negócios com base nos conceitos de sustentabilidade.

A Política de Sustentabilidade estabelece as premissas, a governança para a Sustentabilidade e as diretrizes, e define os compromissos e a prestação de contas. A Política de Sustentabilidade estabelece diretrizes sobre: gestão; produtos e serviços; público interno; relações com fornecedores, clientes, sociedade e meio ambiente.

O Quadro 17 traz um resumo, em ordem cronológica, da evolução das práticas de governança da empresa. 
Quadro 17 - Histórico das práticas de governança.

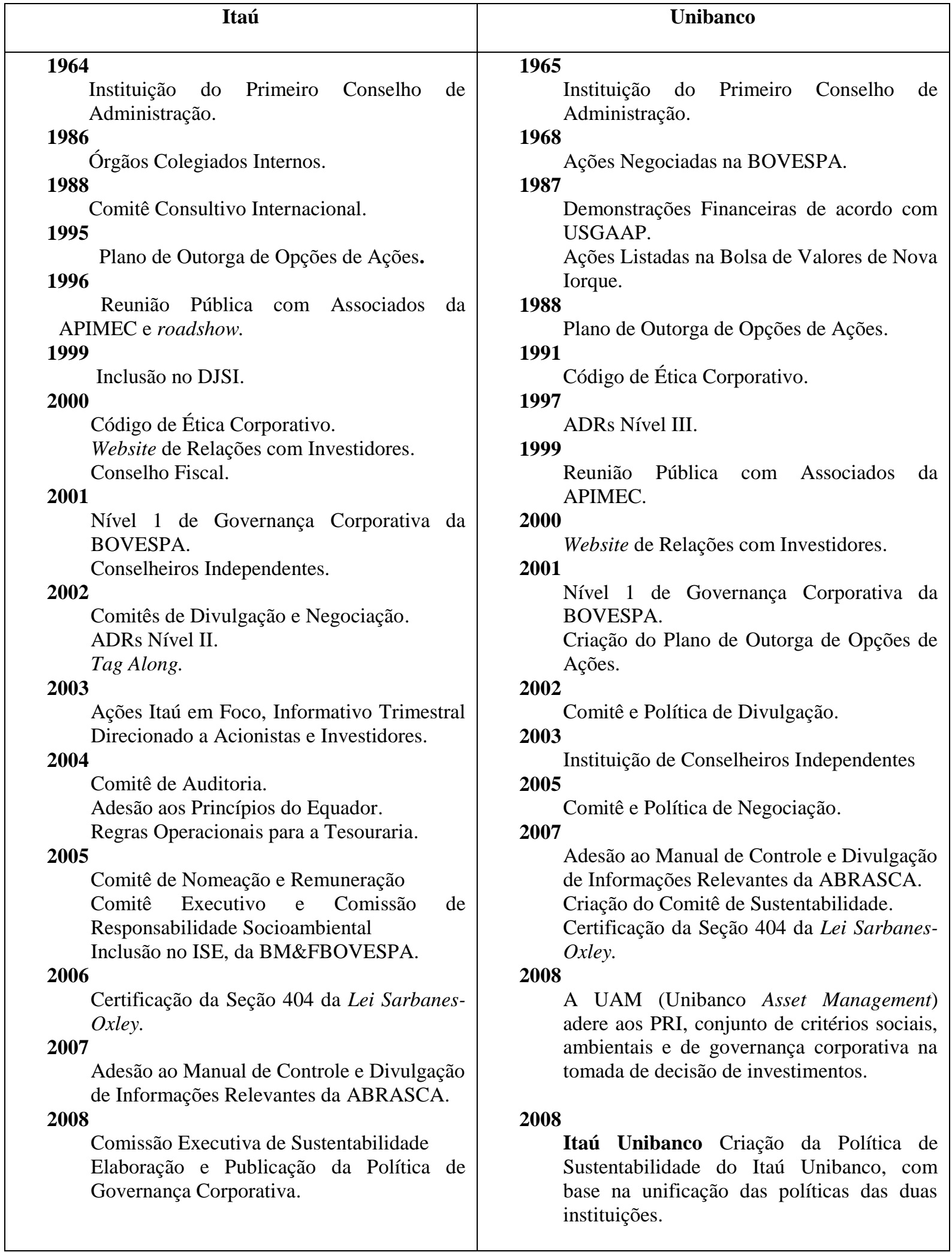

FONTE: ITAÚ UNIBANCO, 2008. 


\subsubsection{Governança de Sustentabilidade}

A Governança de Sustentabilidade do banco tem como objetivo fortalecer a agenda de sustentabilidade nos processos de decisão, alinhando-os aos temas estratégicos que foram definidos. Em 2012, um novo modelo de governança da sustentabilidade da organização entrou em vigor. Uma evolução foi a criação de quatro Grupos de Gestão temáticos multiárea: Educação Financeira; Riscos e Oportunidades Socioambientais; Diálogo e Transparência; Compromissos Voluntários. A estrutura engloba três comitês integrados por executivos, além de grupos temáticos. (ITAÚ UNIBANCO, 2012)

As instâncias da Governança de Sustentabilidade são:

Comitê de Supervisão de Sustentabilidade - composto por membros do Conselho de Administração, reúne-se, anualmente, fornece subsídios às estratégias de longo prazo e tem a responsabilidade de acompanhar e orientar a Política de Sustentabilidade, assim como validar a estratégia de longo prazo da empresa com relação à sustentabilidade. O primeiro encontro, previsto para o fim de 2012, foi realizado em janeiro de 2013.

Comitê Executivo de Sustentabilidade - responsável pela integração entre as estratégias de negócio e a sustentabilidade e pela promoção da corresponsabilidade das diversas áreas da organização, na integração da sustentabilidade à gestão e à cultura organizacional. É composto por membros do Comitê Executivo (Vice-Presidentes e Diretores Executivos). As reuniões são realizadas, semestralmente, e podem ocorrer, extraordinariamente, quando necessário. Em 2012, foram realizados três encontros.

Comitê de Sustentabilidade - implementa a estratégia de sustentabilidade e assegura a sua gestão, além de monitorar a evolução dos planos de ação, o desenvolvimento de indicadores e a mensuração de metas. Possui caráter deliberativo e é composto por Diretores e Superintendentes de áreas envolvidas na implementação de iniciativas, relacionadas à estratégia de sustentabilidade. Foram realizadas oito reuniões, gerais e temáticas, nas quais foi possível reforçar os objetivos de cada foco estratégico.

Grupos Temáticos - são formados para gerenciar as iniciativas em andamento, alinhar e compartilhar o conhecimento. Seus focos de trabalho são: Educação Financeira, Riscos e 
Oportunidades Socioambientais e Diálogo e Transparência. Há também um grupo de trabalho de compromissos voluntários, formado pelas áreas de Compliance, Jurídico, Controles Internos, Relações Governamentais e Sustentabilidade, que têm por finalidade gerenciar o fluxo de aprovação de novos compromissos, avaliar a aderência a eles e tratar de planos de ação para eventuais lacunas e descolamentos.

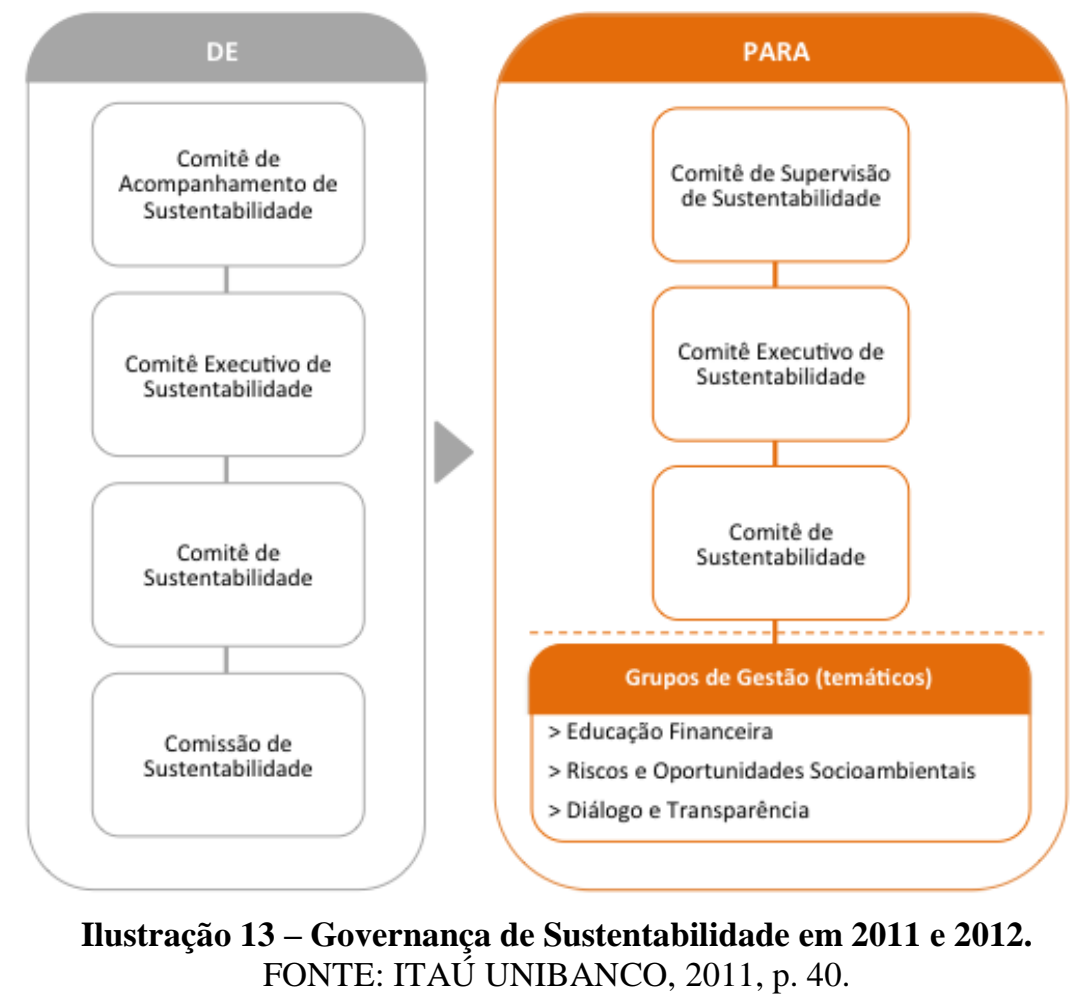

A entrevistada E2 explica que a principal diferença entre a Governança de Sustentabilidade, que passou a vigorar em 2012 e a anterior, foi a criação dos grupos temáticos, conforme mostrado na Ilustração 13. Antes havia uma grande comissão composta por pessoas de todo o banco que discutia todas as questões de sustentabilidade. Então, por exemplo, quem era de Recursos Humanos participava de discussões sobre produto ambiental, que não tinha nenhuma relação com seu trabalho. Com a nova Governança, as questões passaram a ser discutidas por grupos organizados em temas. Dessa forma, as pessoas discutem seus temas de interesse dentro do grupo que abordará aquele assunto.

Além de ter sua própria governança, a área de Sustentabilidade participa de outras governanças do Banco, como o Comitê de Excelência do Atendimento, o Comitê de Risco Socioambiental e o Comitê de Avaliação de Processos e Produtos. A entrevistada E1 resume: 
A participação na governança do banco, a definição dos temas e o norte estratégico, que a gente chama de performance sustentável, são os componentes que fazem com que o tema seja discutido por toda a organização. Isso é chave em uma organização de 100.000 pessoas e 40 milhoes de clientes.

\subsubsection{Avaliação dos Resultados Obtidos}

Em 2012, a empresa construiu o Painel de Gestão de Sustentabilidade, que permite o acompanhamento detalhado pelo Comitê Executivo das diversas iniciativas, ligadas à sustentabilidade, desenvolvidas pelo banco. O Painel de Gestão foi formado com base nos três focos estratégicos e incorpora os aspectos apontados pelo DJSI e pelo ISE, como mecanismo para avaliar as áreas em que há avanços e outras que ainda exigem ações de melhoria, contribuindo com a evolução das agendas em cada área. (ITAÚ UNIBANCO, 2102)

A entrevistada E2 explica que o Painel de Gestão se alimenta de alguns critérios do DJSI, de alguns critérios do ISE e da própria Estratégia de Sustentabilidade. Esses inputs são cruzados com as prioridades do negócio e, a partir disso, são definidos os projetos que são considerados relevantes para serem trabalhados. Algumas vezes as questões são convergentes e, em outras, não. Por exemplo, Educação Financeira não impacta no DJSI e no ISE, porém, para o banco, é um ponto estratégico.

Dessa análise, surge o Painel de Projetos, com indicadores de desempenho vinculados a alguns indicadores internos e externos, como o GRI, que são utilizados para monitorar o andamento dos projetos. Esse processo se iniciou, quando a área de Sustentabilidade levou para o Comitê Executivo como estava a situação da empresa com relação ao DJSI, ao ISE e à estratégia de sustentabilidade. A partir disso, o Comitê Executivo instruiu que os projetos sejam alinhados com cada área de negócio. Então, os gestores de Sustentabilidade, em conjunto com os executivos das áreas, determinam o que deve ser feito, o que precisa ser melhorado e o que já está adequado, ou seja, o conjunto de projetos e iniciativas dentro das áreas que geram o Painel. Ou seja, funciona como um grande sinaleiro. Ele é trabalhado ao longo do ano e reportado ao Comitê Executivo duas vezes por ano.

A recente criação do Painel de Gestão mostra a preocupação da empresa, para que a sustentabilidade continue sendo incorporada nas diferentes áreas de negócio, e para que a avaliação dos resultados seja feita. Segundo Clarkson (1995), os dados passam a ser 
monitorados e gerenciados na medida em que a empresa atribui importância e relevância que justifique o acompanhamento. Além disso, quanto mais alto o nível de gestão ao qual os dados são reportados, maior o indício da importância atribuída ao tema.

\subsubsection{Compromissos e Pactos Voluntários}

Os principais compromissos e pactos voluntários assumidos pela empresa são:

Pacto Global - O banco aderiu ao Pacto em 2003 e, portanto, junto com o grupo de empresas participantes, comprometeu-se a adotar, em suas práticas de negócios, dez princípios básicos, nas áreas de direitos humanos, relações de trabalho, proteção ao meio ambiente e combate à corrupção. A empresa também integra o Comitê Brasileiro do Pacto Global.

Princípios do Equador - A empresa é signatária dos Princípios do Equador desde 2004. As instituições financeiras que decidem aderir, voluntariamente, aos Princípios do Equador comprometem-se a observar critérios socioambientais por eles estabelecidos em project finance com valor total igual ou superior a US\$ 10 milhões. Em 2011, o Banco foi reeleito para compor o Comitê Diretivo dos Princípios do Equador, sendo o único representante da América Latina nesse Comitê.

CDP - é uma iniciativa global que tem como objetivo reportar a investidores, os inventários de emissão de GEE de grandes corporações, informando sobre os riscos e as oportunidades ocasionados pelas mudanças do clima. A empresa é signatária e respondente do CDP no Brasil. Em 2008, tornou-se patrocinadora da expansão para a América Latina.

UNEP-FI - O Itaú Unibanco é signatário da UNEP-FI, parceria global entre o Programa das Nações Unidas para o Meio Ambiente e o setor financeiro, e participa da Task Force Latin America com o intuito de auxiliar a disseminação de seu conteúdo e das práticas de finanças sustentáveis para outras instituições financeiras.

Greenhouse Gas (GHG) Protocol - é o padrão internacional para gerenciar as emissões de GEE. A empresa utiliza a metodologia do GHG Protocol em seus inventários, e é membro fundador da iniciativa no Brasil. 
Pacto Nacional para Erradicação do Trabalho Escravo - A empresa é signatária do pacto desde 2008 e envolve sua cadeia de valor nos preceitos da iniciativa.

PRI - A Itaú Asset Management foi a primeira grande gestora de investimentos do Brasil a aderir aos Princípios, em 2008. Em 2010, o banco desenvolveu uma metodologia própria de análise para mapear aspectos que possam impactar o valor de mercado das empresas nas quais investe e, consequentemente, o desempenho dos ativos sob gestão.

Protocolo Verde - Iniciativa do Ministério do Meio Ambiente em parceria com a FEBRABAN que objetiva construir e implementar uma agenda comum em sustentabilidade, na indústria financeira, alinhada aos seus cinco princípios. A empresa assinou o acordo em 2009, quando o Protocolo foi criado.

Quadro 18 - Adesão do Itaú Unibanco às principais iniciativas voluntárias.

\begin{tabular}{|c|c|c|c|}
\hline Iniciativa & Descrição & $\begin{array}{l}\text { Ano de } \\
\text { Criação }\end{array}$ & $\begin{array}{c}\text { Ano de } \\
\text { Adesão } \\
\text { pelo Itaú } \\
\text { Unibanco }\end{array}$ \\
\hline Pacto Global & $\begin{array}{l}\text { Os signatários se comprometem a adotar, em suas } \\
\text { práticas de negócios, dez princípios básicos, nas } \\
\text { áreas de direitos humanos, relações de trabalho, } \\
\text { proteção ao meio ambiente e combate à corrupção. }\end{array}$ & 2000 & 2003 \\
\hline $\begin{array}{l}\text { Princípios do } \\
\text { Equador }\end{array}$ & $\begin{array}{l}\text { Diretrizes socioambientais utilizadas pelas } \\
\text { instituições financeiras signatárias em } \\
\text { financiamentos acima de US\$10 milhões. }\end{array}$ & 2003 & 2004 \\
\hline CDP & $\begin{array}{c}\text { Tem como objetivo reportar a investidores os } \\
\text { inventários de emissão de GEE de grandes } \\
\text { corporações. }\end{array}$ & 2000 & 2006 \\
\hline UNEP-FI & $\begin{array}{l}\text { Criado para promover a integração de todas as } \\
\text { recomendações sobre aspectos ambientais em } \\
\text { operações e serviços do setor financeiro. }\end{array}$ & 1992 & 2008 \\
\hline $\begin{array}{l}\text { GHG Protocol } \\
\text { Brasil }\end{array}$ & $\begin{array}{l}\text { Metodologia criada para elaborar inventário de } \\
\text { emissões de GEE. }\end{array}$ & 2008 & 2008 \\
\hline $\begin{array}{l}\text { Pacto Nacional } \\
\text { para Erradicação } \\
\text { do Trabalho } \\
\text { Escravo }\end{array}$ & $\begin{array}{l}\text { Reúne empresas brasileiras e multinacionais que } \\
\text { assumiram o compromisso de não ter trabalho } \\
\text { escravo em toda sua cadeia de valor. }\end{array}$ & 2005 & 2008 \\
\hline PRI & $\begin{array}{c}\text { Tem como objetivo estabelecer critérios sociais, } \\
\text { ambientais e de governança corporativa na tomada } \\
\text { de decisão de investimentos. }\end{array}$ & 2006 & 2008 \\
\hline Protocolo Verde & $\begin{array}{l}\text { Acordo assinado entre FEBRABAN e Ministério do } \\
\text { Meio Ambiente, estabelece que os bancos } \\
\text { signatários se comprometam a desenvolver critérios } \\
\text { socioambientais para seus financiamentos e a } \\
\text { promover linhas de crédito diferenciadas para } \\
\text { projetos com responsabilidade socioambiental. }\end{array}$ & 2009 & 2009 \\
\hline
\end{tabular}

FONTE: Baseado em ITAÚ UNIBANCO, 2012. 
A adesão a iniciativas voluntárias, resumidas no Quadro 18, mostra uma preocupação do Banco em ir além das exigências legais. No Brasil, os bancos não sofrem grandes pressões com relação aos impactos socioambientais de suas operações. Por exemplo, com relação à legislação ambiental, o setor bancário não é objeto de atenção prioritária por parte dos órgãos reguladores. Isso ocorre, provavelmente, pelo fato de suas atividades não terem grande impacto direto sobre o meio ambiente, como setores de geração de energia elétrica, mineração, papel e celulose e químico.

A empresa poderá se beneficiar por atuar além de suas obrigações legais em questões de RSC, pois ocupará uma posição privilegiada em um cenário em que as atividades estarão mais regulamentadas, conforme defendido por Madariaga e Cremades (2010). Husted e Salazar (2006) também defendem que a sociedade e a empresa se beneficiam mais quando a empresa usa a RSC de forma proativa do que quando é coagida a fazer tais investimentos. A entrevistada E1 concorda com essa visão ao afirmar que a pior maneira de adotar essas práticas é porque a lei mandou ou, efetivamente, porque houve um problema.

\subsubsection{Prêmios e reconhecimentos recebidos}

Nos últimos anos, a empresa recebeu prêmios e reconhecimentos, dentro e fora do país, por suas práticas voltadas à RSC. Em 2012, a empresa integrou pela sexta vez consecutiva o Guia Exame de Sustentabilidade, que reconhece as 20 organizações consideradas modelo em RSC no Brasil. A empresa também ficou na primeira posição do ranking de Transparência em Sustentabilidade das Empresas do IBOVESPA, em 2010. Outro exemplo foi a décima oitava colocação no ranking internacional Top 1000 Sustainable Companies, sendo a empresa brasileira mais bem colocada. A lista é organizada pela consultoria americana Justmeans, líder mundial em soluções para negócios sustentáveis.

Em 2011, o Itaú Unibanco foi eleito o banco mais sustentável do mundo pelo prêmio Sustainable Finance Awards, do Financial Times e IFC. Aspectos essenciais, apontados pela comissão julgadora para a concessão do prêmio ao Banco, foram: análise socioambiental como ferramenta estratégica na gestão de risco e na análise de investimentos, produtos inclusivos, como microcrédito e crédito universitário, e o foco no cliente.

É importante ressaltar que, após o Itaú Unibanco fazer uma ampla comunicação do prêmio em 
2011, O Conselho Nacional de Autorregulamentação Publicitária (CONAR) determinou a reformulação do comercial em que a empresa informa ao público ter sido premiada como "banco mais sustentável do mundo". Para o CONAR, a afirmação foi muito forte e impactante para ser veiculada sem o devido esclarecimento sobre os critérios usados na definição. Os conselho concluiu que as informações sobre a referida premiação não foram suficientemente esclarecidas, o que levou à recomendação de que a campanha fosse reformulada, caso a instituição financeira decidisse por sustentar o slogan. O banco tirou a campanha publicitária do ar. (CONTRAF, 2011)

A entrevistada E1 comenta o prêmio:

\begin{abstract}
Não existe o banco mais sustentável. Eu acho que estou no caminho. Isso (o prêmio) é um sinal. Não tem como ser hoje, porque você não tem nem ferramenta. O que tem é um compromisso de, cada vez mais, em cada um dos seus processos, incorporar essas novas variáveis para poder seguir em frente [...] Não existe um selo de sustentabilidade, perfeição. Existe um comprometimento e uma capacidade de avaliar se o que você está dizendo ou fazendo ou se propondo é o adequado e o esperado para você.
\end{abstract}

As principais informações que serviram como critérios utilizados para o prêmio estão disponíveis no relatório de sustentabilidade do banco, porém o público em geral não acessa os relatórios. Além disso, o conceito de sustentabilidade ainda não é completamente compreendido pela maior parcela da população. Essa barreira foi abordada por McWilliams et al. (2006), que acreditam que é muito dificil para os consumidores avaliarem as operações internas da empresa e as informações, contidas nos relatórios anuais, podem ser vistas como enviesadas, uma vez que são filtradas pelos gestores da própria empresa.

\title{
4.3.9 Investimentos Sociais e Culturais
}

Além dos focos estratégicos, a empresa atua em algumas "causas" sociais e ambientais. O Banco declara que, para atingir seu propósito de ser um agente de transformação e de buscar a performance sustentável, investe em ações voltadas para o desenvolvimento da sociedade. (ITAÚ UNIBANCO, 2012)

As causas em que a empresa atua são: educação pública; valorização e divulgação da arte 
nacional; apoio ao esporte em modalidades que retratam traços da identidade cultural brasileira. A empresa acredita que nessas áreas há oportunidade para aplicar as tecnologias e competências que foram desenvolvidas pelo Banco. (ITAÚ UNIBANCO, 2012)

Em 2012, os investimentos sociais e culturais realizados alcançaram o valor de $\mathrm{R} \$ 197,5$ milhões. Para a área de educação e cultura foram destinados $\mathrm{R} \$ 71,3$ milhões. Outros $\mathrm{R} \$ 15,9$ milhões foram investidos por meio da lei Rouanet em 11 estados brasileiros, e mais $\mathrm{R} \$ 4,5$ milhões foram empregados de acordo com as diretrizes da lei de Incentivo ao Esporte. (ITAÚ UNIBANCO, 2012)

É importante ressaltar que os investimentos sociais e culturais são gerenciados, principalmente, pela Fundação Itaú Social, pelo Instituto Unibanco e pelo Instituto Itaú Cultural. As três instituições são independentes e atuam com recursos humanos e financeiros próprios. Por esse motivo, esses investimentos não foram abordados em profundidade pelo presente estudo.

\subsection{Síntese dos Principais Resultados}

O Quadro 19 traz uma síntese dos principais resultados encontrados na pesquisa de campo, com base nas questões investigativas, as quais estão divididas nas dimensões analisadas no presente estudo, conforme mostrado anteriormente. 
Quadro 19 - Síntese dos principais resultados.

\begin{tabular}{|c|c|c|}
\hline Dimensão & Questões Investigativas & Resultados \\
\hline \multirow{3}{*}{$\begin{array}{l}\text { Responsabilidade } \\
\text { Social } \\
\text { Corporativa } \\
\text { (RSC) }\end{array}$} & Definição de RSC. & $\begin{array}{l}\text { Manutenção dos negócios no curto, médio e longo } \\
\text { prazo para uma entrega perene de valor às partes } \\
\text { interessadas. }\end{array}$ \\
\hline & Questões que envolvem a RSC. & $\begin{array}{l}\text { Todas as questões que envolvem problemas sociais e } \\
\text { ambientais, internos e externos à organização. }\end{array}$ \\
\hline & Públicos aos quais a RSC se dirige. & $\begin{array}{l}\text { Todos os stakeholders da empresa: acionistas, } \\
\text { funcionários, sociedade e governo. }\end{array}$ \\
\hline \multirow{4}{*}{$\begin{array}{l}\text { Desempenho } \\
\text { Social } \\
\text { Corporativo } \\
\text { (DSC) }\end{array}$} & $\begin{array}{l}\text { Forma como a organização } \\
\text { responde às questões de RSC. }\end{array}$ & $\begin{array}{l}\text { Proativa - antecipa as questões, faz mais do que o } \\
\text { exigido por lei. }\end{array}$ \\
\hline & Atividades e processos realizados. & $\begin{array}{l}\text { a) Avaliação de projetos com a perspectiva } \\
\text { socioambienatal; b) Avaliação sistemática de } \\
\text { despesas; c) Redução de desperdícios, otimização de } \\
\text { recursos e sinergia entre as atividades operacionais; d) } \\
\text { Educação Financeira para funcionários, clientes e não } \\
\text { clientes; e) Inclusão da variável socioambiental no } \\
\text { crédito, investimentos e novos produtos e serviços; f) } \\
\text { Criação de canais de comunicação com funcionários, } \\
\text { clientes e sociedade. }\end{array}$ \\
\hline & $\begin{array}{l}\text { Informações utilizadas para a } \\
\text { escolha das atividades e processos. }\end{array}$ & $\begin{array}{l}\text { a) Paineis, workshops e pesquisas com stakeholders } \\
\text { internos e externos; b) Práticas utilizadas no mercado; } \\
\text { c) Indicadores dos índices de sustentabilidade: ISE e } \\
\text { DJSI. }\end{array}$ \\
\hline & Envolvimento das áreas funcionais. & $\begin{array}{l}\text { Por meio das quatro frentes viabilizadoras: a) } \\
\text { Governança e Gestão; b) Incentivos; c) Eficiencia; d) } \\
\text { Cultura. }\end{array}$ \\
\hline \multirow{5}{*}{$\begin{array}{l}\text { Alinhamento } \\
\text { entre RSC e } \\
\text { Estratégia } \\
\text { Organizacional }\end{array}$} & $\begin{array}{l}\text { Inserção da RSC na formulação da } \\
\text { Estratégia Organizacional. }\end{array}$ & $\begin{array}{l}\text { a) Conceito de performance sustentável inserido na } \\
\text { visão; b) Escolha dos focos estratégicos; c) Criação da } \\
\text { Política de Sustentabilidade; d) Criação da } \\
\text { Governança de Sustentabilidade; e) Participação da } \\
\text { área de Sustentabilidade em outras instâncias do } \\
\text { banco, como o Comitê de Excelência do Atendimento, } \\
\text { o Comitê de Risco Socioambiental e o Comitê de } \\
\text { Avaliação de Processos e Produtos. }\end{array}$ \\
\hline & $\begin{array}{l}\text { Vínculo das práticas sociais com a } \\
\text { atividade principal da empresa. }\end{array}$ & $\begin{array}{l}\text { Os três focos estratégicos (Educação Financeira; } \\
\text { Riscos e Oportunidades Socioambientais; Diálogo e } \\
\text { Transparência) possuem vínculo com a atividade } \\
\text { principal. }\end{array}$ \\
\hline & $\begin{array}{l}\begin{array}{l}\text { Disseminação } \\
\text { organização. }\end{array} \\
\text { orgar }\end{array}$ & Por meio da espiral da performance sustentável. \\
\hline & $\begin{array}{l}\text { Forma de avaliação dos resultados } \\
\text { - utilização de modelo ou sistema } \\
\text { de indicadores para avaliação do } \\
\text { Desempenho Social. }\end{array}$ & Painel de Gestão - indicadores do GRI, ISE, DSJI. \\
\hline & $\begin{array}{l}\text { Nível organizacional ao qual os } \\
\text { resultados são reportados. }\end{array}$ & luas vezes $\mathrm{p}$ \\
\hline
\end{tabular}




\section{CONSIDERAÇÕES FINAIS}

As discussões acerca da definição de RSC, suas teorias e suas implicações no desempenho dos negócios continuarão. As questões centrais da RSC, tais como: para que serve um negócio e qual a contribuição deste para a sociedade, são tão antigas quanto os negócios em si. As ideias de Milton Friedman, que afirmou que a única responsabilidade social da empresa é gerar lucros para seus acionistas, ainda são defendidas por alguns acadêmicos. Porém, no meio empresarial, principalmente, em grandes empresas, a ideia de que a organização deve se preocupar com seu Desempenho Social, e não somente com o Desempenho Financeiro, parece estar estabelecida. A questão levantada agora é como incorporar as questões socioambientais nos negócios, pois ainda há muitas barreiras enfrentadas por falta de ferramentas e metodologia para implantar, medir e avaliar tais questões.

É interessante notar que temas como contratação de minorias, preocupação com o meio ambiente, contribuição com educação e artes, revitalização urbana, relatórios contábeis claros, propagandas não enganosas, produtos sem defeitos, atendimento a reclamações de consumidores e garantias, que foram apontados como relevantes em pesquisa realizada em 1970, apresentada no referencial teórico, continuam representando desafios para as empresas, sociedade e governo. Isso é um indicativo de que houve pouco avanço na solução dos problemas sociais e ambientais. As questões que parecem ter mais avançado, no Brasil, são propagandas não enganosas, produtos com defeito e garantias, provavelmente, devido ao surgimento de leis mais rigorosas.

Embora o setor financeiro não possua um alto impacto socioambiental direto, seu impacto indireto, por meio de suas atividades de investimento e financiamento, é grande. Os bancos têm o papel de controlar os fluxos financeiros, fazendo que tenham grande poder de influência. Por meio de suas decisões de investimentos e financiamentos, os bancos são capazes de promover mudanças no comportamento de empresas de todos os portes e setores. Portanto, o principal papel dos bancos não é de executor de mudanças, mas sim de indutor de mudanças nas partes com as quais se relaciona.

O estudo de campo foi realizado no Itaú Unibanco que, em 2011, ganhou o prêmio de "banco mais sustentável do mundo", pelo Financial Times e IFC. O poder de influência do banco pode ser percebido pelo dado de que a cada quatro reais movimentados no Brasil, um passa 
pelo Itáu Unibanco. Além disso, a empresa possui aproximadamente 40 milhoes de clientes, mais de 100 mil forncecedores e 1,1 trilhões de recursos próprios e livres, o que representa um terço do PIB brasileiro.

A realização do estudo de campo mostrou que os responsáveis pelo pensamento estratégico da empresa reconhecem a importância da RSC e promovem alterações em suas estratégias, modificando suas visões de longo prazo, estruturas organizacionais e práticas de negócios, com o objetivo de melhor incorporar o tema.

Atulamente, a RSC é abordada, pelo Itaú Unibanco, por meio do conceito de sutentabilidade, que para a empresa significa "a manutenção dos negócios no curto, médio e longo prazo para uma entrega perene de valor às partes interessadas". Portanto, para a empresa, sustentabilidade é, principalmente, a sustentabilidade dos seus negócios, porém reconhece que, para isso, é preciso atender também às expectativas e demandas de seus stakeholders, para que os mesmos mantenham relações de longo prazo com a empresa.

A partir da fusão entre Itaú e Unibanco, iniciou-se um processo de alinhamento do tema com a Estratégia. O banco colocou em sua nova visão a palavra sustentável, por meio do conceito de performance sustentável, que também se refere a performance perene dos negócios do banco, porém gerando valor compartilhado para a empresa e seus stakeholders. Além disso, o posicionamento com relação à RSC mudou de uma abordagem feita a partir de oito temas considerados prioritários - Transparência e Governança; Satisfação dos Clientes; Critérios Socioambientais; Diversidade; Mudanças Climáticas; Educação Financeira; Microfinanças; Engajamento de Stakeholders - para uma abordagem que foca em três temas considerados estratégicos - Educação Financeira, Riscos e Oportunidades Socioambientais e Diálogo e Transparência.

O banco criou frentes viabilizadoras - Governança e Gestão, Incentivos, Eficiência e Cultura como forma de difundir os conceitos por toda a organização. Os resultados da incorporação da sustentabilidade pelas áreas passaram ser avaliados a partir de um Painel de Gestão e reportados ao Comitê Executivo. Mudanças nas estruturas da organização também foram observadas, com a criação do Comitê de Sustentabilidade e de grupos que discutem as questões de acordo com temas de interesse. A empresa procura divulgar o seu conceito de sustentabilidade para seus colaboradores, por meio, principalmente, da espiral da performance 
sustentável, apesar disso ser um grande desafio em uma organização com mais de 100 mil funcionários.

Portanto, foi possível identificar que a empresa buscou alinhar a RSC com a sua Estratégia por meio do diálogo com seus stakeholder, para entender suas necessidades e demandas; da escolha de questões ligadas à sua atividade principal e fundamentais para o setor em que atua; do envolvimento das áreas; do envolvimento da alta gestão; do monitoramento e comunicação de resultados. O banco adota uma postura proativa, buscando antecipar as mudanças e evitando que, no futuro, possa ser obrigada a praticar tais medidas. Dessa forma, a empresa acredita que poderá obter benefícios gerados pela RSC como: licença para operar, aprendizagem, inovação e ganhos de reputação, conforme levantado na fundamentação teórica.

Por meio da coleta de dados secundários, encontrou-se que outros bancos brasileiros também se destacam por suas práticas de RSC e são reconhecidos, mudialmente, por meio de prêmios e reconhecimentos em relatórios de instituições que trabalham com o tema. Um aspecto que pode ser importante para o destaque do setor nesse campo é o fato de disporem de recursos para fazerem tais investimentos, uma vez que o setor bancário apresenta altos lucros no país. Conforme apresentado na fundamentação teórica, a maioria das empresas consultadas em pesquisa do IPEA apontou que o principal motivo que dificulta ou impede o desenvolvimento de ações sociais é a falta de dinheiro.

Outro fator que pode incentivar a relevância da RSC para os bancos é o cenário existente no país de altas taxas de juros e má situação financeira de grande parte da papulação. Além disso, o setor financeiro brasileiro possui uma imagem bastante negativa diante dos consumidores, muito associada aos vultosos lucros, aos níveis de spreads bancários praticados muito acima de padrões internacionais e ao fato de, continuamente, constar no topo das listas de reclamações de clientes por atendimento pouco satisfatório ou cobrança de taxas desconhecidas.

De qualquer forma, a RSC vem ganhando espaço na academia, nas empresas e nos governos. Conforme o aumento do desenvolvimento econômico do país, a demanda por RSC parece crescer e as leis relativas ao tema, conforme mostrado na fundamentação teórica, tendem a ser 
mais rigorosas. Portanto, as empresas que antecipam as questões e buscam alinhar a RSC à sua Estratégia, provavelmente, ocuparão uma posição privilegiada no longo prazo.

O presente estudo buscou responder como é feito o alinhamento entre RSC e Estratégia Organizacional, por meio da revisão da literatura sobre o tema e da pesquisa de campo em empresa em que o fenômeno pode ser observado. $\mathrm{O}$ estudo contribui com a formação do constructo de RSC e com a distinção entre os conceitos de RSC e sustentabilidade. Além disso, contribui para ampliar o conhecimento sobre as implicações estratégicas da RSC e da complexa relação entre Desempenho Financeiro e Desempenho Social. A pesquisa apontou algumas barreiras para gestão das questões socioambientais. A principal delas é a falta de conhecimento e ferramentas práticas.

A principal limitação do estudo é sua natureza exploratória, que não possibilita generalização dos resultados encontrados. Outra limitação importante é o viés da pesquisadora ao realizar a coleta e análise dos dados. Porém, essa limitação foi reduzida por meio da tringulação dos dados coletados.

Para estudos futuros recomenda-se que o processo seja investigado em empresas menores e de outros setores, com menos recursos disponíveis. Recomendam-se também estudos que verifiquem a percepção dos consumidores com relação às práticas de RSC adotadas pela empresa, o que poderia determinar a maior ou menor possibilidade de geração de benefícios. 


\section{REFERÊNCIAS}

ABBAGnANO, N. Dicionário de Filosofia. Tradução Alfredo Bosi. 3 ed. São Paulo: Martins Fontes, 1998.

ARTHUR D. LITTLE. The Business Case for Corporate Responsibility. Beacon Press, 2003. Disponível em http://www.bitc.org.uk/resources/publications/cr_business_case.html. Acesso em $12 / 03 / 2012$.

ASHLEY, A. P. Ética e Responsabilidade Social nos Negócios. São Paulo: Saraiva, 2003.

BACKHAUS, K.B.; STONE, B.A.; HEINER, K. Exploring the relationship between corporate social performance and employer attractiveness. Business \& Society, v.41, n.3, p. 292-318, 2002.

BANCO CENTRAL DO BRASIL; UNIETHOS. Políticas e Práticas socioambientais nas instituições financeiras, $2011 . \quad$ Disponível http://www.bcb.gov.br/pre/microfinancas/Workshop_RSAnasIFs_01.12.2011_SP.PDF.

Acesso em 01/03/2013.

BANCO CENTRAL DO BRASIL 2012 - BCB. Disponível em http://www.bcb.gov.br/ptbr/paginas/default.aspx. Acesso em 15/12/2012.

BANKTRACK; AMIGOS DA TERRA. Introdução ao setor bancário e suas práticas de sustentabilidade, $2012 . \quad$ Disponível em http://www.banktrack.org/manage/ems_files/download/introducao_ao_setor_bancario_brasile iro_e_suas_praticas_de_sustentabilidade/121219_brasil_setor_bancario_e_sustentabilidade_2 012_12_0.pdf. Acesso em 05/03/2013.

BARNEY, J. Strategic Factor Markets: Expectations, Luck, and Business Strategy. Management Science, v. 32, p. 1231-1241, 1986.

BARNEY, J. Firm resources and sustained competitive advantage. Journal of Management, v. 17, n. 1, p. 99-120, 1991.

BARON, D. Private politics, corporate social responsibility and integrated strategy. Journal of Economics and Management Strategy, v. 10, p. 7-45, 2001.

BEATO, R. S.; SOUZA, M. T. S.; PARISOTTO, I. R. S. Rentabilidade dos Índices de Sustentabilidade Empresarial em Bolsas de Valores: Um Estudo do ISE/BOVESPA. Revista de Administração e Inovação, v. 6, n. 3, 2009.

BIROU, A. Dicionário de ciências sociais. Tradução Alexandre Gaspar et al. 2 ed. Lisboa: Publicações Dom Quixote, 1976.

BLACK, T. Doing quantitative research in the social sciences: an integrated approach to research design, measurement and statistics. Sage, 1999.

BOLSA DE VALORES DE SÃO PAULO - BM\&FBOVESPA. Índice de Sustentabilidade $\begin{array}{llll}\text { Empresarial, } & 2012 . & \text { Disponível em }\end{array}$ 
http://www.bmfbovespa.com.br/Indices/download/Apresentacao-ISE.pdf. Acesso em $15 / 01 / 2012$.

BRANCO, M.C.; RODRIGUES, L.L. Corporate Social Responsibility and Resource-Based Perspectives. Journal of Business Ethics, v. 69, n. 2, p. 111-132, 2006.

BUCHHOLTZ, A.K.; CARROLL, A.B. Business and Society. 7 ed. Cengage Learning: Canadá, 2009.

BURKE, L.; LOGSDON, J.M. How corporate social responsibility pays off. Long Range Planning, v.29, p. 495-502, 1996.

CARROLL, A.B. A Three-Dimensional Conceptual Model of Corporate Social Performance. Academy of Management Review, v. 4, n. 4, p. 497-505, 1979.

CARROLL, A.B. The pyramid of corporate social responsibility: Toward the moral management of organizational stakeholders. Business Horizons, v.34, issue 4, p.39-48, 1991.

CARROLL. A. B. Corporate social responsibility: evolution of a definitional construct. Business and Society, v. 8, n.3, p. 268-295, 1999.

CARROLL, A. B. A history of corporate social responsibility: concepts and practices. In: CRANE, A.; McWILliAMS, A.; MATTEN, D.; MOON, J.; SIEGEL, D. The Oxford Handbook of Corporate Social Responsibility. New York: Oxford University Press, 2008.

CHANDLER, A. Strategy and structure. MA: MIT Press, 1962.

CHRISTMANN, P. Effects of "Best Practices" of Environmental Management on Cost Advantage: The Role of Complementary Assets. Academy of Management Journal, v. 43, p. 663-680, 2000.

CLARKSON, M. B. A Stakeholder Framework for Analyzing and Evaluating Corporate Social Performance. Academy of Management Review, v. 92, p. 105-108, 1995.

CONFEDERAÇÃO NACIONAL DOS TRABALHADORES DO RAMO FINANCEIRO CONTRAF. Conar obriga Itaú a retirar propaganda de banco mais sustentável do mundo. Contraf, 2011. Disponível em http://www.contrafcut.org.br/noticias.asp?CodNoticia=28448

CORREA P. R. R.; de Paula, L.F.R.; Oreiro, J.L.C.; Basílio, F.A.C. A Estrutura do Setor Bancário Brasileiro e o Ciclo Recente de Expansão do Crédito: O Papel dos Bancos Públicos. In: XXXVIII Encontro Nacional de Economia, ANPEC, 2010. Anais...Salvador: ANPEC, 2010.

CRANE, A.; MCWILLIAMS, A. MATTEN, D. MOON, J. SIEGEL, D. The Corporate Social Responsibility Agenda. In: The Oxford Handbook of Corporate Social Responsibiliy. New York: Oxford University Press, 2008.

DAVIS, K. Can business afford to ignore Social Responsibilities? California Management Review, v. 2, spring, p.70-76, 1960. 
DAVIS, K. Five Propositions for Social Responsibility. Business Horizons, n. 18, n. 3, p. 1924, 1975.

DeBAKKER, G.A. GROENWEGEN,P. DEN HOND,F. A Bibliometric analysis of 30 years of research and theory on Corporate Social Responsibility and Corporate Social Performance. Business and Society, v. 44, n.3, p. 283-317, 2005.

DIERICKX, I.; COOL, K. Asset Stock Accumulation and Sustainability of Competitive Advantage. Management Science, v. 35, p. 1504-1511, 1989.

EIBERT, H.; PARKET, I.R. The current status of Corporate Social Responsibility. Business Horizon, v. 16, aug, p. 5-14, 1973.

EISENHARDT, K. M. Building Theories from Case Study Research. The Academy of Management Review, v. 14, n. 4, p. 532-550, 1989.

EISENHARDT, K. M. Dynamic capabilities: What are they? Strategic Management Journal, v. 21, p. 1105-1121, 2000.

ELKINGTON, J. Cannibals With Forks: the triple bottom line of 21st century business. Oxford: Capstone Publishing, 1997.

FEDDERSEN, T.; GILLIGAN, T. Saints and markets: activists and the supply of credence goods. Journal of Economics and Management Strategy, v.10, p. 149-71, 2001.

FOMBRUN, C.; SHANLEY, C. What's in a name? Reputation building and corporate strategy. Academy of Management Review, v.33, n. 2, p. 233-258, 1990.

FOMBRUN, C; GARDBERG, N. A.; BARNETT, M.L. Opportunity Platforms and Safety Nets: Corporate Citizenship and Reputational Risk. Business and Society Review, v. 105, n. 1, p. 85-106, 2000.

FREDERICK, W. C. The growing concern over Business Responsibility. California Management Review, v. 29, p.99-114, 1960.

FREEMAN, R. E. Strategic Management: a stakeholder approach. Boston: Pitman, 1984.

FRIEDMAN, M. The social responsibility of business is to increase its profits. New York Times Magazine, v. 13, 1970.

GARRIDA, E.; MELÉ, D. Corporate Social Responsability Theories: Mapping the Territory. Journal of Business Ethics, v. 53, n. 1-2, p. 51-71, 2004.

GLOBAL REPORTING INITIATIVE - GRI. Disponível em https://www.globalreporting.org/languages/Portuguesebrazil/Pages/default.aspx. Acesso em 15/07/2012.

GOMES, A.; MORETTI, S. A Responsabilidade e o social: uma discussão sobre o papel das empresas. São Paulo: Saraiva, 2007. 
GRANT, R. M. The Resource-Based Theory of Competitive Advantage. California Management Review, v. 33, n. 3, p. 114-135, 1991.

GRUPO DE INSTITUTOS FUNDAÇÕES E EMPRESAS - GIFE. O investimento Social Privado, 2012. Disponível em http://www.gife.org.br/ogife_investimento_social_privado.asp. Acesso em 23/07/2012.

GVCES - CENTRO DE ESTUDOS EM SUSTENTABILIDADE - EAESP. Disponível em <http://www.gvces.com.br/index.php?r=site/conteudo\&id=1>. Acesso em: 11 nov. 2012.

HAMMOND, A., ADRIAANSE, A., RODENBURG, E., BRYANT, D., WOODWARD, R. Environmental Indicators: A Systematic Approach to Measuring and Reporting on Environmental Policy Performance in the Context of Sustainable Development. World Resources Institute, Washington, DC, 50 pp. Disponível em http://pdf.wri.org/environmentalindicators_bw.pdf. Acesso em 10/04/2012

HARRISON, J. S. Administração Estratégica de recursos e relacionamentos. Porto Alegre: Bookman, 2005.

HART, S. L. A Natural-Resource-Based View of the Firm. Academy of Management Review, v. 20, p. 986-1014, 1995.

HART, S. L. Beyond Greening: Strategies for a Sustainable World. Harvard Business Review, v. 75(1): p. 66, 1997.

HART, S. L; DOWELL, G. A. Natural-Resource-Based View of the Firm: Fifteen Years After. Journal of Management, v. 37, n.5, p. 1464-1479, 2011.

HUSTED, B.W. A contingency theory of corporate social performance. Business and Society, v. 39, n.1, p.24-48, 2000.

HUSTED, B. W.; ALLEN, D. B. Toward a model of corporate social strategy formulation. In: Social Issues in Management Division, Academy of Management Conference, August, 2001.

HUSTED, B. W; SALAZAR, J.D.J. Taking Friedman seriously: maximizing profits and social performance. Journal of Management Studies, v. 43, n. 1, p. 75-91, 2006.

INSTITUTO BRASILEIRO DE ANÁLISES SOCIAIS E ECONÔMICAS - IBASE. Balanço Social, 2012. Disponível em http://www.ibase.br/pt/2011/07/balanco-social/ Acesso em 20/04/2012.

INSTITUTO DE PESQUISAS ECONÔMICAS APLICADAS - IPEA. A iniciativa privada e o espírito público: a evolução da ação social das empresas privadas no Brasil, Brasília, 2006. Disponível em http://www.ipea.gov.br/acaosocial/IMG/pdf/doc-44.pdf. Acesso em 20/07/2012.

INSTITUTO ETHOS. Disponível em http://www3.ethos.org.br. Acesso em 23/07/2012. 
INSTITUTO NACIONAL DE METROLOGIA, QUALIDADE E TECNOLOGIA INMETRO. Responsabilidade Social. $\quad$ Diponível em http://www.inmetro.gov.br/qualidade/responsabilidade_social/. Acesso em 20/04/2012.

INTERNATIONAL FINANCE CORPORATION - IFC. Banking on Sustainability: Financing Environmental and Social Opportunities in Emerging Markets, Washington, 2007.

INTERNATIONAL ORGANIZATION FOR STANDARDIZATION - ISO. Disponível em http://www.iso.org/iso/home.html. Acesso em 20/04/2012.

ITAÚ UNIBANCO. Relatório Anual de Sustentabilidade 2008. Disponível em http://www.itauunibanco.com.br/relatoriodesustentabilidade/pt-br/anexos/. Acesso em $01 / 02 / 2013$.

ITAÚ UNIBANCO. Relatório Anual de Sustentabilidade 2009. Disponível em http://ww13.itau.com.br/PortalRI/HTML/port/infofinan/ra/2009/itau_unibanco_RA_2009.pdf. Acesso em 01/02/2013.

ITAÚ UNIBANCO. Relatório Anual de Sustentabilidade 2010. Disponível em http://www.itauunibanco.com.br/relatoriodesustentabilidade/2010/download/Itau-UnibancoRA-2010.pdf. Acesso em 01/02/2013.

ITAÚ UNIBANCO. Relatório Anual de Sustentabilidade 2011. Disponível em http://www.itauunibanco.com.br/relatoriodesustentabilidade/2011/RAS_2011.pdf. Acesso em 01/02/2013.

ITAÚ UNIBANCO. Relatório Anual de Sustentabilidade, 2012. Disponível em http://www.itauunibanco.com.br/relatoriodesustentabilidade/2012/pt/downloads/ItauUnibanco -RA2012.pdf. Acesso em 01/02/2013.

JENSEN, M.C; MECKELING, W. H. Theory of Firm: Managerial Behaviour, Agency Costs and Owner-ship Structure. Journal of Financial Economics, v.3, n.4, p. 305-360, 1976

JONES, M.T. Corporate Social Responsibility Revisited, Redefined. California Management Review, v.22, n.2, p. 59-67, 1980.

JONES, M.T. Missing the forest for the trees: A critique of the Social Responsibility concept and discourse. Business and Society. v. 35, n. 1, p. 7-41, mar.1996.

KARNANI, A. Doing Well by Doing Good: The Grand Illusion. California Management Review, v. 53, n. 2, p. 69-86, Winter 2011.

KING, A. A.; LENOX, M. J. Does It Really Pay to Be Green?: An Empirical Study of Firm Environmental and Financial Performance. Journal of Industrial Ecology, v. 5, n.1, p. 105116, 2001.

KPMG. International Survey of Corporate Responsibility Reporting, 2011. Disponível em < http://www.kpmg.com/PT/pt/IssuesAndInsights/Documents/corporateresponsibility2011.pdf >. Acesso em: 15/03/2012. 
KUHN, T.S. A estrutura das revoluções científicas. Tradução: Beatriz Vianna Boeira e Nelson Boeira. Editora Perspectiva: São Paulo, 1975.

KURUCZ, E.C. The business case for corporate social responsibility. In: CRANE, A.; McWILliamS, A.; MATTEN, D.; MOON, J.; SIEGEL, D. The Oxford Handbook of Corporate Social Responsibility. New York: Oxford University Press, 2008.

LAZONICK, W.; O'SULLIVAN, M. Maximizing Shareholder Value: A New Ideology for Corporate Governace. Economy and Society, v. 29, n. 1, p.13-35, 2000.

LOCKETT, A.; MOON, J.; VISSER, W. Corporate Social Responsibility in Management Research: Focus, Nature, Salience and Sources of Influence. Journal of Management Studies, v. 43, n. 1, p. 115-36, 2006.

MADARIAGA, J.G.; CREMADES, F.R. Corporate social responsibility and the classical theory of the firm: Are both theories irreconcilable? Innovar Journal, v.20, n.37, 2010.

MAGALHÃES, R.S. Lucro e reputação: interações entre bancos e organizações sociais na construção das políticas socioambientais. Tese (Doutorado em Ciência Ambiental) Programa de Pós-Graduação em Ciência Ambiental da Universidade de São Paulo, 2010.

MARCONDES, A.W.; BACARJI, C.D. ISE - Sustentabilidade no Mercado de Capitais. São Paulo: Report Editora, 2010.

MARTIN, R. L. The virtue Matrix: calculating the return on Corporate Responsibility. Harvard Business Review, v.80, n. 3, p. 68-75, 2002.

MATTEN, D.; CRANE, A. Corporate Citizenship: Towards an Extended Theoretical Conceptualization. Academy of Management Review, v. 30, n. 1, p.166-179, 2005.

McWILLIAMS, A.; SIEGEL, D. S. Corporate social responsibility: a theory of the firm perspective. Academy of Management Review, v. 26, n. 1, p. 117-127, 2001.

McWILliAMS, A.; SIEGEL, D. S; WRIGHT, P.M. Corporate Social Responsibility: Strategic Implications. Journal of Management Studies, v. 43, n.1, p. 1-18, 2006.

McWILlIAMS, A.; SIEGEL, D. S. Creating and Capturing Value: Strategic Corporate Social Responsibility, Resource-Based Theory, and Sustainable Competitive Advantage. Journal of Management, v. 37, n. 5, p. 1480-1495, 2011.

MICHALOS, A. Issues for business ethics in the nineties and beyond. Journal of Business Ethics, v. 16, n.3, p.219-231, 1997.

MINTZBERG, H. The case for corporate social responsibility. Journal of Business Strategy, v. 4, p. 3-15, 1983.

MOLTENI, M. The social-competitive innovation pyramid. Corporate Governance, v. 6, n. 4, 2006. 
NASCIMENTO, L. F.; LEMOS, A.D.C.; MELLO, M.C.A. Gestão Socioambinetal Estratégica. Porto Alegre: Bookman, 2008.

NORMAN, W.; MACDONALD, C. Getting to the Bottom of "Triple Bottom Line". Business Ethics Quarterly, Vol. 14, issue 2, p. 243-262, 2004.

ORGANISATION FOR ECONOMIC CO-OPERATION AND DEVELOPMENT - OECD. Handbook on Constructing Composite Indicators: Methodology and user guide. 2008. Disponível em <http://www.oecd.org/std/leadingindicatorsandtendencysurveys/42495745.pdf> Acesso em 22/09/2012.

ORLITZKY, M.; SCHMIDT, F.L.; RYNES, S.L. Corporate Social and financial performance: a meta-analysis. Organization Studies, v.24, n.3, p. 403-441, 2003.

PENROSE, E. The theory of the growth of the firm. New York: Wiley, 1959.

PENSAMENTO NACIONAL DAS BASES EMPRESARIAIS - PNBE. Disponível em http://www.pnbe.org.br. Acesso em 23/07/2012.

PESSOA, R.W.A.; NASCIMENTO, L.F.; NEVES, J.A.D.; OLIVEIRA FILHO, G.S. Estratégia e vantagem competitiva da responsabilidade social empresarial. Gestão \& Regionalidade, v.25, n.74, p.79-93, 2009.

PETERAF, M.A. The cornerstones of competitive advantage: A resource-based view. Strategic Management Journal, vol. 14, Issue 3, p. 179-191, 1993.

PORTER M. E.; LINDE, V. D. Toward a New Conception of the Environmental Competitiveness Relationship. Journal of Economic Perspectives, v. 9, n. 4, p. 97-118, 1995.

PORTER, M.E. What is strategy? Harvard Business Review, nov-dec, p. 61-78, 1996.

PORTER, M. E.; KRAMER, M. R. The competitive advantage of corporate philanthropy. Harvard Business Review, v. 80, n. 12, p. 57-68, 2002.

PORTER, M. E.; KRAMER, M. R. Strategy and society: the link between competitive advantage and corporate social responsibility. Harvard Business Review, v. 84, n. 12, p. 7892, 2006.

PRAHALAD, C. K.; HAMEL, G. The Core Competence of the Corporation. Harvard Business Review, v. 68, n. 3, p. 79-91, 1990.

REINHARDT, F. L. Environmental product differentiation: Implications for corporate strategy. California Management Review, v. 49, p. 43-73, 1998.

REIS, M. M.; VERAS, M. A. M.; CORRAR, L. J. Desempenho do Índice de Sustentabilidade Empresarial (ISE) da Bolsa de Valores de São Paulo. Universo Contábil, v. 5, n. 2, p. 24-38, 2009. 
RUSSO, M. V.; FOUTS, P. A. A Resource-Based Perspective on Corporate Environmental Performance and Profitability. Academy of Management Journal, v. 40, n. 3, p. 534-559, 1997.

SILVA, L. S. A.; QUELHAS, O. L. G. Sustentabilidade Empresarial e o Impacto no Custo de Capital Próprio das Empresas de Capital Aberto. Gestão e Produção, v. 13, n. 3, p. 385-395, 2006.

STAKE, R. E. Case Studies. In: DENZIN, N. K.; LINCOLN, Y. S. (Org.). Handbook of qualitative research. Thousand Oaks: Sage Publications, p. 435-454, 1994.

SURROCA, J.; TRIBÓ, J.A.; WADDOCK, S. Corporate responsibility and financial performance: the role of intangible resources. Strategic Management Journal, v. 31, Issue 5, p. 463-490, 2010.

SWARTZ, M.S.; CARROLL, A.B. Corporate Social Responsibility: A three Domain Approach. Business Ethics Quarterly, v. 13, n. 4, p. 503-530, 2003.

TACHIZAWA, T. Gestão Ambiental e Responsabilidade Social Corporativa: estratégias de negócios focadas na realidade brasileira. São Paulo: Atlas, 2002.

WADDOCK, S.A.; GRAVES, S. 'The corporate social performance - financial performance link', Strategic Management Journal, v. 18, n. 4, p. 303-319, 1997.

WADDOCK, S.A. Parallel universes: companies, academics, and the progress of corporate citizenship. Business and Society Review, v. 109, n.1, p. 5-42, 2004.

WERNERFELT, B. A Resource-Based View of the Firm. Strategic Management Journal, v. 5, p. 171-180, 1984.

WOOD, D.J. Corporate Social Performance Revisited. Academy of Management Review, n. 16, p. 66-73, 1991.

WOOD, D.J; LOGSDON, J.M. Business Citizenship: From individuals to Organizations'. Business Ethics Quarterly, special issue on Ethics and Entrepreneurship, n. 3, p.59-94, 2002.

YIN, R. K. Estudo de Caso: planejamento e métodos. 4 ed. Tradução: Ana Thorell. Porto Alegre: Bookman, 2010.

ZYGLIDOPOULOS, S.C. The impact of accidents on firm's reputation for social performance. Business \& Society, v. 40, n. 4, p. 416-441, 2001. 


\section{APÊNDICE 1 - ROTEIRO DAS ENTREVISTAS}

1) Dados do entrevistado

a) Nome

b) Cargo

c) Área

d) Tempo na área

e) Tempo na empresa

2) O que você acredita que seja RSC?

3) Qual é a responsabilidade social do Itaú Unibanco?

4) Há uma definição formalizada sobre RSC?

5) O entendimento da empresa sobre RSC é difundido por toda a organização? Caso sim, de que forma?

6) A quais públicos a empresa considera que a RSC se dirige? (interno, externo, ambos)

7) Quais questões a organização considera que a RSC envolve?

8) Como a empresa responde/se posiciona em relação a essas questões? (reativa, defensiva, acomodada, proativa)

9) Em relação às práticas de RSC:

- Quais práticas são realizadas?

- Quais critérios são utilizados para a escolha?

- Quais informações são utilizadas?

- Quem define as práticas (qual nível organizacional)?

- Como as áreas funcionais da empresa estão envolvidas nessas práticas?

- Como é feita a avaliação dos resultados?

- Qual nível organizacional está envolvido?

- A que nível organizacional são reportadas?

10) A RSC está inserida formalmente na estratégia da organização?

11) Como os líderes da organização lidam com o tema?

12) É utilizado algum modelo ou sistema de indicadores para elaboração de relatórios de RSC como o GRI, Balanço Social etc.? Caso positivo, quais?

13) Quais são as principais dificuldades encontradas para a gestão das questões socioambientais? 